University of Wollongong

Research Online

Australian Institute for Innovative Materials -

Papers

Australian Institute for Innovative Materials

$1-1-2019$

\title{
G-C3N4-based films: A rising star for photoelectrochemical water splitting
}

Liqun Wang

Tianjin Normal University

Yueyu Tong

University of Wollongong, yt932@uowmail.edu.au

Jianmin Feng

Tianjin Normal University

Jungang Hou

Dalian University of Technology

Jing Li

Tianjin Normal University

See next page for additional authors

Follow this and additional works at: https://ro.uow.edu.au/aiimpapers

Part of the Engineering Commons, and the Physical Sciences and Mathematics Commons

Research Online is the open access institutional repository for the University of Wollongong. For further information contact the UOW Library: research-pubs@uow.edu.au 


\title{
G-C3N4-based films: A rising star for photoelectrochemical water splitting
}

\begin{abstract}
Graphitic carbon nitride (g-C3N4), as a new type of polymeric semiconductor, has been regarded as a promising photoelectrode material for efficient photoelectrochemical (PEC) water splitting for hydrogen production due to its suitable band structure for water splitting reaction, certain range of visible-light absorption, non-toxicity, low cost, and good stability. However, there are many obstacles impeding the further application of g-C3N4 material in PEC water splitting, such as its wide band gap, low electrical conductivity, high recombination rate of photogenerated electrons/holes, and the difficulty in fabrication of high-quality g-C3N4 films on substrates. In this view, we summarize the novel bottom-up technology for achieving the high-quality g-C3N4 films. Moreover, the modification strategies of enhancement on PEC performance of $\mathrm{g}-\mathrm{C} 3 \mathrm{~N} 4$ film photoelectrodes, including functional groups introducing, heteroelements doping, and composite films designing, have been discussed in detail. At last, the key challenges and possible solutions for future development on g-C3N4-based PEC water splitting are concluded.

\section{Disciplines}

Engineering | Physical Sciences and Mathematics

Publication Details

Wang, L., Tong, Y., Feng, J., Hou, J., Li, J., Hou, X. \& Liang, J. (2019). G-C3N4-based films: A rising star for photoelectrochemical water splitting. Sustainable Materials and Technologies, 19 e00089-1-e00089-20.
\end{abstract}

\section{Authors}

Liqun Wang, Yueyu Tong, Jianmin Feng, Jungang Hou, Jing Li, Xinggang Hou, and Ji Liang 


\section{g- $\mathrm{C}_{3} \mathrm{~N}_{4}$-based Films: a Rising Star for Photoelectrochemical Water Splitting}

Abstract: Graphitic carbon nitride $\left(\mathrm{g}-\mathrm{C}_{3} \mathrm{~N}_{4}\right)$, as a new type of polymeric semiconductor, has been regarded as a promising photoelectrode material for efficient photoelectrochemical (PEC) water splitting for hydrogen production due to its suitable band structure for water splitting reaction, certain range of visible-light absorption, non-toxicity, low cost, and good stability. However, there are many obstacles impeding the further application of $\mathrm{g}-\mathrm{C}_{3} \mathrm{~N}_{4}$ material in PEC water splitting, such as its wide band gap, low electrical conductivity, high recombination rate of photogenerated electrons/holes, and the difficulty in fabrication of high-quality $g-\mathrm{C}_{3} \mathrm{~N}_{4}$ films on substrates. In this view, we summarize the novel bottom-up technology for achieving the high-quality $g-\mathrm{C}_{3} \mathrm{~N}_{4}$ films. Moreover, the modification strategies of enhancement on PEC performance of $\mathrm{g}_{-} \mathrm{C}_{3} \mathrm{~N}_{4}$ film photoelectrodes, including functional groups introducing, heteroelements doping, and composite films designing, have been discussed in detail. At last, the key challenges and possible solutions for future development on $\mathrm{g}-\mathrm{C}_{3} \mathrm{~N}_{4}$-based PEC water splitting are concluded.

Keywords: Graphitic carbon nitride; Film; Photoelectrochemistry.

\section{Background and Incentives}

In the past few decades, an unprecedented amount of energy has been consumed due to the rapid industrialization and population expansion. This energy demand is, however, still increasing at a continuously accelerated speed. To be specific, it is estimated that the global energy demand will be doubled by $2050[1,2]$. To make this scenario even worse, the present worldwide energy supply is mainly from fossil fuels, such as coal, oil, and natural gas [3], which have a limited reserve and can thus cause energy depletion in the near future. Meanwhile, the exploitation, transportation, and 
utilization of these fossil fuels are inevitably accompanied with the release of various toxic and/or green-house gases, including carbon-dioxide and nitrogen/sulfur oxides. These will collaboratively result in both energy crisis and environmental deterioration, which will finally impose a significant threaten to the sustainable development of society and even the survival of mankind [4].

Therefore, the harvest and utilization of more environment-friendly and renewable energies (so-called new energies) to replace the conventional fossil fuels have been regarded as the most fundamental, promising, and effective solution to tackle these issues. With the fast advance of science and technology, various types of new energies, such as solar energy [5], wind energy [6], wave energy [7], and hydrogen energy [8], have been wildly investigated and utilized. Among the various alternative new types of energy, hydrogen energy, that is, the chemical energy stored in hydrogen gas, has been regarded as a very promising candidate due to its emission-free characteristics and relatively high energy density $\left(\sim 140 \mathrm{MJ} \mathrm{kg}^{-1}\right)$ [9]. Most of the hydrogen gas, however, is produced by steam reforming of methane in industry, which is energy-intensive, $\mathrm{CO}_{(2)}$-emitting, and low-efficient [10]. Besides, the as-produced hydrogen gas always contains $\mathrm{CO}$, which is poisonous to many catalysts and is hard to be completely removed, making such hydrogen gas unsuitable to be directly used for the state-of-the-art fuel cells and greatly limiting its applications. Alternatively, high-purity hydrogen gas can be produced by electrically splitting water. However, the water electrolysis always consumes a large amount of electricity. Specifically, in the actual water electrolysis process, an approximately $5 \mathrm{kWh}$ of electricity is required for the production of hydrogen gas of per cubic meter at one standard atmospheric pressure. In this case, a huge amount of electricity consumption may appear with the implementation of large-scale hydrogen generation from water electrolysis. Consequently, the more "green" and "sustainable" strategy to produce hydrogen gas at high purity is essential for the long-term development of 
hydrogen energy.

Since the discovery of hydrogen generation using a $\mathrm{TiO}_{2}$ photoelectrode under ultraviolet (UV) light radiation in 1972 [11], the photoelectrochemical (PEC) water splitting, which is able to directly split water into hydrogen gas and oxygen gas by utilizing the inexhaustible solar energy as the driving force, has become a research hotspot in materials science and new energy fields. Superior to the methane steam reformation process, the PEC water splitting can produce hydrogen gas at a higher purity, free of any $\mathrm{CO}$ or other impurities. Moreover, the PEC water splitting also behaves an inimitable advantage of lower electric energy consumption compared with electrochemical water electrolysis process. Therefore, the PEC water splitting for hydrogen generation shows a very great potential for solving both energy and environment crisis [12-16].

In a PEC water splitting system, the photoelectrode material is the core component, which plays an essential role by absorbing incident light and generating photogenerated electrons/holes to drive the water splitting reaction. So the structural and chemical characteristics of these materials fundamentally determine the actual water splitting pathway and the associated energy conversion efficiency. Up to now, a diverse range of materials have been utilized as photoelectrode materials for PEC water splitting, including oxides [17-22], sulfides [23-26], nitrides [27-29], and others.

To achieve an efficient utilization of solar energy, the photoelectrode materials should be able to absorb the visible light, which constitutes a large fraction ( $c a .43 \%)$ in the solar spectrum [3]. However, the traditional photoelectrode materials, such as $\mathrm{TiO}_{2}$, meet a bottleneck to match such absorption requirements due to their extremely wide band gaps (3.0-3.2 eV). In order to absorb as much visible light as possible, the semiconducting materials with narrower band gaps have been developed for PEC water splitting, which are mainly based on the highly toxic and unstable CdS and CdSe materials, making them hard to be practically deployed at a large scale [30-32]. On the 
basis of these considerations, seeking non-toxic, stable, and visible-light-driven photoelectrode materials has been a prerequisite and hotspot for future research on PEC water splitting.

Very recently, graphitic carbon nitride $\left(\mathrm{g}-\mathrm{C}_{3} \mathrm{~N}_{4}\right)$, a new type of polymeric semiconducting material, has triggered a worldwide interest as the next generation photoelectrode material for PEC water splitting, due to its suitable band structure, a certain range of visible-light absorption, non-toxicity, low cost, and high stability $[33,34] \cdot \mathrm{g}-\mathrm{C}_{3} \mathrm{~N}_{4}$ has a layered structure that resembles graphite. In each layer, the structural units are triazine $\left(\mathrm{C}_{3} \mathrm{~N}_{3}\right)$ (Figure 1a) and tri-s-triazine/heptazine $\left(\mathrm{C}_{6} \mathrm{~N}_{7}\right)$ rings (Figure 1b). The latter is regarded as the most energetically stable structure at the ambient condition, and thus it has been the mostly accepted building block of $\mathrm{g}-\mathrm{C}_{3} \mathrm{~N}_{4}[35,36]$.

For real application of $\mathrm{g}-\mathrm{C}_{3} \mathrm{~N}_{4}$ materials in PEC water splitting, acquiring $\mathrm{g}-\mathrm{C}_{3} \mathrm{~N}_{4}$ with film form instead of bulky or powdery structures is essential. During the PEC water splitting process, the photogenerared electrons (or holes) need to be gathered by conductive substrates, and transmitted to the opposite electrode via the outer circuit afterwards. However, the considerably large 3-dimensional (3D) sizes of bulk $\mathrm{g}-\mathrm{C}_{3} \mathrm{~N}_{4}$ will cause excessive consumptions/recombination of carriers, while those large interspaces among the $\mathrm{g}-\mathrm{C}_{3} \mathrm{~N}_{4}$ powder will block the transfer of carriers. Thus, this process is obviously impossible to proceed for those $\mathrm{g}-\mathrm{C}_{3} \mathrm{~N}_{4}$ materials with bulky and powdery structures. 


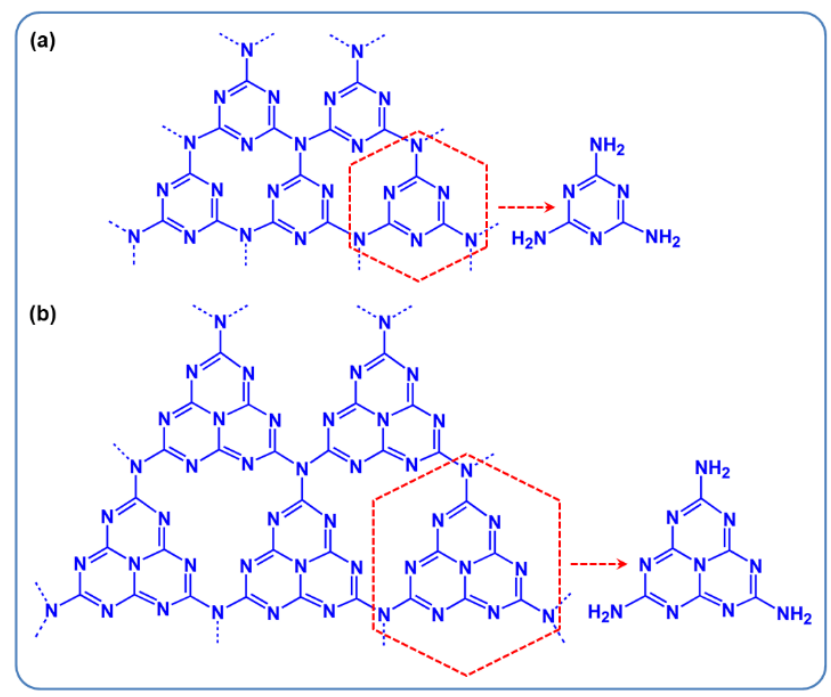

Figure 1 (1.5-column). Structure illustration of $\mathrm{g}_{-} \mathrm{C}_{3} \mathrm{~N}_{4}$ in (a) triazine and (b) tri-s-triazine/heptazine.

Up to now, hundreds of articles related to $\mathrm{g}-\mathrm{C}_{3} \mathrm{~N}_{4}$ films for PEC water splitting have been published. However, to the best of our knowledge, there have not been any comprehensive reviews available on this hot research topic except for one recent published mini-review [37]. This scenario thus makes it very necessary and urgent to provide a critical and comprehensive review to discuss the application of $\mathrm{g}-\mathrm{C}_{3} \mathrm{~N}_{4}$ films on PEC water splitting photoelectrodes in detail.

Herein, we focus on the latest advances in $\mathrm{g}-\mathrm{C}_{3} \mathrm{~N}_{4}$ films for PEC water splitting. Firstly, the principles of $\mathrm{g}-\mathrm{C}_{3} \mathrm{~N}_{4}$-based PEC water splitting, and the feasibility and challenge of $\mathrm{g}-\mathrm{C}_{3} \mathrm{~N}_{4}$ for PEC water splitting will be discussed. Subsequently, we will comprehensively summarize the different types of the $\mathrm{g}-\mathrm{C}_{3} \mathrm{~N}_{4}$ films as the PEC water splitting photoelectrodes according to their fabrication pathways and the modification methods of enhancement on PEC performance. Next, the g- $\mathrm{C}_{3} \mathrm{~N}_{4}$-based composite films and their application in PEC water splitting will be presented. Lastly, we conclude with the key challenges and opportunities in the future development of $\mathrm{g}_{-} \mathrm{C}_{3} \mathrm{~N}_{4}$-based films for PEC water splitting. We hope that this review will offer a valuable insight for g- $\mathrm{C}_{3} \mathrm{~N}_{4}$-based PEC water splitting. 


\section{Principle, Feasibility and Challenge of $\mathrm{g}-\mathrm{C}_{3} \mathrm{~N}_{4}$ as Photoelectrode Materials}

\subsection{Principle of PEC Water Splitting on a g- $\mathrm{C}_{3} \mathrm{~N}_{4}$-based Photoanode}

A typical PEC water splitting reaction takes place in a PEC water splitting cell, which has at least one photoelectrode for harvesting incident light [38-41]. Figure 2a shows the structural diagram of $\mathrm{g}-\mathrm{C}_{3} \mathrm{~N}_{4}$-based PEC water splitting cell, which is composed of a $\mathrm{g}_{-} \mathrm{C}_{3} \mathrm{~N}_{4}$-based photoanode and a counter electrode (cathode). These electrodes are usually immersed in an electrolyte (e.g. aqueous solution of $\mathrm{Na}_{2} \mathrm{SO}_{4}$ ), and connected by an outer circuit.

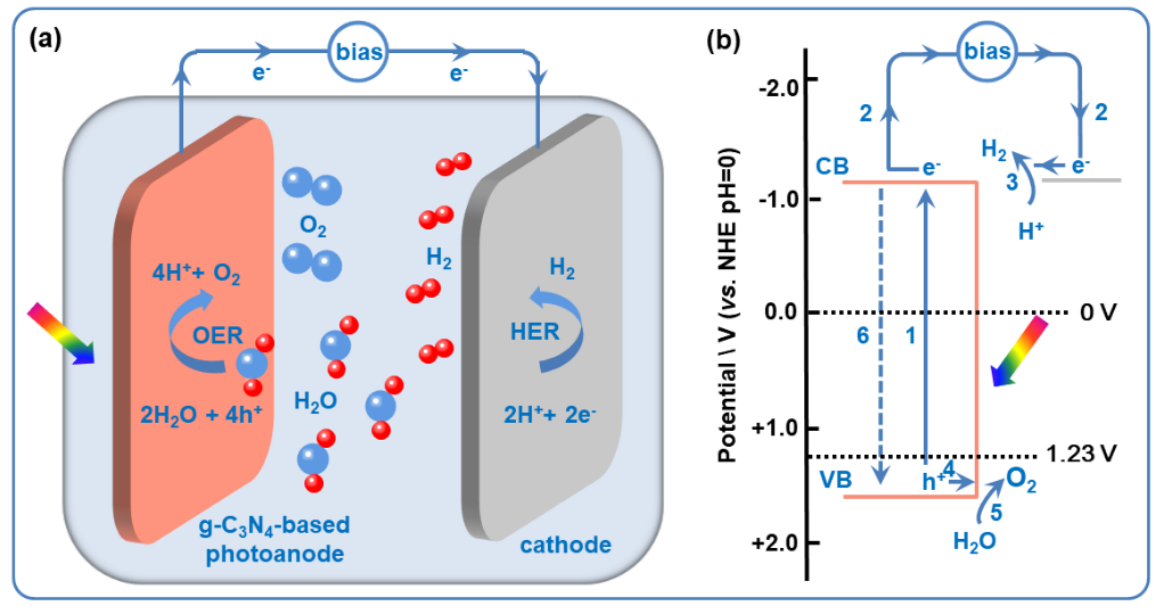

Figure 2 (2-column). Schematic illustration of (a) a PEC water splitting cell using a g- $\mathrm{C}_{3} \mathrm{~N}_{4}$-based photoanode as the working electrode, and (b) fractional steps of $\mathrm{g}-\mathrm{C}_{3} \mathrm{~N}_{4}$-based PEC water splitting process.

In the PEC water splitting process, the oxygen evolution reaction (OER) and hydrogen evolution reaction (HER) simultaneously happen on the surfaces of $\mathrm{g}-\mathrm{C}_{3} \mathrm{~N}_{4}$-based photoanode and cathode, respectively (Figure 2a). Specifically, when the incident light irradiates the photoanode, the electrons in the valence band (VB) of $\mathrm{g}-\mathrm{C}_{3} \mathrm{~N}_{4}$ are excited to the conduction band $(\mathrm{CB})$ to form photogenerated electrons, leaving positively charged holes in the VB (step 1 in Figure 2b). Subsequently, the photogenerated electrons transport from the photoanode to the cathode through the outer circuit (step 2 in Figure 2b), and then reduce the protons dissolved in the electrolyte and generate hydrogen gas (HER, step 3 in Figure 2b), as described in eq.1 [9]:

Cathode: $2 \mathrm{H}^{+}+2 \mathrm{e}^{-} \rightarrow \mathrm{H}_{2}, \quad E_{\text {red }}^{0}=0 \mathrm{~V}(1)$ 
where, $E_{\text {red }}^{\mathrm{o}}$ is $\mathrm{H}_{2}$ evolution potential [ $0 \mathrm{~V} v s$. normal hydrogen electrode (NHE) at $\mathrm{pH}=0$ ].

At the meantime, the holes left in the VB of $\mathrm{g}-\mathrm{C}_{3} \mathrm{~N}_{4}$ migrate from inside the photoanode to the surface (step 4 in Figure 2b), and oxidize water to produce oxygen gas (OER, step 5 in Figure 2b), as described in eq.2 [9]:

Photoanode: $2 \mathrm{H}_{2} \mathrm{O}+4 \mathrm{~h}^{+} \rightarrow 4 \mathrm{H}^{+}+\mathrm{O}_{2}, \quad E_{\mathrm{ox}}^{0}=1.23 \mathrm{~V} \mathrm{(2)}$

where, $E_{\mathrm{ox}}^{\mathrm{o}}$ is $\mathrm{O}_{2}$ evolution potential $(1.23 \mathrm{~V}$ vs. $\mathrm{NHE}$ at $\mathrm{pH}=0)$.

Apart from the ones that are respectively involved in the electrode reactions, the rest of the photogenerated electrons and holes, which fail to reach the photoelectrode surface in their migration process, will be recombined and neutralized (step 6 in Figure 2b).

\subsection{Feasibility and Challenge of $\mathrm{g}-\mathrm{C}_{3} \mathrm{~N}_{4}$ for PEC Water Splitting}

As an emerging photoelectrode material, $\mathrm{g}-\mathrm{C}_{3} \mathrm{~N}_{4}$ exhibits a series of outstanding features, such as its suitable energy band structure for water splitting reaction, visible-light absorption at a certain wavelength range, non-toxicity, low price, and high stability. To be specific, firstly, the edge of CB for $\mathrm{g}-\mathrm{C}_{3} \mathrm{~N}_{4}$ is about $-1.11 \mathrm{eV}$ vs. $\mathrm{NHE}$, lower than the $\mathrm{H}_{2}$ evolution potential. Meanwhile, its VB edge locates at approximately $1.57 \mathrm{eV} v s$. NHE, higher than the $\mathrm{O}_{2}$ evolution potential [42]. In this case, when $\mathrm{g}-\mathrm{C}_{3} \mathrm{~N}_{4}$ is excited by the incident light, it can produce the photogenerated electrons and holes with sufficient energy to drive the HER and OER on the surface of photoanodes and cathodes, respectively. Secondly, $\mathrm{g}-\mathrm{C}_{3} \mathrm{~N}_{4}$ has a visible-light-absorption up to $450 \mathrm{~nm}$, resulting from its band gap $\left(E_{\mathrm{g}}\right)$ of ca. $2.7 \mathrm{eV}$ [43]. This is a significant advantage compared with the traditional photoelectrode materials (e.g. $\mathrm{TiO}_{2}$ ) because the latter can only absorb the ultraviolet (UV) light. Thirdly, $\mathrm{g}-\mathrm{C}_{3} \mathrm{~N}_{4}$ consists of earth-abundant elements of carbon and nitrogen, and does not consist of any toxic and rare elements. Fourthly, g- $\mathrm{C}_{3} \mathrm{~N}_{4}$ can endure a high temperature up to $600{ }^{\circ} \mathrm{C}$ in air [44] and is stable in acid, alkali, and organic solvents [45]. Lastly, g- $\mathrm{C}_{3} \mathrm{~N}_{4}$ can be obtained through a very 
simple thermal polymerization from a diverse range of low-cost and nitrogen-rich precursors, such as melamine, urea, thiourea, and dicyandiamide [46, 47].

Apart from these, $\mathrm{g}-\mathrm{C}_{3} \mathrm{~N}_{4}$ nanosheets can also be obtained by exfoliating the bulky $g-\mathrm{C}_{3} \mathrm{~N}_{4}$. This provides additional opportunity to utilize the advantages of 2-dimensional (2D) nanostructure. Furthermore, the surface chemistry of $\mathrm{g}-\mathrm{C}_{3} \mathrm{~N}_{4}$ can be easily modified at the molecular level, due to its polymeric nature, which further facilitates the performance improvement by heteroelement doping or composition designing $[48,49]$. Owning to these desirable characteristics of $\mathrm{g}-\mathrm{C}_{3} \mathrm{~N}_{4}$, it has been regarded as one of the most promising photoelectrode materials for PEC water splitting.

In spite of these advantages, there are still a number of issues that impedes the further improvements of $\mathrm{g}_{-} \mathrm{C}_{3} \mathrm{~N}_{4}$-based PEC water splitting. On the one hand, the difficulty in the fabrication of $\mathrm{g}-\mathrm{C}_{3} \mathrm{~N}_{4}$ films on substrates is the main issue. As above-mentioned, for hydrogen generation from PEC water splitting, deposition of semiconducting materials onto substrates to form photoelectrodes in a film-structure is essential [50-58]. However, the $\mathrm{g}-\mathrm{C}_{3} \mathrm{~N}_{4}$ materials, which are often obtained through the thermal polymerization of various precursors (e.g. melamine, urea, or thiourea), are normally bulky monolith or powders [33-36, 45-49, 59-66]. To make things even worse, $\mathrm{g}-\mathrm{C}_{3} \mathrm{~N}_{4}$ is hard to be dispersed or dissolved in almost all the common solvents, making it very difficult to form a stable and homogeneous slurry to be made into a film with high quality (i.e., uniform, continuous, and good substrate adhesion) through the conventional methods, such as silk-screen printing, spin coating, and doctor blade. This significantly hinders the transport of photogenerated electrons, leading to poor PEC water splitting performance. On the other hand, some drawbacks in the intrinsic properties of $\mathrm{g}-\mathrm{C}_{3} \mathrm{~N}_{4}$ are also hindering the achievement of efficient PEC water splitting. For instance, although $\mathrm{g}-\mathrm{C}_{3} \mathrm{~N}_{4}$ shows the visible-light absorption, its maximal absorption wavelength of $\sim 450 \mathrm{~nm}$ is still insufficient for an efficient solar light harvesting. Besides, 
the low electrical conductivity and high recombination rate of photogenerated electrons/holes are still the obstacles that must be overcome in order to obtain a satisfactory PEC efficiency $[67,68]$.

In the recent years, significant breakthroughs in enhancing the performance of $\mathrm{g}-\mathrm{C}_{3} \mathrm{~N}_{4}$-based photoelectrodes for PEC water splitting have been achieved, including the novel bottom-up methods of preparing $\mathrm{g}-\mathrm{C}_{3} \mathrm{~N}_{4}$ films, introducing functional groups, doping heteroatoms, and constructing g- $\mathrm{C}_{3} \mathrm{~N}_{4}$-based composite films, etc. Regarding the bottom-up technologies, g- $\mathrm{C}_{3} \mathrm{~N}_{4}$ films can be in-situ deposited onto various substrates, usually resulting in a more homogeneous microstructure and intimate contact with substrates than those obtained by the conventional methods. Besides, modifying $\mathrm{g}-\mathrm{C}_{3} \mathrm{~N}_{4}$ films by functional groups or heteroatoms and constructing g- $\mathrm{C}_{3} \mathrm{~N}_{4}$-based composite films can not only improve the absorption in the visible light region but also increase the electronic conductivity of $\mathrm{g}-\mathrm{C}_{3} \mathrm{~N}_{4}$ and suppress the recombination of photogenerated electrons and holes. All of these are very important for the enhancement on g- $\mathrm{C}_{3} \mathrm{~N}_{4}$-based PEC water splitting performance. In the following sections, we will introduce the representative works and provide a summary of $\mathrm{g}-\mathrm{C}_{3} \mathrm{~N}_{4}$-based films as the key components in PEC water splitting process

\section{3. g- $\mathrm{C}_{3} \mathrm{~N}_{4}$ Films and Their PEC Water Splitting Performance}

\subsection{Fabrication, Structure, and Performance of g- $\mathrm{C}_{3} \mathrm{~N}_{4}$ Films}

For an efficient PEC water splitting process based on a $\mathrm{g}-\mathrm{C}_{3} \mathrm{~N}_{4}$ photoelectrode, a high-quality g- $\mathrm{C}_{3} \mathrm{~N}_{4}$ film on the substrate plays an essential role [69]. The $\mathrm{g}-\mathrm{C}_{3} \mathrm{~N}_{4}$ films that are obtained through the conventional top-down methods, however, usually show unsatisfactory PEC performances. Normally in these processes, the bulky $\mathrm{g}-\mathrm{C}_{3} \mathrm{~N}_{4}$ materials are prepared by thermal polymerization, with subsequent treatments to form particles or nanosheets by grinding or exfoliation, respectively. 
Finally, the $\mathrm{g}-\mathrm{C}_{3} \mathrm{~N}_{4}$ films are prepared on different substrates by the conventional filming technologies, such as silk-screen printing [70], spin coating [71], drop casting [72], dip casting [73], doctor blade [74], sol process [75], vacuum filtration [76], and electrophoretic deposition [77].

As aforementioned, due to the poor dispersibility/solubility of $\mathrm{g}-\mathrm{C}_{3} \mathrm{~N}_{4}$ in most solvents, it is very difficult to fabricate the uniform and stable slurry or sol, frequently resulting in large $\mathrm{g}-\mathrm{C}_{3} \mathrm{~N}_{4}$ aggregations and cracks in both the film and the interface between film and substrate. As a result, the $\mathrm{g}-\mathrm{C}_{3} \mathrm{~N}_{4}$ photoelectrodes exhibit the drawbacks of inhomogeneous microstructure and weak contact with substrates. Therefore, such top-down-prepared $\mathrm{g}-\mathrm{C}_{3} \mathrm{~N}_{4}$ film photoelectrodes often show a low PEC performance and a limited photocurrent density that is only several microampere per square centimeter [70-77], as summarized in the Table 1.

Table 1. The PEC water splitting performance of $\mathrm{g}_{-} \mathrm{C}_{3} \mathrm{~N}_{4}$ film photoelectrodes prepared by the top-down route.

\begin{tabular}{|c|c|c|c|c|c|c|}
\hline $\begin{array}{c}\text { Fabrication } \\
\text { method }\end{array}$ & g- $\mathrm{C}_{3} \mathrm{~N}_{4}$ form & $\begin{array}{c}\text { Photocurrent } \\
\text { density } \\
\left(\mu \mathrm{A} \mathrm{cm} \mathbf{c m}^{-2}\right)\end{array}$ & $\begin{array}{c}\text { Potential } \\
\text { (V) }\end{array}$ & Electrolyte & $\begin{array}{l}\text { Light } \\
\text { source }\end{array}$ & Ref. \\
\hline $\begin{array}{l}\text { silk-screen } \\
\text { printing }\end{array}$ & nanosheets & 0.92 & $\begin{array}{c}1.5 \\
\text { vs. } \mathrm{Ag} / \mathrm{AgCl}\end{array}$ & $0.1 \mathrm{M} \mathrm{Na}_{2} \mathrm{SO}_{3}$ & visible light & {$[70]$} \\
\hline spin coating & particles & 8.3 & $\begin{array}{c}0.6 \\
\text { vs. } \mathrm{Ag} / \mathrm{AgCl}\end{array}$ & $0.2 \mathrm{M} \mathrm{Na}_{2} \mathrm{SO}_{4}$ & $\begin{array}{c}30 \mathrm{~W} \\
\text { visible LED }\end{array}$ & [71] \\
\hline drop casting & particles & 0.75 & $\begin{array}{c}0.8 \\
\text { vs. } \mathrm{Ag} / \mathrm{AgCl}\end{array}$ & $0.1 \mathrm{M} \mathrm{KCl}$ & visible light & {$[72]$} \\
\hline dip casting & $\begin{array}{l}\text { nanoplates and } \\
\text { nanorods }\end{array}$ & $\begin{array}{c}3 \text { (nanoplates) } \\
4 \text { (nanorods) }\end{array}$ & N/A & $0.1 \mathrm{M} \mathrm{Na}_{2} \mathrm{SO}_{4}$ & visible light & {$[73]$} \\
\hline doctor blade & nanosheets & 0.2 & $\begin{array}{c}1.2 \\
\text { vs. } \mathrm{SCE}^{*}\end{array}$ & $0.05 \mathrm{M} \mathrm{Na}_{2} \mathrm{SO}_{4}$ & $\begin{array}{l}\text { visible light } \\
(\lambda>420 \mathrm{~nm})\end{array}$ & {$[74]$} \\
\hline sol process & particles & 8 & $\begin{array}{c}-0.2 \\
\text { vs. } \mathrm{Ag} / \mathrm{AgCl}\end{array}$ & N/A & $\begin{array}{l}\text { visible light } \\
(\lambda>420 \mathrm{~nm})\end{array}$ & {$[75]$} \\
\hline $\begin{array}{l}\text { vacuum } \\
\text { filtration }\end{array}$ & nanosheets & 0.5 & $\begin{array}{c}0.0 \\
v s . \mathrm{SCE}\end{array}$ & $0.5 \mathrm{M} \mathrm{Na}_{2} \mathrm{SO}_{4}$ & $\begin{array}{c}\text { solar } \\
\text { simulator }\end{array}$ & [76] \\
\hline $\begin{array}{c}\text { electrophoretic } \\
\text { deposition }\end{array}$ & particles & 1 & $\begin{array}{c}0.0 \\
\text { vs. } \mathrm{Ag} / \mathrm{AgCl}\end{array}$ & $1 \mathrm{M} \mathrm{KOH}$ & $\begin{array}{c}50 \mathrm{~W} \text { white } \\
\text { LED }(\lambda>410 \\
\mathrm{nm})\end{array}$ & {$[77]$} \\
\hline
\end{tabular}

${ }^{*} \mathrm{SCE}$ is saturated calomel electrode. 
In order to improve the PEC water splitting performance, novel bottom-up approaches have been developed to fabricate $\mathrm{g}-\mathrm{C}_{3} \mathrm{~N}_{4}$ films, including the thermal vapor condensation [78-82], microcontact-printing-assisted access [83], solvothermal route [84, 85], and direct growth [86, 87]. Different from the $\mathrm{g}-\mathrm{C}_{3} \mathrm{~N}_{4}$ films prepared by the conventional top-down routes, the $\mathrm{g}-\mathrm{C}_{3} \mathrm{~N}_{4}$ films obtained from the bottom-up approaches can be free of large $\mathrm{g}-\mathrm{C}_{3} \mathrm{~N}_{4}$ particles aggregations and cracks, resulting in a uniform microstructure, continuous coverage, and intimate contact with the substrate. This thus greatly facilitates the charge transfer, usually resulting in a better PEC water splitting performance. In this section, the synthesis, structure, and performance of $\mathrm{g}_{-} \mathrm{C}_{3} \mathrm{~N}_{4}$ films prepared by these bottom-up pathways will be illustrated in detail.

Thermal Vapor Condensation (TVC). The TVC method is a typical bottom-up route, in which a transformation from solid precursors to precursor vapors and then to the solid $\mathrm{g}-\mathrm{C}_{3} \mathrm{~N}_{4}$ is carried out to deposit $\mathrm{g}-\mathrm{C}_{3} \mathrm{~N}_{4}$ films on substrates. According to the different deposition procedures, TVC can be categorized into two types: the one-step and two-step TVC. In a one-step TVC procedure, the substrate is placed on top of a container that is filled with the nitrogen-rich precursors (Figure 3a). When the container is heated to a temperature that is higher than the sublimation point of precursors $\left(\sim 80-300{ }^{\circ} \mathrm{C}\right)$, the precursors vapor is generated, which then condenses on the substrate after reaching saturation in the container. When the temperature further increases to $550-600{ }^{\circ} \mathrm{C}$, the precursors, which has condensed on the substrate, are thermal polymerized to form a $\mathrm{g}-\mathrm{C}_{3} \mathrm{~N}_{4}$ film on the substrate [78]. In contrast to the direct formation of the $\mathrm{g}-\mathrm{C}_{3} \mathrm{~N}_{4}$ film in the one-step TVC, the two-step TVC includes two deposition procedures in sequence (Figure 3b). In the first deposition, g- $\mathrm{C}_{3} \mathrm{~N}_{4}$ is deposited on the inner wall of the reactor. Subsequently, a substrate is placed in the reactor; and $\mathrm{g}-\mathrm{C}_{3} \mathrm{~N}_{4}$ is vaporized and deposited again to form the $\mathrm{g}-\mathrm{C}_{3} \mathrm{~N}_{4}$ film on the surface of substrates in the second deposition [79]. 

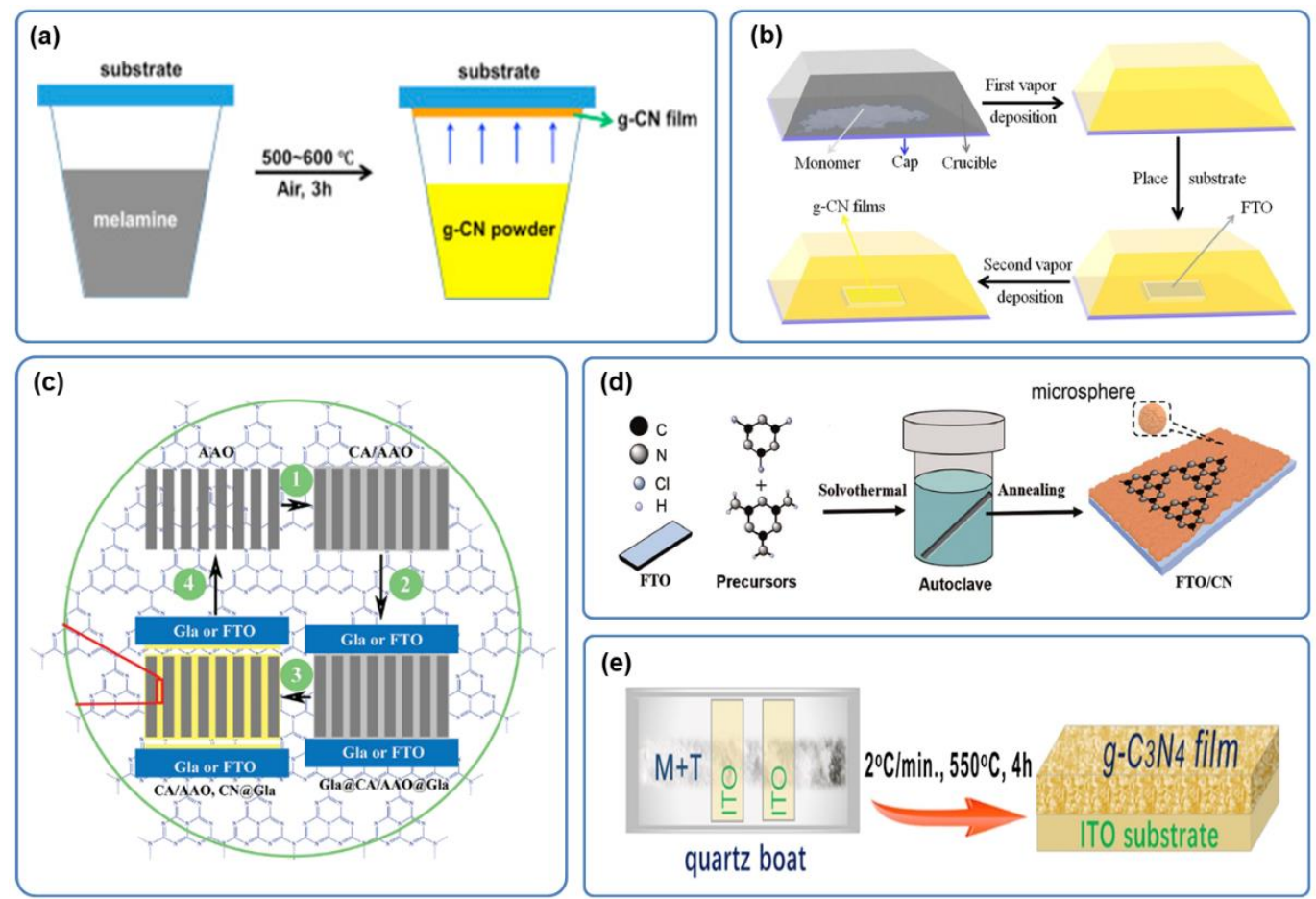

Figure 3 (2-column). Schematic illustration of (a) one-step TVC [78], (b) two-step TVC [79], (c) microcontact-printing-assisted access [83], (d) solvothermal route [84], and (e) direct growth [87] procedure for deposition of $\mathrm{g}-\mathrm{C}_{3} \mathrm{~N}_{4}$ films on substrates. Reprinted from refs. [78, 79, 83, 84, 87] with permission, respectively.

In the TVC approach to fabricate $\mathrm{g}-\mathrm{C}_{3} \mathrm{~N}_{4}$ films, the frequently used precursors to prepare bulky g- $\mathrm{C}_{3} \mathrm{~N}_{4}$, such as melamine [78, 80, 81], cyanamide [80], dicyanamide [79], thiourea [82], and urea [82], can also be utilized. Moreover, a wide variety of materials can be used as substrates for the g- $\mathrm{C}_{3} \mathrm{~N}_{4}$ films, including fluorine-doped tin oxide conducting glass (FTO) [78-82], indium-doped tin oxide conducting glass (ITO) [78], quartz glass [78], and silicon slice [78]. By tuning the preparation parameters, the morphology and microstructure of the films can be easily modified, from compact particle films (Figure 3a and b) [78], nanorod films (Figure 3c and d) [78] to framework structures (Figure 3e and f) [82]. 

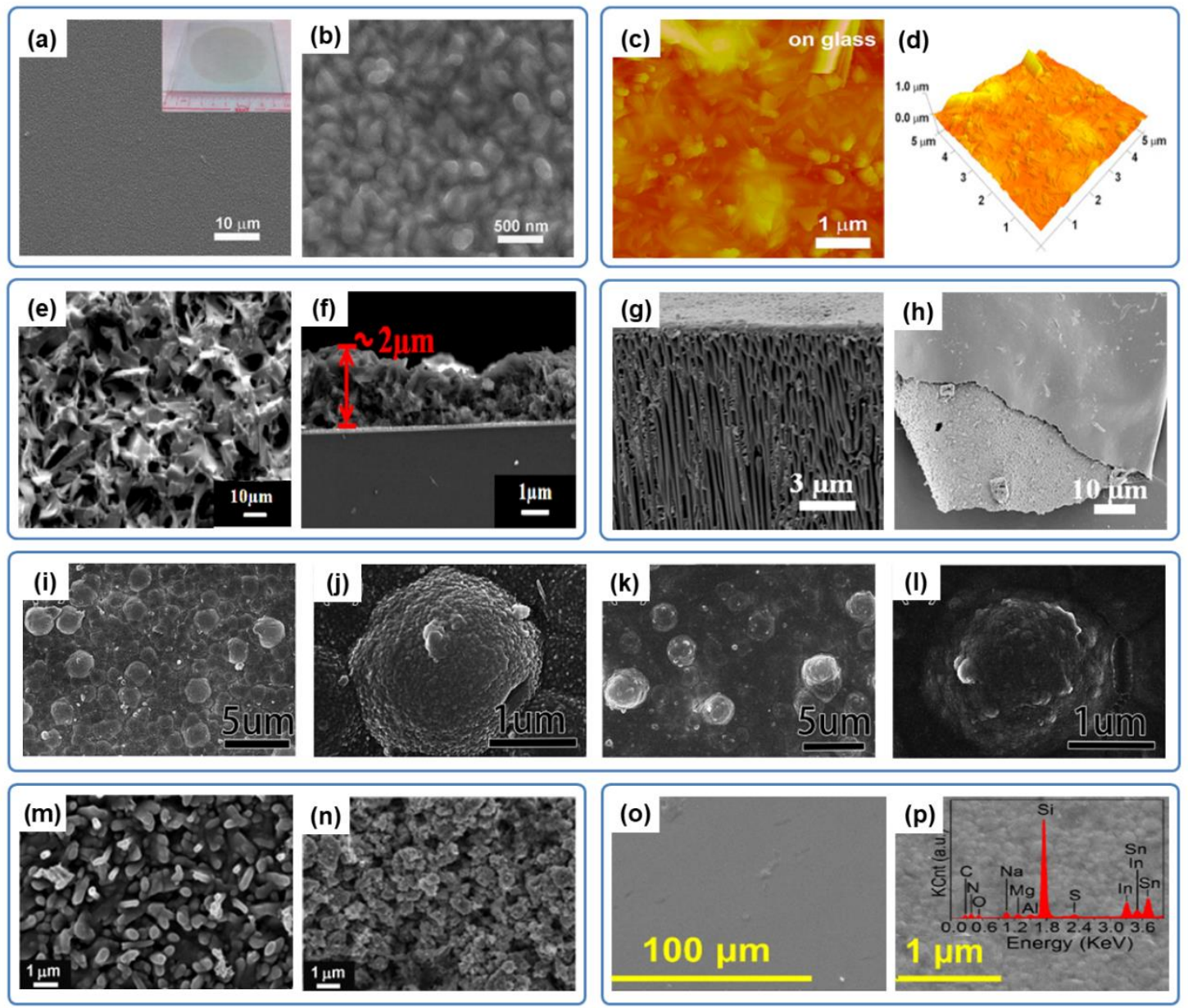

Figure 4 (2-column). SEM surface images of a compact particle $\mathrm{g}-\mathrm{C}_{3} \mathrm{~N}_{4}$ film obtained from TVC procedure in (a)

low- and (b) high-magnification. The inset in b shows the digital photo of the compact particle film. Atomic force microscope (AFM) images of (c) surface and (d) three dimensional morphologies for a $\mathrm{g}-\mathrm{C}_{3} \mathrm{~N}_{4}$ nanorod film prepared by TVC technology. Reprinted from refs. [78] with permission. SEM surface images of (e) top view and (f) cross-sectional view for a framework $\mathrm{g}-\mathrm{C}_{3} \mathrm{~N}_{4}$ film deposited through TVC process. Reprinted from ref. [82] with permission. SEM images of ( $\mathrm{g}$ ) cross-sectional view of a $\mathrm{g}-\mathrm{C}_{3} \mathrm{~N}_{4}$ film prepared by microcontact-printing-assisted access and (h) a flexible $\mathrm{g}-\mathrm{C}_{3} \mathrm{~N}_{4}$ film detached from its substrate. Reprinted from ref. [83] with permission. SEM images of a $\mathrm{g}-\mathrm{C}_{3} \mathrm{~N}_{4}$ film obtained from solvothermal route $(\mathrm{i}, \mathrm{j})$ before and $(\mathrm{k}, \mathrm{l})$ after post-annealing. Reprinted from ref. [84] with permission. SEM surface images of (m) a nanorod and (n) a porous g- $\mathrm{C}_{3} \mathrm{~N}_{4}$ film prepared by direct growth. Reprinted from refs. [86] with permission. SEM surface images of a compact g- $\mathrm{C}_{3} \mathrm{~N}_{4}$ film obtained from direct growth in (o) low- and (p) high-magnification. The inset in p shows 
the results of elemental analysis. Reprinted from refs. [87] with permission.

The $\mathrm{g}-\mathrm{C}_{3} \mathrm{~N}_{4}$ films prepared by TVC method can be utilized as the photoanodes in the PEC water splitting cells, and show significant performance enhancement. Specifically, the photocurrent densities (63-120 $\left.\mu \mathrm{A} \mathrm{cm}^{-2}\right)$ are not only higher than that generated by the photoanodes obtained from top-down approach (less than $10 \mu \mathrm{A} \mathrm{cm}$ ), but also show the greater advantage than the photoanodes prepared by other bottom-up approaches (3.5-30 $\mu \mathrm{A} \mathrm{cm}^{-2}$ ) (Table 2). Especially, the highest photocurrent density of $120 \mu \mathrm{A} \mathrm{cm} \mathrm{cm}^{-2}$ at $1.55 \mathrm{~V} v s$. reversible hydrogen electrode (RHE) is generated by the $\mathrm{g}-\mathrm{C}_{3} \mathrm{~N}_{4}$ photoanode [78]. Based on the above discussion, TVC has been regarded as a very convenient, versatile, and effective strategy to fabricate $\mathrm{g}-\mathrm{C}_{3} \mathrm{~N}_{4}$ films.

Table 2. The performance of PEC water splitting cells based on the $\mathrm{g}-\mathrm{C}_{3} \mathrm{~N}_{4}$ film photoelectrodes prepared by the bottom-up approach.

\begin{tabular}{|c|c|c|c|c|c|}
\hline $\begin{array}{l}\text { Fabrication } \\
\text { method }\end{array}$ & $\begin{array}{l}\text { Photocurrent density } \\
\qquad\left(\mu \mathrm{A} \mathrm{cm}^{-2}\right)\end{array}$ & $\begin{array}{c}\text { Potential } \\
\text { (V) }\end{array}$ & Electrolyte & Light source & Ref. \\
\hline \multirow{5}{*}{ TVC } & 120 & $\begin{array}{c}1.55 \\
v s . \mathrm{RHE}\end{array}$ & $\begin{array}{c}0.1 \mathrm{M} \mathrm{Na}_{2} \mathrm{SO}_{3} \text { and } \\
0.01 \mathrm{M} \mathrm{Na}_{2} \mathrm{~S}\end{array}$ & $\begin{array}{l}\text { solar simulator } \\
\left(\mathrm{AM} 1.5^{* *}\right)\end{array}$ & [78] \\
\hline & 63 & $\begin{array}{c}1.23 \\
v s . \mathrm{RHE}\end{array}$ & $0.1 \mathrm{M} \mathrm{Na}_{2} \mathrm{SO}_{4}$ & $\begin{array}{l}\text { solar simulator } \\
\quad(\mathrm{AM} 1.5)\end{array}$ & [89] \\
\hline & 100 & $\begin{array}{c}1.23 \\
v s . \mathrm{RHE}\end{array}$ & $\begin{array}{c}0.1 \mathrm{M} \mathrm{Na}_{2} \mathrm{SO}_{4}, 0.1 \mathrm{M} \\
\mathrm{Na}_{2} \mathrm{SO}_{3} \text { and } 0.01 \mathrm{M} \\
\mathrm{Na}_{2} \mathrm{~S}\end{array}$ & $\begin{array}{l}\text { solar simulator } \\
\quad(\mathrm{AM} 1.5)\end{array}$ & {$[80]$} \\
\hline & 75 & $\begin{array}{c}1.23 \\
v s . \mathrm{RHE}\end{array}$ & $\begin{array}{c}0.1 \mathrm{M} \mathrm{Na}_{2} \mathrm{SO}_{4}, 0.1 \mathrm{M} \\
\mathrm{Na}_{2} \mathrm{SO}_{3} \text { and } 0.01 \mathrm{M} \\
\mathrm{Na}_{2} \mathrm{~S}\end{array}$ & solar simulator & [81] \\
\hline & 89 & $\begin{array}{c}1.10 \\
v s . \text { RHE }\end{array}$ & $0.1 \mathrm{M} \mathrm{Na}_{2} \mathrm{SO}_{4}$ & $\begin{array}{l}\text { solar simulator } \\
\quad(\mathrm{AM} 1.5)\end{array}$ & {$[82]$} \\
\hline $\begin{array}{l}\text { microcontact- } \\
\text { printing-assisted } \\
\text { access }\end{array}$ & 30 & $\begin{array}{c}1.23 \\
v s . \mathrm{RHE}\end{array}$ & $0.1 \mathrm{M} \mathrm{Na}_{2} \mathrm{SO}_{4}$ & $\begin{array}{l}\text { solar simulator } \\
\quad(\mathrm{AM} 1.5)\end{array}$ & [83] \\
\hline \multirow{2}{*}{$\begin{array}{l}\text { solvothermal } \\
\text { route }\end{array}$} & 3.5 & $\begin{array}{c}1.23 \\
v s . \mathrm{RHE}\end{array}$ & $0.2 \mathrm{M} \mathrm{Na}_{2} \mathrm{SO}_{4}$ & $\begin{array}{l}\text { visible light } \\
(\lambda>420 \mathrm{~nm})\end{array}$ & [84] \\
\hline & 10 & $\begin{array}{c}1.23 \\
v s . \mathrm{RHE}\end{array}$ & $0.5 \mathrm{M} \mathrm{Na}_{2} \mathrm{SO}_{4}$ & $\begin{array}{l}\text { solar simulator } \\
\quad(\mathrm{AM} 1.5)\end{array}$ & {$[85]$} \\
\hline
\end{tabular}


${ }^{*} \mathrm{AM} 1.5$ is the 1.5 air mass, and the incident intensity is $100 \mathrm{~mW} \mathrm{~cm}{ }^{-2}$.

Microcontact-Printing-Assisted Access. A unique template-assisted method has been developed to deposit $\mathrm{g}-\mathrm{C}_{3} \mathrm{~N}_{4}$ films onto glasses or FTO substrates, which is similar to the microcontact-printing technology that is widely employed in electronic industry. Consequently, this method is named as microcontact-printing-assisted access (Figure 3c) [83]. In this method, an anodic aluminum oxide (AAO), an aqueous cyanamide solution, and two pieces of FTO (or glass slide) are used as the template, precursor, and substrates, respectively. Specifically, the cyanamide solution is infiltrated into the AAO membrane, and then the AAO is placed between two substrates. At a high temperature of $550{ }^{\circ} \mathrm{C}$, the cyanamide inside AAO is released and turned into vapor, which diffuses upward and downward simultaneously along each channel. Finally, the cyanamide vapor reaches the substrates and thermally polymerizes to form the $\mathrm{g}-\mathrm{C}_{3} \mathrm{~N}_{4}$ films.

The $\mathrm{g}-\mathrm{C}_{3} \mathrm{~N}_{4}$ films obtained from the microcontact-printing-assisted access possess a series of unique features: 1) the thickness of the $\mathrm{g}-\mathrm{C}_{3} \mathrm{~N}_{4}$ film can be easily controlled by changing the concentration of the aqueous cyanamide solution; 2) the films on the upper and lower substrates almost show the same quality, because the precursor is released from both sides of the channels of AAO and then condenses and polymerizes on both substrates; 3) the obtained $\mathrm{g}_{-} \mathrm{C}_{3} \mathrm{~N}_{4}$ film can partially inherit the periodic structure from AAO, which provides the possibility of fabricating an array of $\mathrm{g}-\mathrm{C}_{3} \mathrm{~N}_{4}$ nanorods (Figure $4 \mathbf{g}$ ); 4) flexible and self-supporting $\mathrm{g}-\mathrm{C}_{3} \mathrm{~N}_{4}$ films can be easily obtained upon removal of substrates, making this method especially feasible for flexible devices (Figure 4h). Moreover, the $\mathrm{g}-\mathrm{C}_{3} \mathrm{~N}_{4}$ photoanode obtained from this technology shows a basic satisfactory performance, and its photocurrent density can reach $\sim 30 \mu \mathrm{A} \mathrm{cm}{ }^{-2}$ at $1.23 \mathrm{~V} v s$. RHE 
(Table 2).

Solvothermal Route. The solvothermal route has been developed to prepare $\mathrm{g}-\mathrm{C}_{3} \mathrm{~N}_{4}$ films, and it usually includes two consecutive steps: solvothermal procedure and subsequent annealing treatment (Figure 3d) [84, 85]. In the solvothermal step, the growth of $\mathrm{g}-\mathrm{C}_{3} \mathrm{~N}_{4}$ film follows the Stranski-Krastanov mode. It begins with the 2D layer-by-layer mode (shorter than $12 \mathrm{~h}$ ), and then transits to a 3D micro-spheres stacking manner. After this solvothermal step (e.g. $\left.180{ }^{\circ} \mathrm{C} / 24 \mathrm{~h}\right)$, the g- $\mathrm{C}_{3} \mathrm{~N}_{4}$ film, which is composed of interconnected secondary microspheres $(2-3 \mu \mathrm{m})$ with primary nanoparticles of about a few nanometers, is obtained (Figure $\mathbf{4} \mathbf{i}$ and $\mathbf{j}$ ). The solvothermal treatment itself, however, can hardly provide sufficient kinetic energy to form a complete tri-s-triazine structure. As a result, a post-annealing treatment at $550{ }^{\circ} \mathrm{C}$ is necessary to improve the crystallinity of the $\mathrm{g}-\mathrm{C}_{3} \mathrm{~N}_{4}$ film for this method. Interestingly, after this annealing, the interfaces of microspheres and nanoparticles become indistinct, indicating that a thermal cross-linking and polymerization sequentially take place (Figure $\mathbf{4 k}$ and $\mathbf{l}$ ).

Using the solvothermal method, $\mathrm{g}-\mathrm{C}_{3} \mathrm{~N}_{4}$ films can be formed on various substrates, such as FTO [84, 85], glass [85], and $\mathrm{TiO}_{2}$ [85]. In addition, by changing the treatment time, precursor concentration, and post-annealing temperature, the thickness and density of the $\mathrm{g}_{-} \mathrm{C}_{3} \mathrm{~N}_{4}$ films can be controlled. Importantly, a covalent bond can be formed between the molecular precursors and the substrate surface during the solvothermal process, which results in a strong and intimate interfacial contact between them. In consequence, the adhesion between the $\mathrm{g}-\mathrm{C}_{3} \mathrm{~N}_{4}$ film and substrate can be enhanced, so does transportation of photogenerated electrons from the $\mathrm{g}-\mathrm{C}_{3} \mathrm{~N}_{4}$ film to the substrate. In spite of the aforementioned advantages, the photoanodes obtained from this solvothermal route, however, do not show the satisfactory results in the PEC water splitting measurement. The poor photocurrent densities of 3.5-10 $\mu \mathrm{A} \mathrm{cm}^{-2}$ at $1.23 \mathrm{~V}$ vs. RHE are produced (Table 2) [84, 85]. The 
low PEC performance could be caused by the rich surface defects of $g-\mathrm{C}_{3} \mathrm{~N}_{4}$ particles in film [84].

Direct Growth. In the above-mentioned methods, such as TVC, the solid precursor is not in direct contact with the substrate. In the reaction, the solid precursors are firstly gasified, diffuses to the substrate, and then thermally polymerizes to form the $\mathrm{g}-\mathrm{C}_{3} \mathrm{~N}_{4}$ film on the substrate. In contrast, a direct growth process can directly transform the precursors to films without the participation of precursor vapor. In the direct growth method, the solid precursors are contacted with the substrates and directly transformed into the $\mathrm{g}-\mathrm{C}_{3} \mathrm{~N}_{4}$ film on substrates by thermal polymerization (Figure 3e) [86].

In this method, the $\mathrm{g}-\mathrm{C}_{3} \mathrm{~N}_{4}$ films can be grown onto different substrates, ranging from frequently-used FTO, glass slides, to metal oxide films ( $\mathrm{TiO}_{2}$ and $\mathrm{ZnO}$ ). Importantly, the morphology of $\mathrm{g}-\mathrm{C}_{3} \mathrm{~N}_{4}$ films can be adjusted to various structures, including nanorod arrays (Figure 4m) [86], porous films (Figure 4n) [86], or dense films (Figure 4o and p) [87], So the direct growth route provides not only an easy and feasible strategy for the fabrication of $\mathrm{g}-\mathrm{C}_{3} \mathrm{~N}_{4}$ films, but also a promising way for the preparation of $\mathrm{g}-\mathrm{C}_{3} \mathrm{~N}_{4}$-based heterofilms. In the PEC water splitting performance test, the photoanode based on the film prepared by direct growth show a photocurrent density of $22 \mu \mathrm{A} \mathrm{cm}^{-2}$ at $0.5 \mathrm{~V} v$ s. RHE.

Obviously, the bottom-up route can provide the convenient, versatile, and efficient fabrication strategies of $\mathrm{g}-\mathrm{C}_{3} \mathrm{~N}_{4}$ films. More importantly, the photoanodes based on the $\mathrm{g}-\mathrm{C}_{3} \mathrm{~N}_{4}$ films obtained from the bottom-up technology show greater superiority than that of the top-down approach, in terms of 1) the better uniformity of the films grown on substrates [82]; 2) the more intimate contact between films and substrates [84]; and 3) the more facile morphology control for enhancing the PEC water splitting performance $[79,84,86]$. Hence, the photoanodes from bottom-up technology display an enhanced PEC water splitting performance. 


\subsection{Enhancement Strategies for PEC Water Splitting Performance of g- $\mathrm{C}_{3} \mathrm{~N}_{4}$ Films}

As above-mentioned, except for the difficulty in $\mathrm{g}-\mathrm{C}_{3} \mathrm{~N}_{4}$ film preparation ( $i$.e. for achieving high-quality $\mathrm{g}-\mathrm{C}_{3} \mathrm{~N}_{4}$ films, the mature top-down methods are usually unserviceable, and the promising bottom-up approaches are still in their infancy stage), the intrinsic shortcomings of $\mathrm{g}-\mathrm{C}_{3} \mathrm{~N}_{4}$, such as the limited visible-light absorption range, low electrical conductivity, and high recombination rate of photogenerated electrons/holes, are also prevent the material from achieving a high-efficiency PEC water splitting. The breakthrough in these bottlenecks will significantly improve the performance of $\mathrm{g}-\mathrm{C}_{3} \mathrm{~N}_{4}$ films for PEC water splitting. Next, we will introduce some typical and effective ways for enhancing the PEC performance of $\mathrm{g}-\mathrm{C}_{3} \mathrm{~N}_{4}$ films, including introduction of functional groups [80, 88], and heteroelement doping [89-91].

Introduction of Functional Groups. Modification of $\mathrm{g}-\mathrm{C}_{3} \mathrm{~N}_{4}$ films by functional groups, the typical molecular modification of materials, has been regarded as a promising route to enhance its PEC water splitting performance. Recently, the $\mathrm{sp}^{2} \mathrm{C}$ has been introduced into $\mathrm{g}-\mathrm{C}_{3} \mathrm{~N}_{4}$ films through the copolymerization of 2, 6-diaminopyridine (26D) and melamine, to mediate the electronic structure of $\mathrm{g}-\mathrm{C}_{3} \mathrm{~N}_{4}$ for more excellent optic and electrical properties [80]. In this process, 26D as the source of $\mathrm{sp}^{2} \mathrm{C}$ was added into the precursor of $\mathrm{g}-\mathrm{C}_{3} \mathrm{~N}_{4}$ films. The successful integration of $\mathrm{sp}^{2}$ $\mathrm{C}$ into $\mathrm{g}-\mathrm{C}_{3} \mathrm{~N}_{4}$ films lead to the increased $\mathrm{C} / \mathrm{N}$ ratio in modified $\mathrm{g}-\mathrm{C}_{3} \mathrm{~N}_{4}$ films with the increment of weight ratio of $26 \mathrm{D}$ in co-monomer (Figure 5a). Importantly, it was found that the $\mathrm{sp}^{2} \mathrm{C}$ can enhance the optical properties of $\mathrm{g}-\mathrm{C}_{3} \mathrm{~N}_{4}$ films as well as reduce the resistance of charge separation and transport (Figure 5b, c). As a result, the highest photocurrent density of $0.1 \mathrm{~mA} \mathrm{~cm}^{-2}$ at $1.23 \mathrm{~V}$ vs. RHE was achieved by the $\mathrm{g}-\mathrm{C}_{3} \mathrm{~N}_{4}$ film with $5 \%$ weight ratio of $26 \mathrm{D}$ (Figure 5d). 


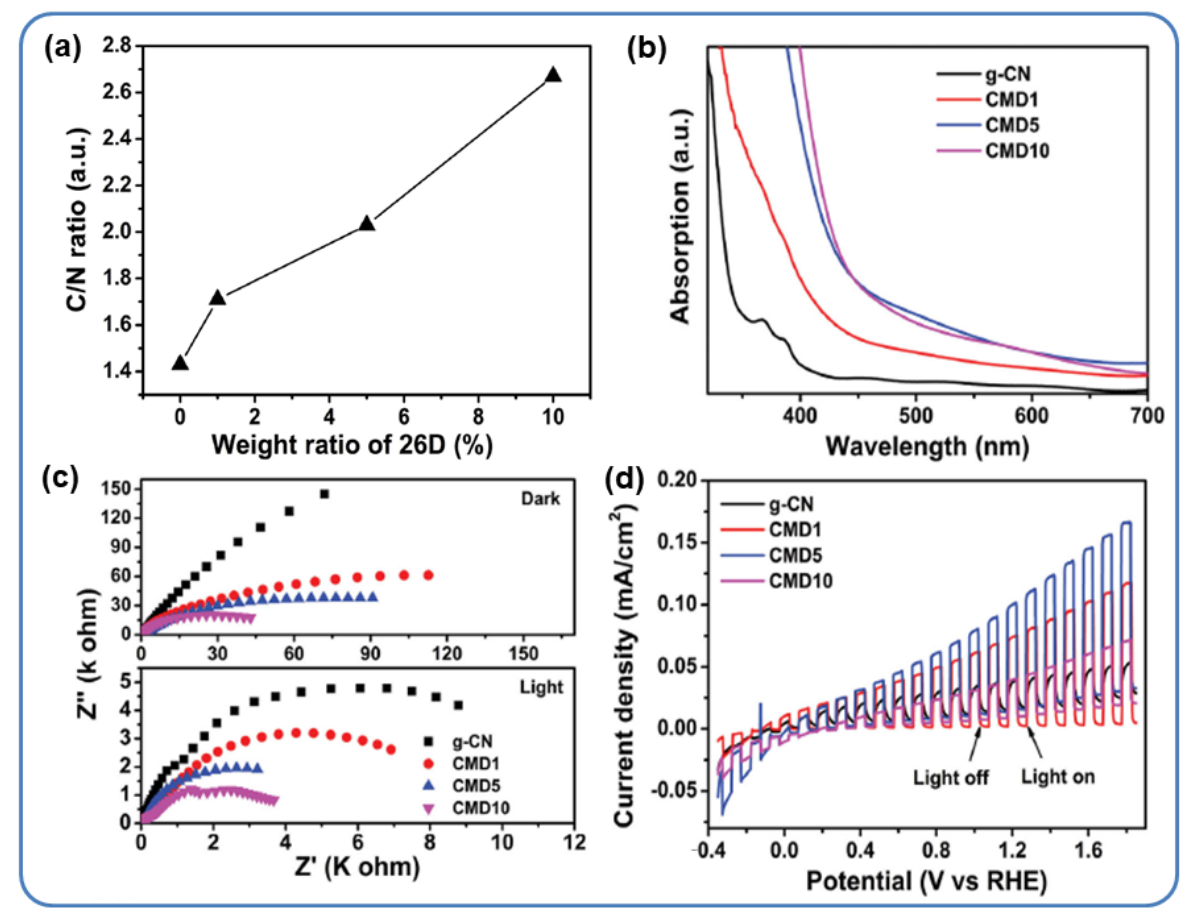

Figure 5 (1.5-column). (a) $\mathrm{C} / \mathrm{N}$ atom ratio, (b) UV-vis absorption spectra, (c) EIS plots at $1.23 \mathrm{~V}$ vs. RHE in the dark and light, and (d) light-chopped linear sweep voltammetry (LSV) curves of the pristine and 26D modified g- $\mathrm{C}_{3} \mathrm{~N}_{4}$ films with different weight ratios. CMD1, CMD5, and CMD10 refer to the modified $\mathrm{g}-\mathrm{C}_{3} \mathrm{~N}_{4}$ films with 1 , 5 , and $10 \%$ weight ratio of 26D, respectively. Reprinted from refs. [80] with permission.

Moreover, the $\mathrm{sp}^{2} \mathrm{C}$ has also been added introduced into $\mathrm{g}-\mathrm{C}_{3} \mathrm{~N}_{4}$ films to improve the optical and electrical properties by the phenyl-modified approach [88]. Interestingly, the molten sulfur, which was used as a solvent at high temperature, can bring a more effective integration of $\mathrm{sp}^{2} \mathrm{C}$ into the $\mathrm{g}-\mathrm{C}_{3} \mathrm{~N}_{4}$ framework, resulting in an extended light absorption, a facile exciton separation, and an improved conductivity. Consequently, $\mathrm{g}-\mathrm{C}_{3} \mathrm{~N}_{4}$ film photoanode obtained from the precursor with $600 \mathrm{mg}$ sulfur behaves the highest photocurrent density of about $60 \mu \mathrm{A} \mathrm{cm}{ }^{-2}$, which is 20.7 times than that of the $\mathrm{g}-\mathrm{C}_{3} \mathrm{~N}_{4}$ film photoanodes without sulfur in its precursor $\left(2.9 \mu \mathrm{A} \mathrm{cm}^{-2}\right)$.

Heteroatoms Doping. Doping of additional atoms into the $\mathrm{g}-\mathrm{C}_{3} \mathrm{~N}_{4}$ matrix has been considered as an effective strategy to regulate its physicochemical properties, including extending visible light absorption scope, suppressing the recombination of photogenerated electrons/holes, etc. Up to now, 
both metallic (e.g. K, Co, Fe) [92-95] and nonmetallic elements (e.g. N, O, P, B) [96-99] have been introduced into $\mathrm{g}-\mathrm{C}_{3} \mathrm{~N}_{4}$ as dopants, but most of products are still agglomerates, powders, and nanosheets. Recently, the elemental doping technology has been successfully combined with the bottom-up approach to fabricate the doped $\mathrm{g}-\mathrm{C}_{3} \mathrm{~N}_{4}$ films with an enhanced PEC water splitting performance.
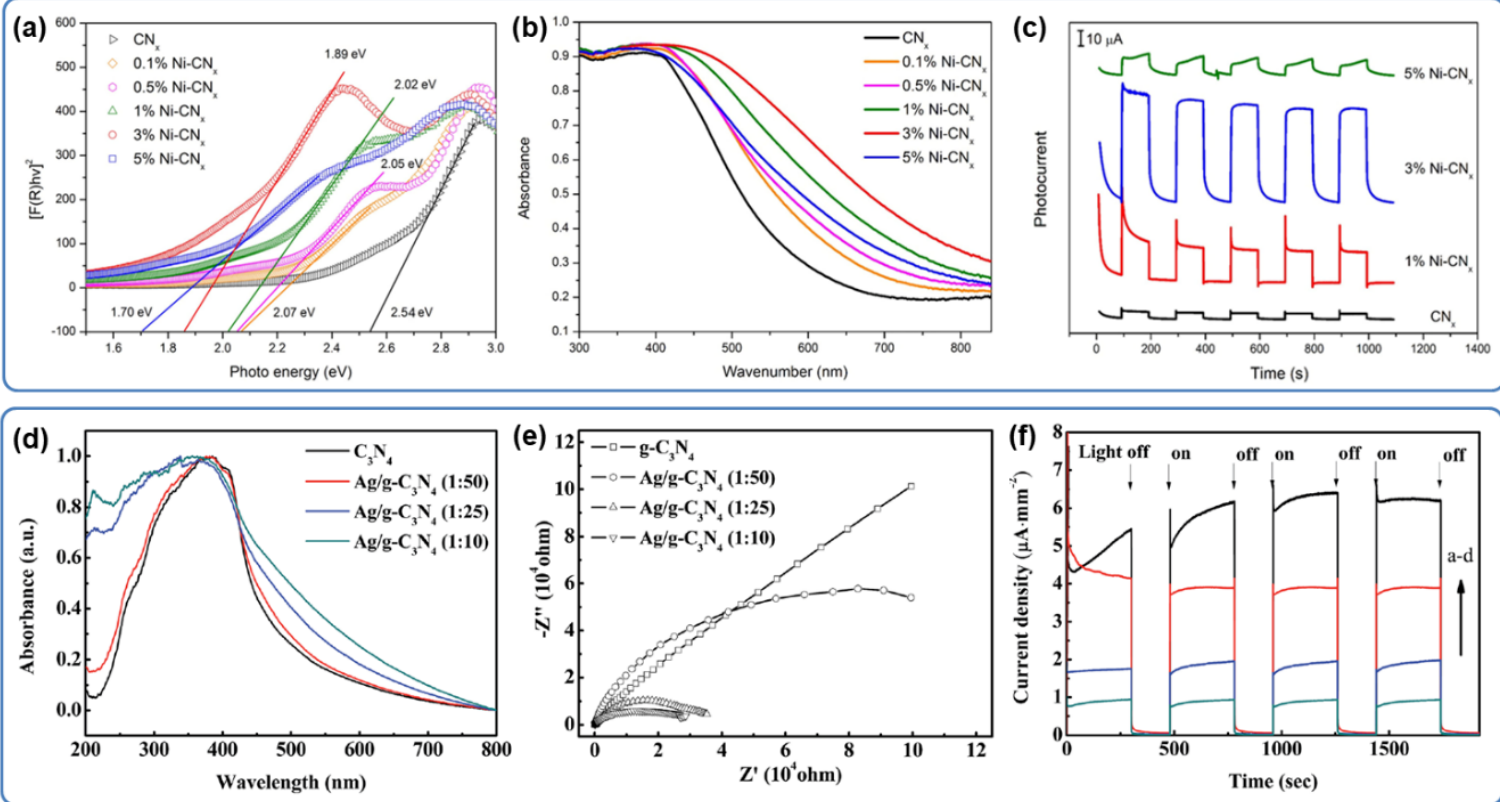

Figure 6 (2-column). (a) Kubelka-Munk function vs. energy plots, (b) UV-vis absorbance spectrum, (c) transient

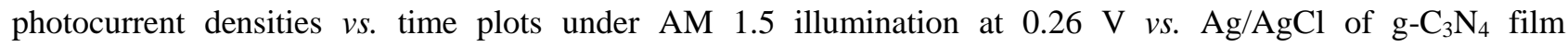
photoelectrodes with different Ni doping amount. Reprinted from refs. [89] with permission. (d) UV-vis absorbance spectrum, (e) Nyquist plots, and (f) transient photocurrent densities vs. time plots under visible light $(\lambda>420 \mathrm{~nm})$ at $1.0 \mathrm{~V}$ vs. SCE for $\mathrm{g}-\mathrm{C}_{3} \mathrm{~N}_{4}$ film photoelectrodes with different $\mathrm{Ag}$ doping amount. Reprinted from refs. [90] with permission.

$\mathrm{Ni}$, as a frequently-used metallic dopant, has been homogeneously dispersed throughout $\mathrm{g}-\mathrm{C}_{3} \mathrm{~N}_{4}$ film in the direct growth process [89]. Importantly, the doped Ni ions could affect the electronic structure of $\mathrm{g}-\mathrm{C}_{3} \mathrm{~N}_{4}$, resulting in a conspicuous decrease in band gap from 2.54 to $1.70 \mathrm{eV}$ with the increased Ni doping amount from 0 to 5 wt.\% (Figure 6a), corresponding to a remarkable red-shift 
in its absorption spectra (Figure 6b). Besides, the doped $\mathrm{Ni}$ ions can also facilitate the OER by means of promoting the formation of hydroperoxide $(-\mathrm{OOH})$ species (key intermediates in the OER). The optimal PEC performance was owned by the 3 wt.\% $\mathrm{Ni}$ doped $\mathrm{g}_{-} \mathrm{C}_{3} \mathrm{~N}_{4}$ film. The photocurrent density achieved $69.8 \mu \mathrm{A} \mathrm{cm}^{-2}$ at $0.26 \mathrm{~V} v s . \mathrm{Ag} / \mathrm{AgCl}$ (Figure 6c).

Apart from $\mathrm{Ni}, \mathrm{Ag}$ has also been introduced into the $\mathrm{g}-\mathrm{C}_{3} \mathrm{~N}_{4}$ film. Similar to $\mathrm{Ni}$, the $\mathrm{Ag}$ species in the matrix of the $\mathrm{g}-\mathrm{C}_{3} \mathrm{~N}_{4}$ film can also enhance the visible light harvesting (Figure 6d). Besides, the Ag-doped $\mathrm{g}-\mathrm{C}_{3} \mathrm{~N}_{4}$ films show the stronger ability of exciton separation and charge transfer compared with pristine $\mathrm{g}-\mathrm{C}_{3} \mathrm{~N}_{4}$ film (Figure 6e). In consequence, the Ag-doped $\mathrm{g}-\mathrm{C}_{3} \mathrm{~N}_{4}$ film photoanodes show higher photocurrent densities than the pristine $\mathrm{g}-\mathrm{C}_{3} \mathrm{~N}_{4}$ photoanode (Figure 6f) [90].

(a)

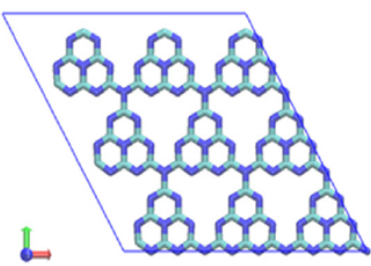

(b)

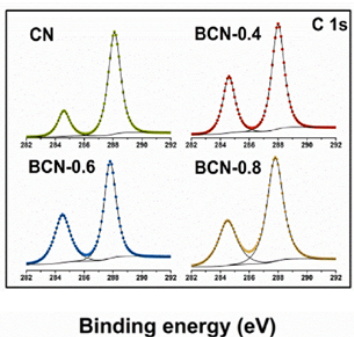

(e)

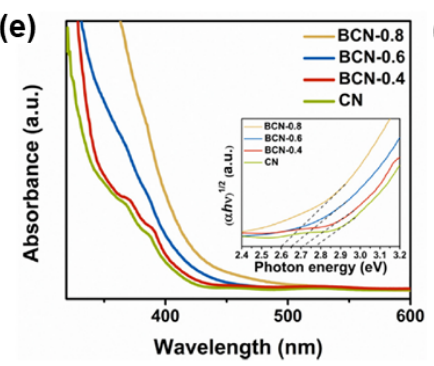

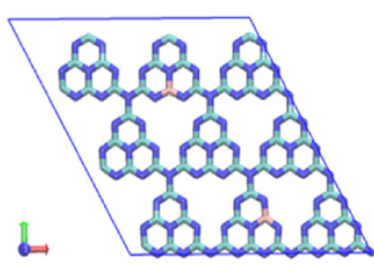

(c) $\mathrm{CN}$

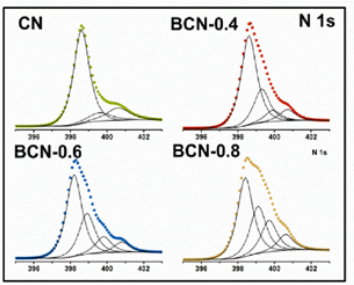

Binding energy (eV)

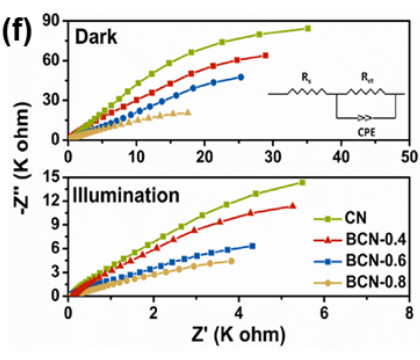

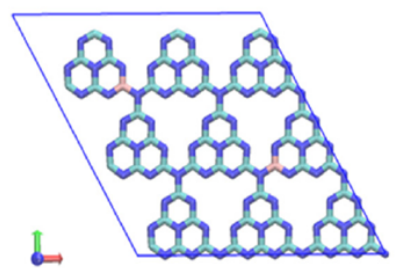
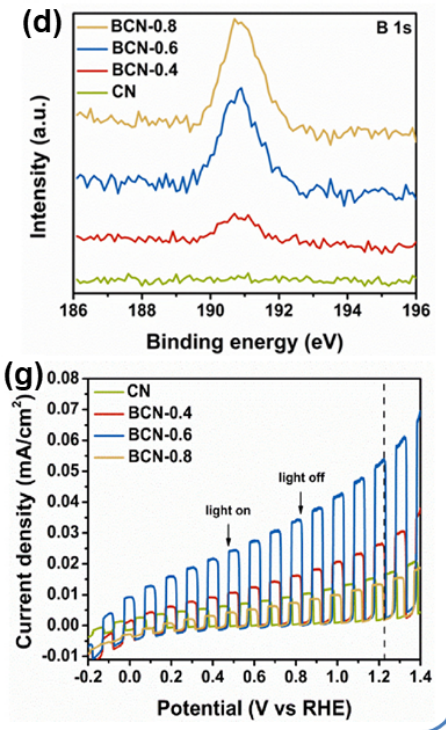

Figure 7 (2-column). (a) Top views of super-cell $3 \times 3$ pristine $\mathrm{g}-\mathrm{C}_{3} \mathrm{~N}_{4}$ (left) and $\mathrm{BCN}-0.6$ with two $\mathrm{C}$ substituted by $\mathrm{B}$ at corner (middle) and bay (right) sites in a lattice with constants of $a=b=21.04 \AA, c=20.0 \AA$, and $\alpha=\beta=90^{\circ}$, 
$\gamma=120^{\circ}$ by DFT optimizations. The green, blue, and pink colors represent C, N, and B atoms, respectively. The XPS spectra of (b) C 1s, (c) N 1s and (d) B 1s for B doping g- $\mathrm{C}_{3} \mathrm{~N}_{4}$ films. (e) UV-vis absorption spectrum, (f) Nyquist plots, and (g) light chopped LSV curves under AM 1.5 illumination of B doping g- $\mathrm{C}_{3} \mathrm{~N}_{4}$ film photoanodes. The inset in e is the Kubelka-Munk function $v s$. energy plots. Reprinted from refs. [91] with permission.

Nonmetallic elements (e.g. B) can also be incorporated into the $\mathrm{g}-\mathrm{C}_{3} \mathrm{~N}_{4}$ films to improve PEC ability through a typical TVC process using a mixture of melamine and boric acid as the precursor. [91]. The $\mathrm{B}$ atoms embedded into $\mathrm{g}-\mathrm{C}_{3} \mathrm{~N}_{4}$ matrix substitute the $\mathrm{C}$ atoms in the bay sites, resulting in the formation of C-B bonds (Figure 7a-d). This compositional change brings a significant influence on the electronic structure of the $\mathrm{g}-\mathrm{C}_{3} \mathrm{~N}_{4}$ films. As a result, the band gap of B-doped $\mathrm{g}-\mathrm{C}_{3} \mathrm{~N}_{4}$ films decreased from 2.77 to $2.60 \mathrm{eV}$ with the increase of boric acid added amount in precursor from 0 to $0.8 \mathrm{~g}$, corresponding to a remarkable enhancement on visible light absorption spectra (Figure 7e). Meanwhile, the recombination of photogenerated electrons and holes is suppressed, and charge transfer process is accelerated (Figure 7f). Consequently, the photoanode with boric acid added amount of $0.6 \mathrm{~g}$ in precursor produced the highest photocurrent density of $55 \mu \mathrm{A} \mathrm{cm} \mathrm{cm}^{-2}$ at $1.23 \mathrm{~V}$ vs.

\section{RHE (Figure 6g).}

In a word, the introduction of functional groups or heteroelements into $\mathrm{g}-\mathrm{C}_{3} \mathrm{~N}_{4}$ films based on the novel bottom-up route can not only obtain high-quality g- $\mathrm{C}_{3} \mathrm{~N}_{4}$ films, but also enhance the PEC water splitting performance.

\section{4. g- $\mathrm{C}_{3} \mathrm{~N}_{4}$-based Composite Films and Their PEC Water Splitting Performance}

As aforementioned, the pristine $\mathrm{g}_{-} \mathrm{C}_{3} \mathrm{~N}_{4}$ films usually do not possess satisfactory PEC performance, due to their intrinsic drawbacks, such as insufficient visible-light absorption, low electrical conductivity, and high recombination rate of photogenerated electrons and holes. 
Although introducing functional groups or heteroatoms into $\mathrm{g}-\mathrm{C}_{3} \mathrm{~N}_{4}$ films can improve the PEC performance, the destruction of $\mathrm{g}-\mathrm{C}_{3} \mathrm{~N}_{4}$ structure and formation of defect could bring a number of negative effects, such as photogenerated electrons being captured and then recombined at the defects in $\mathrm{g}-\mathrm{C}_{3} \mathrm{~N}_{4}$ films.

Recently, compositing $\mathrm{g}-\mathrm{C}_{3} \mathrm{~N}_{4}$ with a secondary semiconductor to form a composite film has been intensively studied, due to its abilities of suppressing the recombination and enhancing the visible-light absorption, resulting in the enhancement on PEC water splitting performance. Importantly, the introduced secondary semiconductor materials normally do not affect the molecular structure and the properties of $g-\mathrm{C}_{3} \mathrm{~N}_{4}$, therefore, the advantages of $\mathrm{g}-\mathrm{C}_{3} \mathrm{~N}_{4}$ can be successfully kept. Up to now, a series of semiconducting materials have been coupled with $\mathrm{g}-\mathrm{C}_{3} \mathrm{~N}_{4}$, including the wide band-gap metal oxides, metal sulfides, $p$-type semiconductor, and so on. In this section, this new strategy of constructing g- $\mathrm{C}_{3} \mathrm{~N}_{4}$-based composite films will be discussed.

\subsection{Principles of $\mathrm{g}-\mathrm{C}_{3} \mathrm{~N}_{4}$-based Heterojunctions}

In a $\mathrm{g}-\mathrm{C}_{3} \mathrm{~N}_{4}$-based composite film, g- $\mathrm{C}_{3} \mathrm{~N}_{4}$ and a secondary semiconducting material are coupled to form heterojunctions, which play a key role in improving the PEC water splitting performance. According to the separation mechanism of photogenerated electron and holes, the $\mathrm{g}_{-} \mathrm{C}_{3} \mathrm{~N}_{4}$-based composites can be categorized into four classifications: type I, type II, type III, and Z-scheme heterojunction $[3,100]$. 


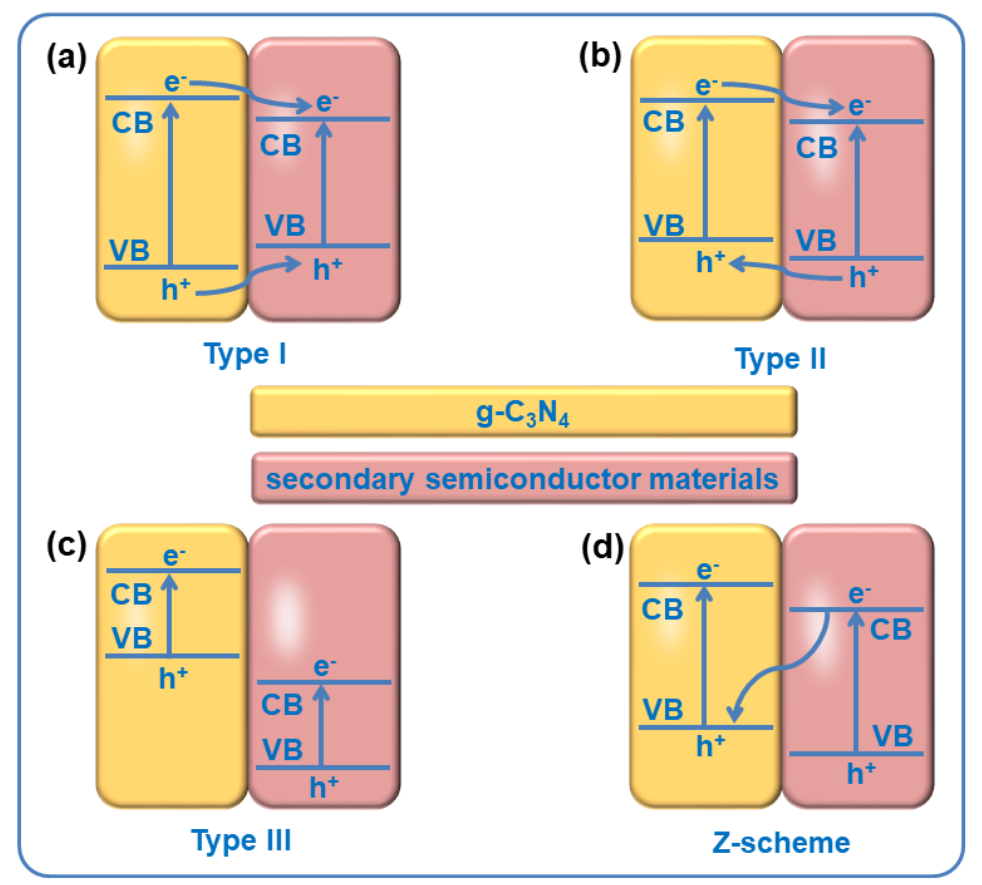

Figure 8 (1.5-column). Schematic energy band diagram of (a) type I, (b) type II, (c) type III, and (d) Z-scheme heterojunction constructed by $\mathrm{g}-\mathrm{C}_{3} \mathrm{~N}_{4}$ and a secondary semiconductor material.

In a type I heterojunction, both VB and CB of the secondary semiconductor are within band gap region of $\mathrm{g}_{-} \mathrm{C}_{3} \mathrm{~N}_{4}$, thereby building a straddling band alignment (Figure 8a). As a result, all the photogenerated electrons and holes are transferred in a single direction towards the secondary semiconductor in this structure, thereby all charges are accumulated in the secondary semiconductor. Obviously, in this case, the photogenerated electrons and holes can hardly be thoroughly separated and the recombination is inevitable [3]. In the type II heterojunction, the band edge potentials of g- $\mathrm{C}_{3} \mathrm{~N}_{4}$ and the secondary semiconductor are staggered (Figure 8b). Consequently, the photogenerated electrons are transferred from the $\mathrm{CB}$ of $\mathrm{g}_{-} \mathrm{C}_{3} \mathrm{~N}_{4}$ to the $\mathrm{CB}$ of the secondary semiconductor, while the holes migrate towards the opposite direction. This double-charge transfer mechanism significantly improves the separation rate of excitons, leading to the inhibited recombination of the photogenerated electrons/holes [101, 102]. In the type III heterojunction, the VB and $\mathrm{CB}$ of $\mathrm{g}-\mathrm{C}_{3} \mathrm{~N}_{4}$ and the secondary semiconductor do not overlap with each other (Figure 8c), 
which does not affect the separation of photogenerated electrons and holes. At last, a new type of heterostructure, named Z-scheme heterojunction, has been reported in recently [103-105]. In the Z-scheme heterojunction, the photogenerated electrons in the $\mathrm{CB}$ of the secondary semiconductor are directly transferred to the $\mathrm{VB}$ of $\mathrm{g}-\mathrm{C}_{3} \mathrm{~N}_{4}$, thus leading to the efficient separation of the photogenerated electrons in the $\mathrm{CB}$ of $\mathrm{g}_{-} \mathrm{C}_{3} \mathrm{~N}_{4}$ and the holes in the secondary semiconductor (Figure 8d). Based on the above discussions, only the type II and Z-scheme $\mathrm{g}_{-} \mathrm{C}_{3} \mathrm{~N}_{4}$-based heterojunctions are effective in separating the photogenerated electrons and holes, thus desirable in the construction of a $\mathrm{g}-\mathrm{C}_{3} \mathrm{~N}_{4}$-based film.

Other than the improved separation and suppressed recombination, compositing $g-\mathrm{C}_{3} \mathrm{~N}_{4}$ with the secondary semiconductors can also modify the material's visible-light adsorption behavior, bringing a more effective utilization for solar energy. In the following sections, we will summarize the progress of $\mathrm{g}-\mathrm{C}_{3} \mathrm{~N}_{4}$-based composite films for PEC water splitting.

\section{2. g- $\mathrm{C}_{3} \mathrm{~N}_{4}$-based Type II Heterojunction Composite Films}

As above-mentioned, the type II heterojunction, constituted by $\mathrm{g}-\mathrm{C}_{3} \mathrm{~N}_{4}$ and a secondary semiconductor, not only enhances the visible light absorption but also suppresses the recombination of photogenerated electrons/holes. Therefore, a series of semiconducting materials, including wide band-gap metal oxides (e.g. $\left.\mathrm{TiO}_{2}, \mathrm{SnO}_{2}\right)$, metal sulfides (e.g. $\left.\mathrm{CdS}\right)$, and ternary oxides (e.g. $\left.\mathrm{BiVO}_{4}\right)$, have been introduced into the $\mathrm{g}-\mathrm{C}_{3} \mathrm{~N}_{4}$ films to forming the $\mathrm{g}-\mathrm{C}_{3} \mathrm{~N}_{4}$-based type II heterojunction to achieve an improved PEC water splitting performance.

Firstly, wide band-gap metal oxides, such as $\mathrm{TiO}_{2}$ and $\mathrm{SnO}_{2}$, are the most extensively studied photoanode materials for PEC water splitting, due to their good physicochemical stability, low cost, and facile fabrication [106-109]. Nevertheless, their extremely wide band gap of $\sim 3.2-3.4 \mathrm{eV}$ usually results in a poor visible-light absorption ability, which hinders the further enhancement of 
their PEC performance. However, the band edge positions of $\mathrm{TiO}_{2}$ and $\mathrm{SnO}_{2}$ are considered quite suitable to be coupled with $\mathrm{g}-\mathrm{C}_{3} \mathrm{~N}_{4}$ to form composite films with type II heterojunctions [71, 110, 111], leading to a much enhanced PEC water splitting performance compared with the pristine $\mathrm{TiO}_{2}$, $\mathrm{SnO}_{2}$, and $\mathrm{g}-\mathrm{C}_{3} \mathrm{~N}_{4}$ films.

Generally, the $\mathrm{TiO}_{2} / \mathrm{g}-\mathrm{C}_{3} \mathrm{~N}_{4}$ and $\mathrm{SnO}_{2} / \mathrm{g}-\mathrm{C}_{3} \mathrm{~N}_{4}$ composite films can be fabricated by the top-down approach using the pre-prepared composite powders as the starting materials (Figure 9a and e). Importantly, the composite films show more excellent optic and electrical properties than the pristine $\mathrm{TiO}_{2}, \mathrm{SnO}_{2}$, and $\mathrm{g}-\mathrm{C}_{3} \mathrm{~N}_{4}$ films, including the strong absorption in the visible range (Figure 9b and $\mathbf{f}$ ), and the accelerated separation and transfer of photogenerated charge (Figure 9c and $\mathbf{g}$ ). As a result, the $\mathrm{TiO}_{2} / \mathrm{g}-\mathrm{C}_{3} \mathrm{~N}_{4}$ and $\mathrm{SnO}_{2} / \mathrm{g}-\mathrm{C}_{3} \mathrm{~N}_{4}$ film photoanodes show higher photocurrent densities than the pristine $\mathrm{TiO}_{2}, \mathrm{SnO}_{2}$, and $\mathrm{g}-\mathrm{C}_{3} \mathrm{~N}_{4}$ photoanodes, respectively (Figure 10d and $\mathbf{h}$ ) [71, 111]
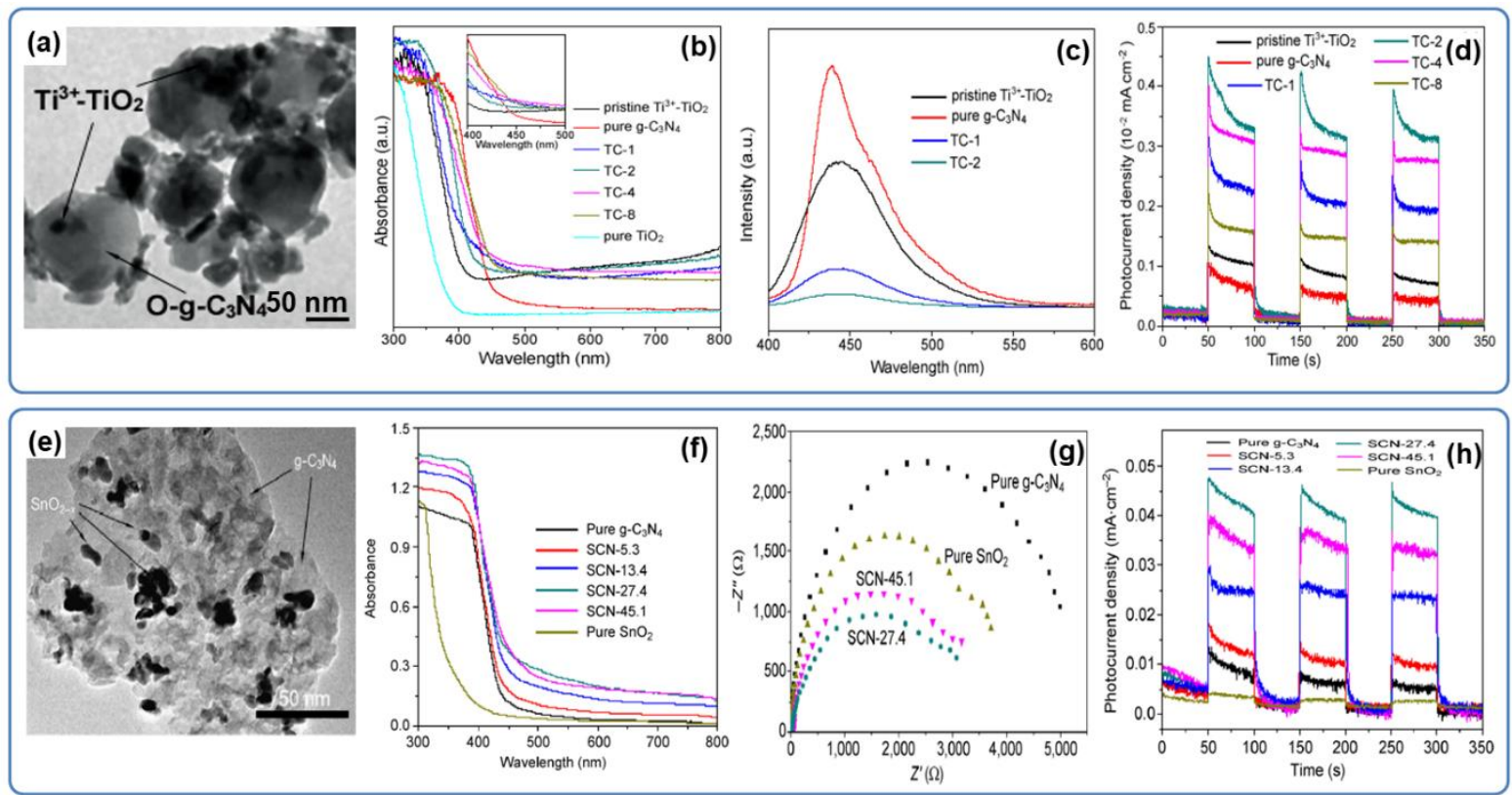

Figure 9 (2-column). (a) TEM image of TC-8 sample. (b) UV-vis absorption spectra of $\mathrm{TiO}_{2}, \mathrm{~g}-\mathrm{C}_{3} \mathrm{~N}_{4}$, and $\mathrm{TiO}_{2} / \mathrm{g}-\mathrm{C}_{3} \mathrm{~N}_{4}$ heterojunctions. (c) Photoluminescence (PL) spectra of $\mathrm{TiO}_{2}, \mathrm{~g}-\mathrm{C}_{3} \mathrm{~N}_{4}$, and TC-1 and TC-2 heterojunctions. (d) Transient photocurrent densities vs. time plots of $\mathrm{TiO}_{2} / \mathrm{g}-\mathrm{C}_{3} \mathrm{~N}_{4}$ composite film photoanodes. Reprinted from refs. [110] with permission. (e) TEM image of SCN-45.1 sample. (f) UV-vis absorption spectra of 
$\mathrm{SnO}_{2}, \mathrm{~g}-\mathrm{C}_{3} \mathrm{~N}_{4}$, and $\mathrm{SnO}_{2} / \mathrm{g}-\mathrm{C}_{3} \mathrm{~N}_{4}$ heterojunctions. (g) Nyquist plots for $\mathrm{g}-\mathrm{C}_{3} \mathrm{~N}_{4}, \mathrm{SnO}_{2}, \mathrm{SCN}-27.4$, and $\mathrm{SCN}-45.1$ samples. (h) Transient photocurrent densities $v s$. time plots of $\mathrm{SnO}_{2} / \mathrm{g}-\mathrm{C}_{3} \mathrm{~N}_{4}$ composite films. Reprinted from Ref. [71] with permission. Here, TC-1, 2, 4, and 8 are the $\mathrm{TiO}_{2} / \mathrm{g}-\mathrm{C}_{3} \mathrm{~N}_{4}$ heterojunction samples with different mass ratios of $\mathrm{TiO}_{2}$ to $\mathrm{g}_{-} \mathrm{C}_{3} \mathrm{~N}_{4}$ at $1: 1,1: 2,1: 4$, and 1:8, respectively. SCN5.3, 13.4, 24.7, and 45.1 refer the represent $\mathrm{SnO}_{2} / \mathrm{g}-\mathrm{C}_{3} \mathrm{~N}_{4}$ heterojunction samples with different percentage content of $\mathrm{SnO}_{2}$ in the composite at 5.3, 13.4, 24.7, and $45.1 \%$, respectively.

Except for the wide band-gap metal oxides, metal sulfides have also been coupled with $\mathrm{g}-\mathrm{C}_{3} \mathrm{~N}_{4}$ to form the type II heterojunctions. Compared with metal oxides, the metal sulfides generally possess a narrower band gap and higher charge mobility, resulting in a stronger visible light absorption and more efficient charge separation [112-114].
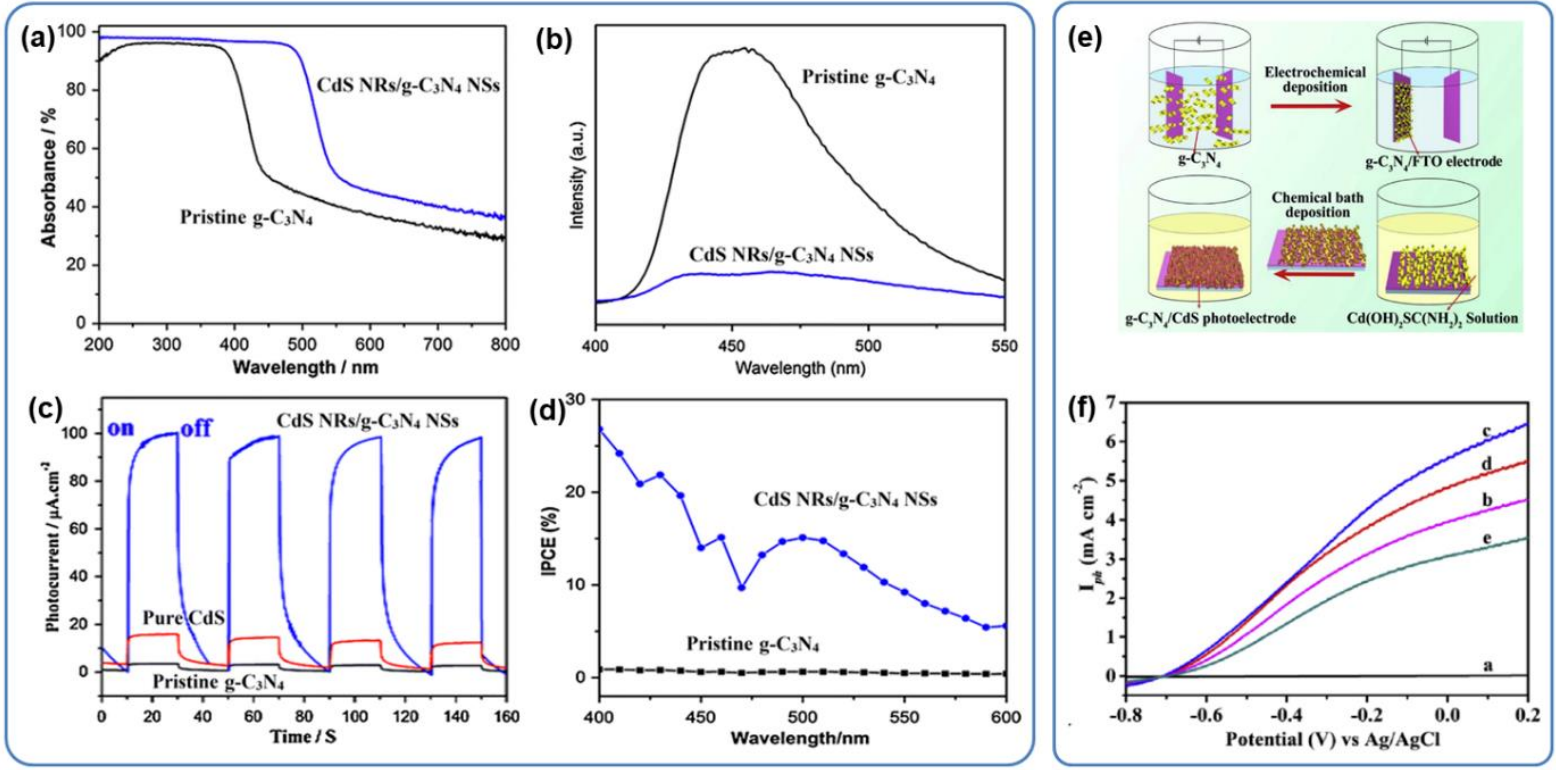

Figure 10 (2-column). (a) UV-vis absorption spectra of g- $\mathrm{C}_{3} \mathrm{~N}_{4}$ and $\mathrm{CdS} / \mathrm{g}-\mathrm{C}_{3} \mathrm{~N}_{4}$ composite films. (b) PL spectra of g- $\mathrm{C}_{3} \mathrm{~N}_{4}$ and $\mathrm{CdS} / \mathrm{g}-\mathrm{C}_{3} \mathrm{~N}_{4}$ composite films. (c) Transient photocurrent densities vs. time plots of $\mathrm{g}-\mathrm{C}_{3} \mathrm{~N}_{4}, \mathrm{CdS}$, and CdS/g- $\mathrm{C}_{3} \mathrm{~N}_{4}$ composite films. (d) IPCE spectra of $\mathrm{g}-\mathrm{C}_{3} \mathrm{~N}_{4}$ and $\mathrm{CdS} / \mathrm{g}-\mathrm{C}_{3} \mathrm{~N}_{4}$ composite films. Reprinted from ref. [115] with permission. (e) Schematic illustration of the formation process of the $\mathrm{CdS} / \mathrm{g}-\mathrm{C}_{3} \mathrm{~N}_{4}$ composite films by a two-step (an electrophoretic deposition and a subsequent in-situ chemical bath deposition). (f) LVS curves of 
g- $\mathrm{C}_{3} \mathrm{~N}_{4}, \mathrm{CdS}$, and $\mathrm{CdS} / \mathrm{g}-\mathrm{C}_{3} \mathrm{~N}_{4}$ composite film photonodes. Herein, a, b, c, d, and e represent the g- $\mathrm{C}_{3} \mathrm{~N}_{4}$, $\mathrm{CdS}-1 \mathrm{~h} / \mathrm{g}-\mathrm{C}_{3} \mathrm{~N}_{4}, \mathrm{CdS}-2 \mathrm{~h} / \mathrm{g}-\mathrm{C}_{3} \mathrm{~N}_{4}, \mathrm{CdS}-3 \mathrm{~h} / \mathrm{g}-\mathrm{C}_{3} \mathrm{~N}_{4}, \mathrm{CdS}$ film photonodes, and $\mathrm{h}$ refer to the reaction time in chemical bath deposition. Reprinted from ref. [116] with permission.

To obtain CdS/g- $\mathrm{C}_{3} \mathrm{~N}_{4}$ composite films, a powdery composite of $\mathrm{CdS}$ and $\mathrm{g}-\mathrm{C}_{3} \mathrm{~N}_{4}$ was prepared by a facile hydrothermal route, and then the $\mathrm{CdS} / \mathrm{g}-\mathrm{C}_{3} \mathrm{~N}_{4}$ composite films were fabricated by the conventional top-down approach [115]. This $\mathrm{CdS} / \mathrm{g}-\mathrm{C}_{3} \mathrm{~N}_{4}$ composite film exhibited a stronger optical absorption than the pristine $\mathrm{g}-\mathrm{C}_{3} \mathrm{~N}_{4}$ film in the wavelength range of $430-550 \mathrm{~nm}$ (Figure 10a) and a more efficient separation of photogenerated electrons and holes (Figure 10b). Consequently, this $\mathrm{CdS} / \mathrm{g}-\mathrm{C}_{3} \mathrm{~N}_{4}$ composite film photoanode shows a much higher photocurrent density $(100 \mu \mathrm{A}$ $\left.\mathrm{cm}^{-2}\right)$ than $\mathrm{CdS}\left(17 \mu \mathrm{A} \mathrm{cm}^{-2}\right)$ and $\mathrm{g}_{-} \mathrm{C}_{3} \mathrm{~N}_{4}\left(3.5 \mu \mathrm{A} \mathrm{cm}^{-2}\right)$ film, respectively (Figure 10c). In addition, this $\mathrm{CdS} / \mathrm{g}-\mathrm{C}_{3} \mathrm{~N}_{4}$ composite film photoanode also possesses a higher incident photon-to-current efficiency (IPCE) with the maximum value of $27 \%$ than the pristine $\mathrm{g}-\mathrm{C}_{3} \mathrm{~N}_{4}$ photoanodes (maximum value of $1.2 \%$ ) (Figure 10d).

In other related research, a two-step procedure, including an electrophoretic deposition of g- $\mathrm{C}_{3} \mathrm{~N}_{4}$ onto FTO substrate and a subsequent in-situ chemical bath deposition of $\mathrm{CdS}$ onto g- $\mathrm{C}_{3} \mathrm{~N}_{4}$ /FTO was carried to fabricate the $\mathrm{CdS} / \mathrm{g}-\mathrm{C}_{3} \mathrm{~N}_{4}$ composite films (Figure 10e) [116]. Finally, the $\mathrm{CdS} / \mathrm{g}-\mathrm{C}_{3} \mathrm{~N}_{4}$ composite film photoanode obtained in optimum condition exhibited a maximum photocurrent density of $6.5 \mathrm{~mA} \mathrm{~cm} \mathrm{~cm}^{-2}$ at $0.2 \mathrm{~V} v s . \mathrm{Ag} / \mathrm{AgCl}$ under visible light illumination $(\lambda>420$ nm) (Figure 10f).

Apart from metal oxides and sulfides, $\mathrm{BiVO}_{4}$, a type of ternary oxide, has also been used to composite with g- $\mathrm{C}_{3} \mathrm{~N}_{4}$ due to its good photocatalytic ability under visible light, suitable band edge position for water splitting, and high chemical stability $[117,118]$. The potentials of VB and CB for $\mathrm{BiVO}_{4}$ are 2.80 and $0.27 \mathrm{eV}$, respectively, which is appropriate to form the type II heterojunction 
with $\mathrm{g}-\mathrm{C}_{3} \mathrm{~N}_{4}[119-121]$.

For example, a $\mathrm{BiVO}_{4} / \mathrm{g}-\mathrm{C}_{3} \mathrm{~N}_{4}$ composite film was fabricated by an electrospinning with post-annealing method (Figure 11a and b) [122]. Due to the enhancement of $\mathrm{BiVO}_{4} / \mathrm{g}-\mathrm{C}_{3} \mathrm{~N}_{4}$ heterojunctions on visible light absorption and accelerated separation of excitons, this $\mathrm{BiVO}_{4} / \mathrm{g}-\mathrm{C}_{3} \mathrm{~N}_{4}$ composite film showed an improved PEC water splitting performance. The photocurrent density of $\mathrm{BiVO}_{4} / \mathrm{g}-\mathrm{C}_{3} \mathrm{~N}_{4}$ composite film photoanode reached $0.44 \mathrm{~mA} \mathrm{~cm}{ }^{-2}$ at the bias of $1.23 \mathrm{~V} v s$. RHE, which is much higher than that of pristine $\mathrm{g}_{-} \mathrm{C}_{3} \mathrm{~N}_{4}\left(0.15 \times 10^{-3} \mathrm{~mA} \mathrm{~cm}^{-2}\right)$ and $\mathrm{BiVO}_{4}\left(0.30 \times 10^{-1} \mathrm{~mA} \mathrm{~cm}^{-2}\right)$ film photoanodes, respectively (Figure 11c).
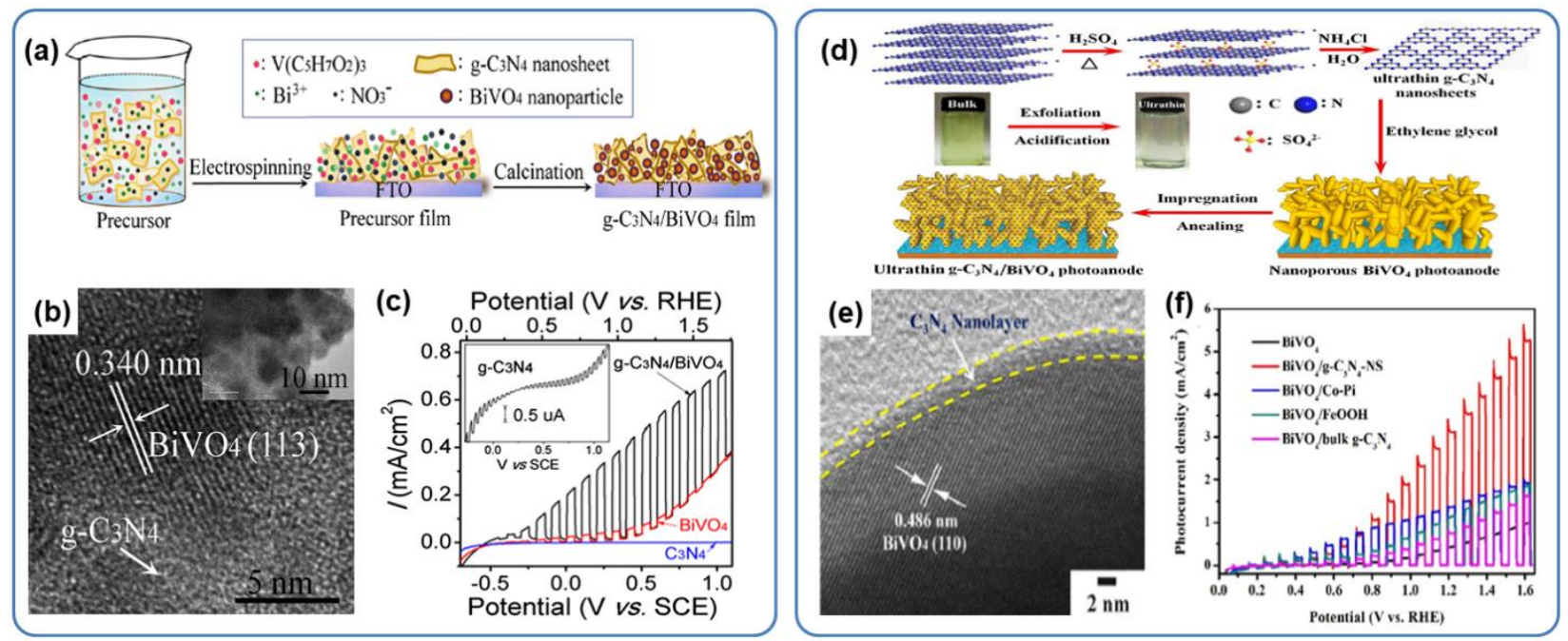

Figure 11 (2-column). (a) Schematic illustration of fabrication process of $\mathrm{BiVO}_{4} / \mathrm{g}-\mathrm{C}_{3} \mathrm{~N}_{4}$ composite film by an electrospinning with post-annealing. (b) HR-TEM image of $\mathrm{BiVO}_{4} / \mathrm{g}-\mathrm{C}_{3} \mathrm{~N}_{4}$ composites. The inset in $\mathrm{b}$ is the HR-TEM image of g- $\mathrm{C}_{3} \mathrm{~N}_{4}$ nanosheets. (c) LSV curves of $\mathrm{BiVO}_{4} / \mathrm{g}-\mathrm{C}_{3} \mathrm{~N}_{4}, \mathrm{BiVO}_{4}$, and $\mathrm{g}-\mathrm{C}_{3} \mathrm{~N}_{4}$ film photoanodes under visible light illumination. The inset in $\mathrm{d}$ is a magnification of LSV curve for the pristine $\mathrm{g}-\mathrm{C}_{3} \mathrm{~N}_{4}$ film photoanode. Reprinted from ref. [122] with permission. (d) Schematic illustration of the exfoliation and acidification process for fabricating composite films of $\mathrm{BiVO}_{4}$ and ultrathin $\mathrm{g}_{-} \mathrm{C}_{3} \mathrm{~N}_{4}$ nanosheets. (e) HR-TEM image of $\mathrm{BiVO}_{4} / \mathrm{g}-\mathrm{C}_{3} \mathrm{~N}_{4}$ core-shell structure heterojunction. (g) LSV curves of $\mathrm{g}-\mathrm{C}_{3} \mathrm{~N}_{4}$ nanosheets @ $\mathrm{BiVO}_{4}$, $\mathrm{BiVO}_{4}, \mathrm{BiVO}_{4} /$ bulk g- $\mathrm{C}_{3} \mathrm{~N}_{4}, \mathrm{BiVO}_{4} / \mathrm{FeOOH}$, and $\mathrm{BiVO}_{4} / \mathrm{CoPi}$ photoanodes under visible light illumination. 
Reprinted from ref. [123] with permission.

The $\mathrm{g}_{-} \mathrm{C}_{3} \mathrm{~N}_{4}$ nanosheets@BiVO $\mathrm{Br}_{4}$ composite material with a rationally designed core-shell structure was also reported, which was fabricated by a simple impregnation method (Figure 11d) [123]. Different from the structure of $\mathrm{BiVO}_{4}$ nanoparticles adhered to $\mathrm{g}-\mathrm{C}_{3} \mathrm{~N}_{4}$ nanosheets reported in ref. 122, the impregnation method provides a novel core-shell structure of $\mathrm{g}_{-} \mathrm{C}_{3} \mathrm{~N}_{4}$ nanosheets@BiVO 4 (Figure 11e). As a result, this composite film showed a high photocurrent density of $3.12 \mathrm{~mA} \mathrm{~cm}^{-2}$ at $1.23 \mathrm{~V}$ vs. RHE under visible light irradiation (Figure 11f). Noticeably, the $\mathrm{BiVO}_{4} / \mathrm{g}-\mathrm{C}_{3} \mathrm{~N}_{4}$ composite films with this heterojunction structure also possessed a higher photocurrent density in comparison with ref. 122 . This could be caused by a more compact contact between $\mathrm{g}-\mathrm{C}_{3} \mathrm{~N}_{4}$ and $\mathrm{BiVO}_{4}$ in core-shell structure, resulting in a faster separation of photogenerated electron/hole pairs.

\section{3. g- $\mathrm{C}_{3} \mathrm{~N}_{4}$-based $\mathrm{Z}$-scheme Heterojunction Composite Films}

Although the $\mathrm{g}-\mathrm{C}_{3} \mathrm{~N}_{4}$-based composite films with type II heterojunctions can increase the separation efficiency and reduce the recombination possibility of the photogenerated electron/hole pairs, a major shortcoming, however, is the poor reduction/oxidation ability of the system [3, 103]. This is mainly caused by the jumping of the photogenerated electrons from the $\mathrm{CB}$ of $\mathrm{g}-\mathrm{C}_{3} \mathrm{~N}_{4}$ to the less negative $\mathrm{CB}$ of the secondary semiconductor; and the transfer of the holes from the VB of the secondary semiconductor to the less positive $\mathrm{VB}$ of $\mathrm{g}-\mathrm{C}_{3} \mathrm{~N}_{4}$, leading to the weakened reduction/oxidation ability (Figure $\mathbf{8 b}$ ). Compared with the type II heterojunctions, the g- $\mathrm{C}_{3} \mathrm{~N}_{4}$-based Z-scheme heterojunctions can not only improve the exciton separation but also maintain the reduction/oxidation ability of the system, because the photogenerated electrons and holes are still kept in the more negative $\mathrm{CB}$ and the more positive $\mathrm{VB}$ in this heterojunction, respectively (Figure 8d) [124-127]. 
In order to fabricate the $\mathrm{g}-\mathrm{C}_{3} \mathrm{~N}_{4}$-based composite films with the $\mathrm{Z}$-scheme heterojunctions, the mixture powders of $\mathrm{NiTiO}_{3}$ and $\mathrm{g}_{-} \mathrm{C}_{3} \mathrm{~N}_{4}$ was calcined at $400{ }^{\circ} \mathrm{C}$ for $2 \mathrm{~h}$ to form the powdery composites of $\mathrm{NiTiO}_{3} / \mathrm{g}-\mathrm{C}_{3} \mathrm{~N}_{4}$ heterojunctions (Figure 12a). Next, the $\mathrm{NiTiO}_{3} / g-\mathrm{C}_{3} \mathrm{~N}_{4}$ composite films were obtained from the slurry of $\mathrm{NiTiO}_{3} / \mathrm{g}-\mathrm{C}_{3} \mathrm{~N}_{4}$ by the spinning-coating process [128]. Importantly, the $\mathrm{NiTiO}_{3} / \mathrm{g}-\mathrm{C}_{3} \mathrm{~N}_{4}$ composite films exhibit an ability of photocatalytic degradation for rhodamine B (Figure 12b and $\mathbf{c}$ ), indicating that the mechanism of exciton separation and transfer in this films is the Z-scheme (Figure 12d).
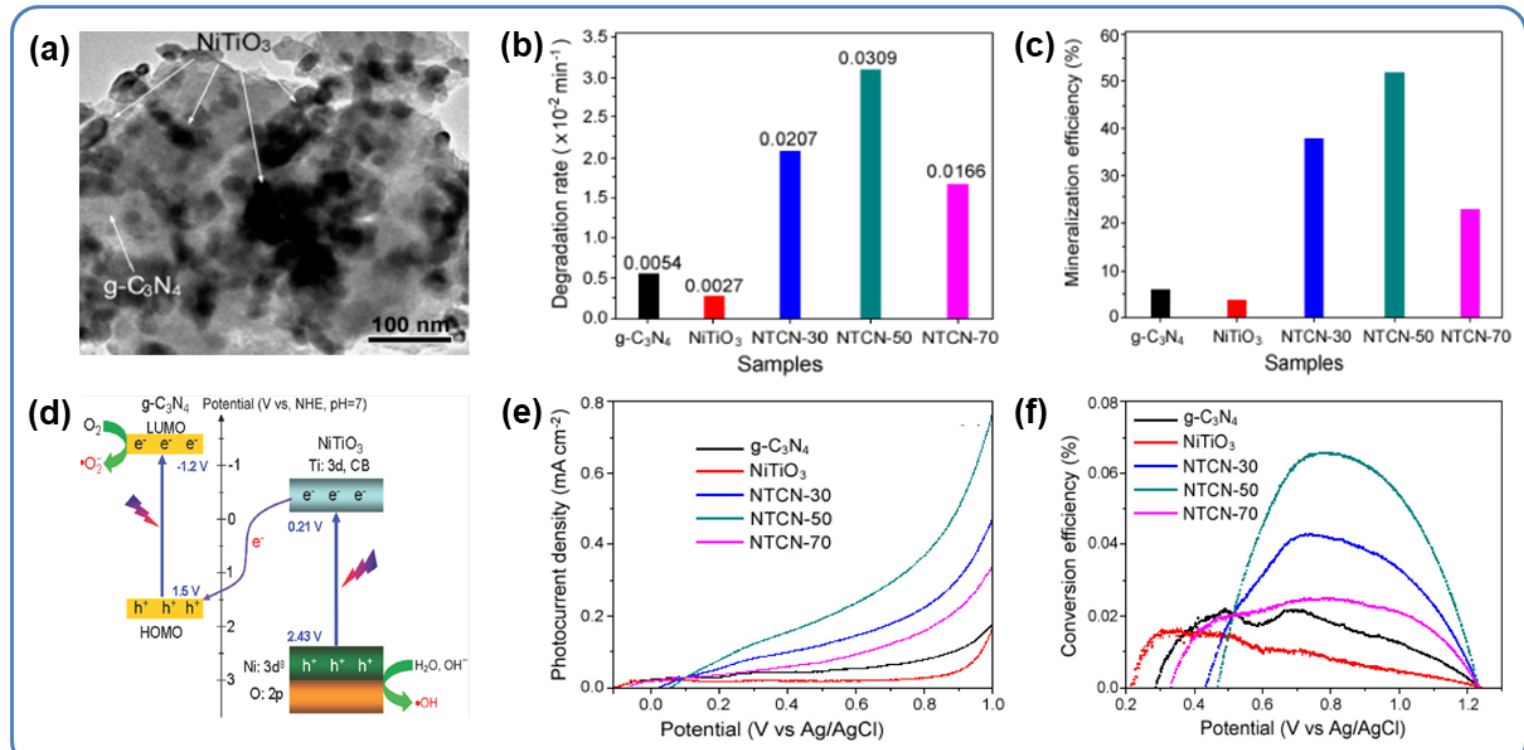

Figure 12 (2-column). (a) TEM image of NTCN-50. (b) Photodegradation rate and (c) mineralization efficiency of rhodamine B by using pure $\mathrm{g}-\mathrm{C}_{3} \mathrm{~N}_{4}, \mathrm{NiTiO}_{3}$ and $\mathrm{NTCN}-30, \mathrm{NTCN}-50$ and NTCN-70 as photocatalyst. (d) Schematic diagram of mechanism of the $\mathrm{NiTiO}_{3} / \mathrm{g}-\mathrm{C}_{3} \mathrm{~N}_{4}$ Z-scheme heterojunction under visible-light LED irradiation. (e) $\mathrm{LSV}$ and (f) calculated photoconversion efficiencies results for the pure $\mathrm{g}-\mathrm{C}_{3} \mathrm{~N}_{4}, \mathrm{NiTiO}_{3}$ and NTCN-30, NTCN-50 and NTCN-70 film photoanodes. Here, NTCN-30, NTCN-50, and NTCN-70 refer to the $\mathrm{NiTiO}_{3} / \mathrm{g}-\mathrm{C}_{3} \mathrm{~N}_{4}$ with various $\mathrm{NiTiO}_{3}$ mass ratios of 30,50 , and 70 w.t. $\%$, respectively. Reprinted from ref. [128] with permission.

Due to the accumulated separation of photogenerated electrons and holes by $\mathrm{NiTiO}_{3} / \mathrm{g}-\mathrm{C}_{3} \mathrm{~N}_{4}$ 
Z-scheme heterojunctions, $\mathrm{NiTiO}_{3} / \mathrm{g}-\mathrm{C}_{3} \mathrm{~N}_{4}$ composite films showed an enhanced PEC water splitting performance. Especially, the composite films with 50 wt.\% $\mathrm{NiTiO}_{3}$ owned the best PEC property, and its photocurrent density and photoconversion efficiency were $400 \mathrm{~mA} \mathrm{~cm}{ }^{-2}$ and $0.066 \%$ at about $0.8 \mathrm{~V} v$ s. $\mathrm{Ag} / \mathrm{AgCl}$, respectively (Figure 12e and $\mathbf{f}$ ).

\section{4. g- $\mathrm{C}_{3} \mathrm{~N}_{4}$-based Composite Films for Photocathodes}

The above mentioned PEC water splitting processes are based on the photoanodes with $n$-type semiconductors as the working electrode. Besides, the PEC water splitting cells can also utilize the p-type semiconductor as the photocathode to carry out the water splitting reaction under solar light radiation [129-131]. In a water splitting process based on the photocathode, when the incident light irradiates the photocathode, electrons in the VB are excited, and then transfers to the $\mathrm{CB}$, leaving the holes in VB (step 1 in Figure 13). Next, the photogenerated electrons in CB are migrated from interior to surface of photocathode (step 2 in Figure 13), and then reduce the dissociated protons in electrolyte and generate hydrogen gas (HER) (step 3 in Figure 13). The holes in VB are transported to the anode through the outer circuit (step 4 in Figure 13), and then oxidize the water to produce oxygen gas (OER) (step 5 in Figure 13). Apart from the ones that drive the water splitting reaction, the rest of the photogenerated electrons and holes, which fail to reach the photoelectrode surface in their migration process, will be recombined and neutralized (step 6 in Figure 13). 


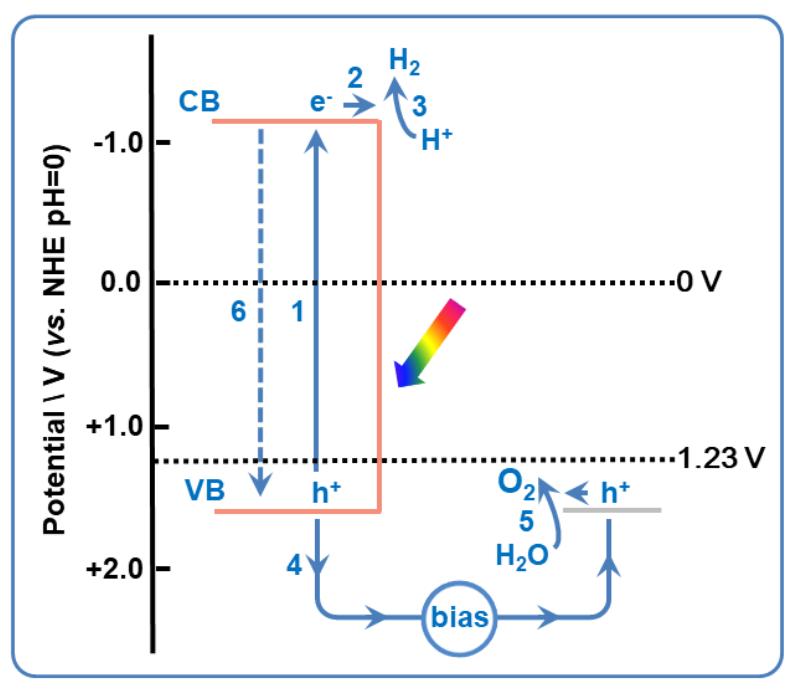

Figure 13 (1-column). Schematic illustration of basic procedure and main reaction for photocathode-based PEC water splitting process.

Similar to the composite films of $\mathrm{g}-\mathrm{C}_{3} \mathrm{~N}_{4}$ and $n$-type semiconductors for photoanodes, the g- $\mathrm{C}_{3} \mathrm{~N}_{4} / p$-type semiconductor composite films for photocathode can also suppress the recombination of photogenerated electrons/holes, leading to enhancing PEC efficiency. In this regard, $\mathrm{g}-\mathrm{C}_{3} \mathrm{~N}_{4}$ has been combined with a number of $p$-type semiconductors to construct photocathodes, such as $\mathrm{Cu}_{2} \mathrm{O}$ [132, 133], $\mathrm{NiO}$ [134], $\mathrm{BiOBr}$ [135], $\mathrm{CuGaSe}_{2}$ [136], and so on.

As a typical $p$-type semiconductor, $\mathrm{Cu}_{2} \mathrm{O}$ is an attractive photocathode material for PEC water splitting process because of its direct band gap of $\sim 2.0 \mathrm{eV}$ as well as the suitable VB band and CB potentials for water splitting $[9,132,133]$. A theoretical research manifests that a photocurrent density of $14.7 \mathrm{~mA} \mathrm{~cm}^{-2}$ and the solar-to-hydrogen conversion efficiency of $18 \%$ could be obtained on a $\mathrm{Cu}_{2} \mathrm{O}$ photocathode $[137,138]$. However, the $\mathrm{Cu}_{2} \mathrm{O}$ photocathode still has two main drawbacks for practical application: 1) the high recombination rate of photogenerated electrons and holes, and 2) the serious photo-corrosion in electrolyte solution $[132,139]$. Due to the compatibility between VB and $\mathrm{CB}$ of $\mathrm{g}-\mathrm{C}_{3} \mathrm{~N}_{4}$ and $\mathrm{Cu}_{2} \mathrm{O}, \mathrm{g}-\mathrm{C}_{3} \mathrm{~N}_{4}$ can be coupled with $\mathrm{Cu}_{2} \mathrm{O}$ to form the type II heterojunctions [140], which not only accelerates the separation of photogenerated electron and 
hole pairs, but also acts as a protection layer to avoid the photo-corrosion of $\mathrm{Cu}_{2} \mathrm{O}$.

Recently, a $\mathrm{Cu}_{2} \mathrm{O}$ foam film was modified by $\mathrm{g}-\mathrm{C}_{3} \mathrm{~N}_{4}$ nanosheets to form the $\mathrm{g}-\mathrm{C}_{3} \mathrm{~N}_{4} / \mathrm{Cu}_{2} \mathrm{O}$ heterojunctions through a simple dip-coating method (Figure 14a-c) [132]. The $n$-type $\mathrm{g}_{-} \mathrm{C}_{3} \mathrm{~N}_{4}$ did not change the $p$-type characteristic of $\mathrm{Cu}_{2} \mathrm{O}$ for this $\mathrm{Cu}_{2} \mathrm{O}$ foam/g- $\mathrm{C}_{3} \mathrm{~N}_{4}$ composite film, and the composite film produced a cathode current under AM 1.5 illumination (Figure 14d). Therefore, the $\mathrm{Cu}_{2} \mathrm{O}$ foam/g- $\mathrm{C}_{3} \mathrm{~N}_{4}$ composite film was suitable to be a photocathode for PEC water splitting Particularly, this $\mathrm{Cu}_{2} \mathrm{O}$ foam/g- $\mathrm{C}_{3} \mathrm{~N}_{4}$ composite film also showed a higher photocurrent density ( -3 $\left.\mathrm{mA} \mathrm{cm}{ }^{-2}\right)$ than $\mathrm{Cu}_{2} \mathrm{O}$ foam photocathode $\left(-2.5 \mathrm{~mA} \mathrm{~cm}^{-2}\right)$ at $-0.1 \mathrm{~V}$ vs. RHE under AM 1.5 illumination, which was resulted from the increased separation efficiency of photogenerated electron/hole pairs.

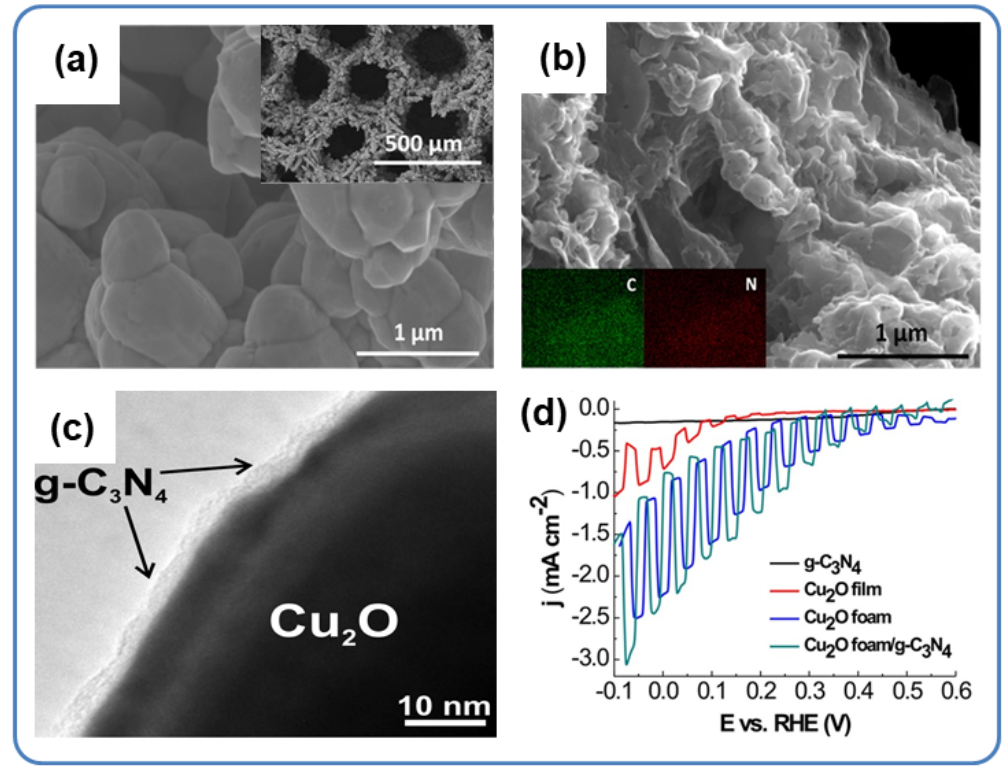

Figure 14 (1.5-column). Surface SEM image of (a) $\mathrm{Cu}_{2} \mathrm{O}$ foam and (b) $\mathrm{Cu}_{2} \mathrm{O}$ foam/g- $\mathrm{C}_{3} \mathrm{~N}_{4}$ composites. Inset in (a) is low-resolution SEM image of $\mathrm{Cu}_{2} \mathrm{O}$ foam surface. Inset in $\mathrm{b}$ is the corresponding EDS mapping of $\mathrm{Cu}_{2} \mathrm{O}$ foam/g- $\mathrm{C}_{3} \mathrm{~N}_{4}$ composites. (c) TEM image of $\mathrm{Cu}_{2} \mathrm{O} / \mathrm{g}-\mathrm{C}_{3} \mathrm{~N}_{4}$ heterojunctions. (d) LSV curves of $\mathrm{g}-\mathrm{C}_{3} \mathrm{~N}_{4}, \mathrm{Cu}_{2} \mathrm{O}$ film, $\mathrm{Cu}_{2} \mathrm{O}$ foam and $\mathrm{Cu}_{2} \mathrm{O}$ foam/g- $\mathrm{C}_{3} \mathrm{~N}_{4}$ films under $\mathrm{AM} 1.5$ illumination. Reprinted from ref. [132] with permission.

Apart from $\mathrm{Cu}_{2} \mathrm{O}$, another important $p$-type semiconductor is $\mathrm{NiO}$, which has also been widely 
used as photocathode materials for PEC water splitting. Similar to $\mathrm{Cu}_{2} \mathrm{O}$, the recombination of photogenerated electron/hole pairs also reduces its PEC efficiency. Besides, the large band gap of $\mathrm{NiO}(\sim 3.4 \mathrm{eV})$ further limits its visible light absorption [141-143]. To solve these issues, $\mathrm{g}-\mathrm{C}_{3} \mathrm{~N}_{4}$ has been incorporated with $\mathrm{NiO}$, to suppress the recombination of the photogenerated electrons/holes and to expand the light adsorption range at the same time, which functions on the basis of the type II heterojunction mechanism.

To achieve this, the $\mathrm{NiO} / \mathrm{g}-\mathrm{C}_{3} \mathrm{~N}_{4}$ composite films have been fabricated by a facile thermal polycondensation technology [134]. This $\mathrm{NiO} / \mathrm{g}-\mathrm{C}_{3} \mathrm{~N}_{4}$ composite film is suit to an effective photocathode (Figure 15a). Importantly, $\mathrm{NiO} / \mathrm{g}-\mathrm{C}_{3} \mathrm{~N}_{4}$ composite films not only expand the light absorption range (Figure 15b), but also accelerate the separation of photogenerated electrons and holes due to the formation of $\mathrm{NiO} / \mathrm{g}-\mathrm{C}_{3} \mathrm{~N}_{4}$ type II heterojunctions (Figure 14c-e). Consequently, the photocurrent density of $\mathrm{NiO} / \mathrm{g}-\mathrm{C}_{3} \mathrm{~N}_{4}$ composite film was greatly increased to $\sim 0.02 \mathrm{~mA} \mathrm{~cm}^{-2}$ at $0 \mathrm{~V}$ vs. RHE, which was almost 20 and 10 times higher than that of $g-\mathrm{C}_{3} \mathrm{~N}_{4}$ and $\mathrm{NiO}$ films, respectively (Figure 15f).
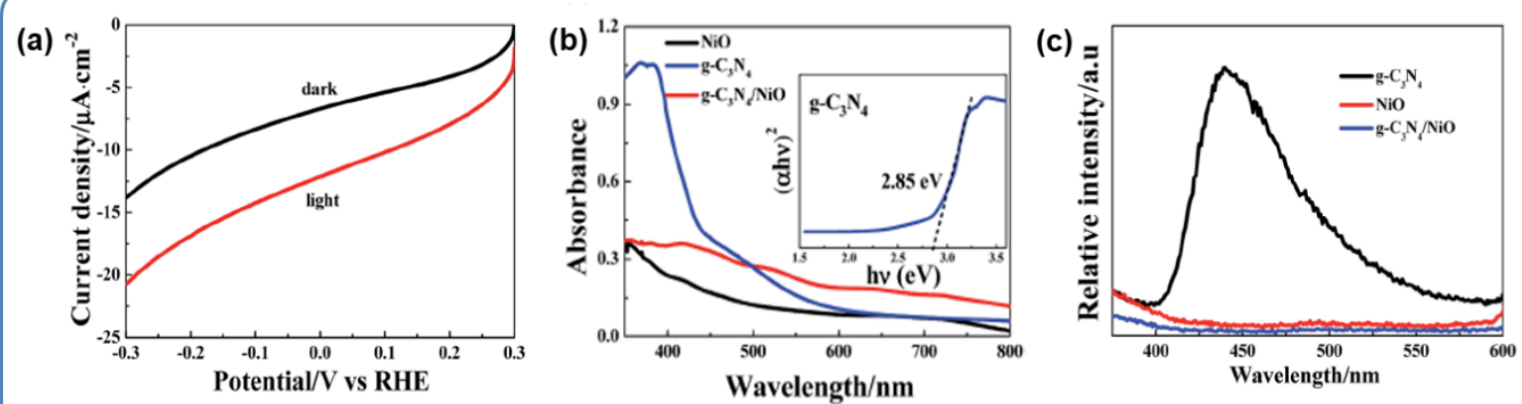

(d)

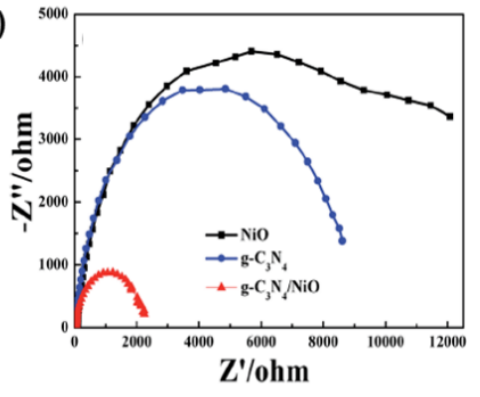

(e)

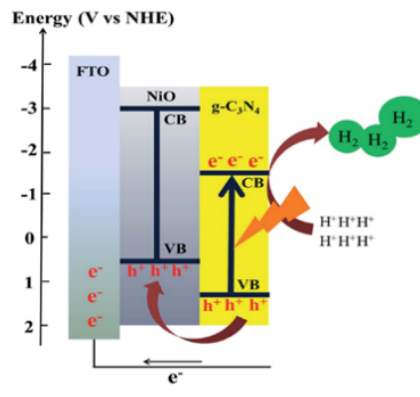

(f)

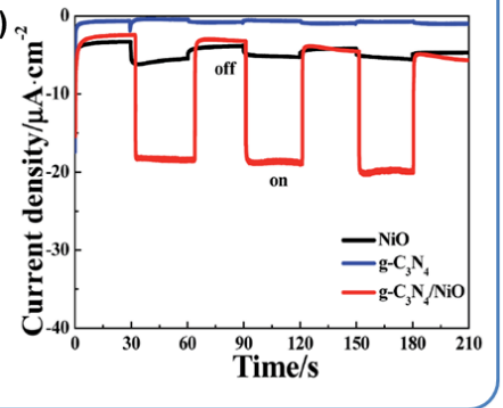


Figure 15 (2-column). (a) LSV curves of $\mathrm{NiO} / \mathrm{g}-\mathrm{C}_{3} \mathrm{~N}_{4}$ composite film photocathode under a $300 \mathrm{~W} \mathrm{Xe}$ arc lamp irradiation or dark condition. (b) UV-vis absorption spectra, (c) PL spectra and (d) Nyquist plots of g- $\mathrm{C}_{3} \mathrm{~N}_{4}, \mathrm{NiO}$, and $\mathrm{NiO} / \mathrm{g}-\mathrm{C}_{3} \mathrm{~N}_{4}$ composite films. (e) Mechanism illustration of $\mathrm{PEC} \mathrm{H}_{2}$ generation using $\mathrm{NiO} / \mathrm{g}-\mathrm{C}_{3} \mathrm{~N}_{4}$ composite film photocathode. (f) Photocurrent density $v$ s. times curves of $g-\mathrm{C}_{3} \mathrm{~N}_{4}, \mathrm{NiO}$, and $\mathrm{NiO} / \mathrm{g}-\mathrm{C}_{3} \mathrm{~N}_{4}$ film photocathodes at $0 \mathrm{~V} v s$. RHE under a $300 \mathrm{~W}$ Xe arc lamp irradiation. Reprinted from ref. from ref. [134] with permission.

Apart from the $p$-type semiconductors, graphdiyne (GDY) can also be compounded with $\mathrm{g}-\mathrm{C}_{3} \mathrm{~N}_{4}$ as the efficient photocathodes for PEC water splitting. Recently, a GDY/g- $\mathrm{C}_{3} \mathrm{~N}_{4}$ composite nanosheet array with 2D/2D heterojunctions has been fabricated by a simple solvothermal reaction between GDY nanosheets array and $\mathrm{g}-\mathrm{C}_{3} \mathrm{~N}_{4}$ nanosheets (Figure 16a-c). Importantly, the excellent hole-transfer property owned by GDY can speed the separation rate of photogenerated electrons/holes. Moreover, the ultrathin structure of 2D/2D heterojunctions between GDY and g- $\mathrm{C}_{3} \mathrm{~N}_{4}$ shorten the transfer distance of holes from $\mathrm{g}-\mathrm{C}_{3} \mathrm{~N}_{4}$ to GDY. Under the synergistic effect of above reasons, an increment of approximate $700 \%$ in electron life time $\left(610 \mu\right.$ s for GDY/g- $\mathrm{C}_{3} \mathrm{~N}_{4}$ photocathode) and enhancement of about $300 \%$ on photocurrent density $\left(-98 \mu \mathrm{A} \mathrm{cm}{ }^{-2}\right.$ for GDY/g- $\mathrm{C}_{3} \mathrm{~N}_{4}$ photocathode) were achieved compared to those of pure $\mathrm{g}-\mathrm{C}_{3} \mathrm{~N}_{4}$ photocathode (electron life time of $88 \mu$ s and photocurrent density of $-32 \mu \mathrm{A} \mathrm{cm}^{-2}$ ), respectively (Figure 16d and e) $[144]$. 


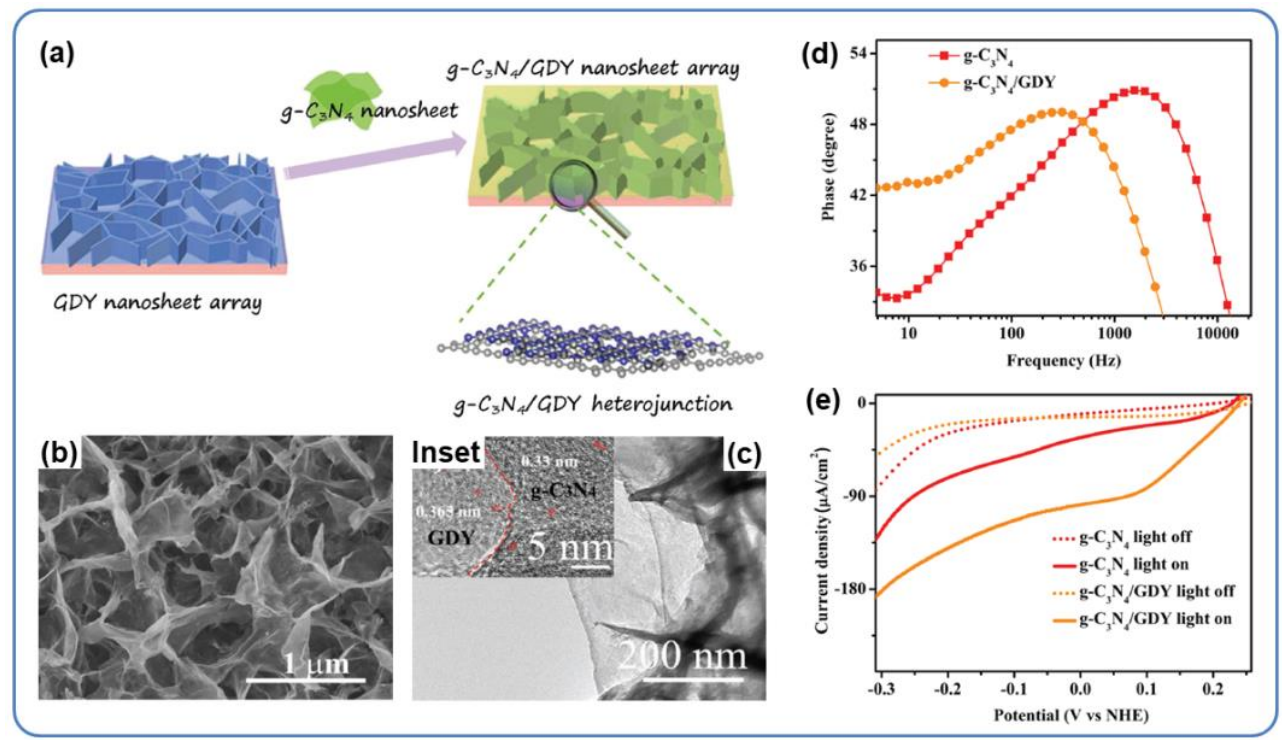

Figure 16 (2-column). (a) Schematic illustration for the construction of GDY/g- $\mathrm{C}_{3} \mathrm{~N}_{4}$ composite nanosheet array with 2D/2D heterojunctions. (b) SEM image of GDY/g- $\mathrm{C}_{3} \mathrm{~N}_{4}$ composite nanosheet array. (c) TEM image of ultrathin 2D/2D heterojunctions between GDY and $\mathrm{g}-\mathrm{C}_{3} \mathrm{~N}_{4}$. The inset is the HR-TEM image for GDY/g- $\mathrm{C}_{3} \mathrm{~N}_{4}$. (d) Bode phase plots of g- $\mathrm{C}_{3} \mathrm{~N}_{4}$ and g-C $\mathrm{C}_{3} \mathrm{~N}_{4} / \mathrm{GDY}$ photocathodes. (e) LSV curves of $\mathrm{g}-\mathrm{C}_{3} \mathrm{~N}_{4}$ and g- $\mathrm{C}_{3} \mathrm{~N}_{4} / \mathrm{GDY}$ photocathodes measured under dark and light. Reprinted from ref. [144] with permission.

For $\mathrm{g}-\mathrm{C}_{3} \mathrm{~N}_{4}$-based composite films, not only the recombination of photogenerated electrons/ holes can be suppressed, but also the visible light absorption scope can be expanded due to the effect of heterojunctions (Type II and Z-scheme). Therefore, the design of the $\mathrm{g}_{-} \mathrm{C}_{3} \mathrm{~N}_{4}$-based composite films with the desired heterojunctions can become a promising strategy for reaching the efficient $\mathrm{g}-\mathrm{C}_{3} \mathrm{~N}_{4}$-based photoelectrodes for PEC water splitting.

\section{Summary, Challenge and Outlook}

As a type of metal-free semiconducting materials, $\mathrm{g}-\mathrm{C}_{3} \mathrm{~N}_{4}$ has exhibited a versatile ability in photo(electro)- and especially PEC catalysis materials [145-148]. In this review, we have summarized the latest process in the $\mathrm{g}-\mathrm{C}_{3} \mathrm{~N}_{4}$-based films as the photoelectrodes (photoanodes and photocathodes) materials for PEC water splitting. As mentioned, although $g-\mathrm{C}_{3} \mathrm{~N}_{4}$ shows a number of advantages for PEC water splitting application, there are still many challenges remaining to be 
addressed, such as the difficulty in preparation of high-quality films, limited visible-light absorption up to $450 \mathrm{~nm}$, high recombination rate of photogenerated electron/hole pairs, and low electrical conductivity. All of these greatly hinder the further improvement of $\mathrm{g}-\mathrm{C}_{3} \mathrm{~N}_{4}$-based films in PEC water splitting for hydrogen generation.

High-quality g- $\mathrm{C}_{3} \mathrm{~N}_{4}$-based films are critical components in the photoelectrodes in the PEC water splitting process. Specifically, the $\mathrm{g}-\mathrm{C}_{3} \mathrm{~N}_{4}$ films should be uniform, continuous, and a good contact with the substrates. However, the poor dispersibility/solubility of $g-\mathrm{C}_{3} \mathrm{~N}_{4}$ closes the door for us to obtain the high-quality g- $\mathrm{C}_{3} \mathrm{~N}_{4}$-based films by the fairly mature top-down approaches. As a result, the novel bottom-up approaches, including TVC, microcontact-printing-assisted access, solvothermal route, and direct growth, have been developed to fabricate $\mathrm{g}-\mathrm{C}_{3} \mathrm{~N}_{4}$ films with a high quality. The bottom-up methods ingeniously avoid the poor dispersibility/solubility issue of $g-\mathrm{C}_{3} \mathrm{~N}_{4}$ that usually exists in the top-down approaches for $\mathrm{g}-\mathrm{C}_{3} \mathrm{~N}_{4}$ preparation. Consequently, they commonly provide higher-quality g- $\mathrm{C}_{3} \mathrm{~N}_{4}$ films and better PEC water splitting performance than the top-down approaches (Figure 17).

Apart from the new preparation technologies, the modification of $\mathrm{g}-\mathrm{C}_{3} \mathrm{~N}_{4}$ films, such as functional groups grafting, heteroatoms doping, and $\mathrm{g}-\mathrm{C}_{3} \mathrm{~N}_{4}$-based composite films designing, are also effective to extend the visible-light absorption, reduce the recombination of photogenerated electrons and holes, and increase the electrical conductivity, thus enhancing their PEC performance. Compared with pristine $\mathrm{g}-\mathrm{C}_{3} \mathrm{~N}_{4}$ films, the modified $\mathrm{g}-\mathrm{C}_{3} \mathrm{~N}_{4}$-based films usually show a better PEC water splitting performance (Figure 17). 


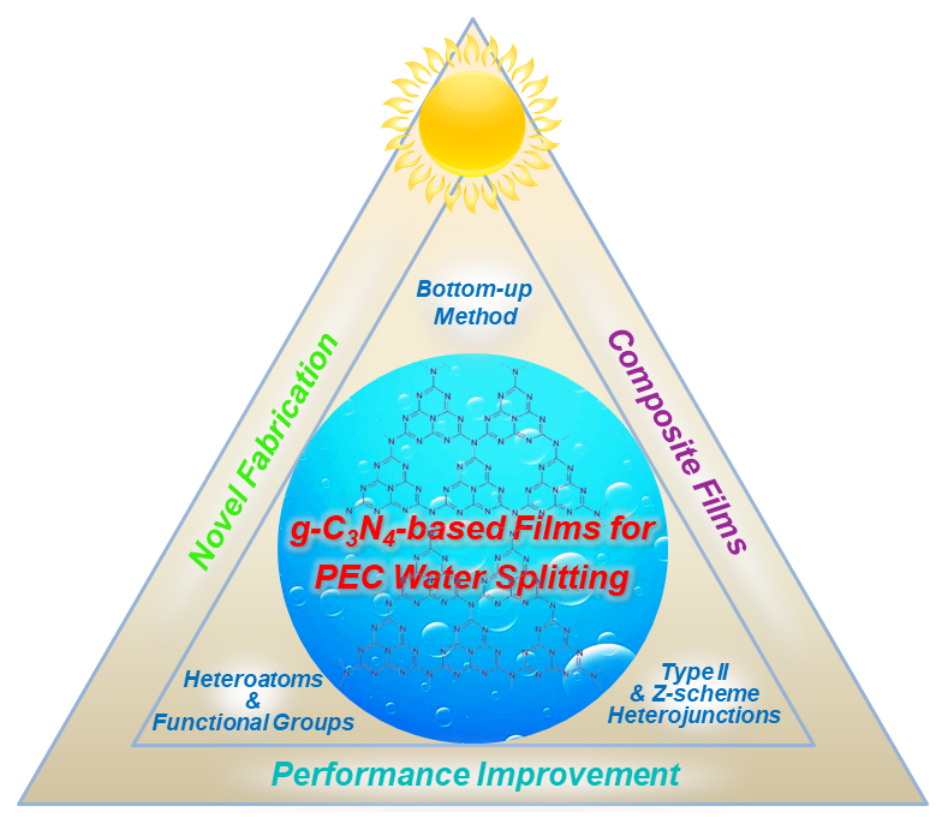

Figure 17 (1.5-column). Key factors in $\mathrm{g}_{-} \mathrm{C}_{3} \mathrm{~N}_{4}$ films for advanced $\mathrm{PEC}$ water splitting.

Although these breakthroughs have been proven effective in promoting the PEC water splitting performance of the $\mathrm{g}-\mathrm{C}_{3} \mathrm{~N}_{4}$-based materials, the current solar-to-hydrogen conversion efficiency is not enough to develop a commercial PEC water splitting device, the efficiency needs to be further improved to greater than $10 \%$ to reach a feasible commercialization level [149-151]. Thus, efforts should still be made on some key points, which are essential to achieve the further improvement of the materials, as following:

1) The bottom-up methods should be further modified, in terms of the starting materials design, reactor parameters optimization, and substrates pre-treatment for achieving the $\mathrm{g}_{-} \mathrm{C}_{3} \mathrm{~N}_{4}$ film photoelectrodes with satisfactory PEC efficiency.

2) More types of functional groups and heteroatoms should be explored and introduced into the g- $\mathrm{C}_{3} \mathrm{~N}_{4}$ frameworks to more efficiently enhance the PEC water splitting performance. Plenty of theoretical and experimental research has indicated that the introduction of functional groups or heteroatoms into g- $\mathrm{C}_{3} \mathrm{~N}_{4}$ frame can adjust its intrinsic $\pi$ conjugated structure, leading to significant changes of electronic state, band structure, and optical/electrical properties [152-156]. Additionally, 
synergistic effects of functional groups and heteroatoms should be fully utilized by simultaneous introducing them into $\mathrm{g}-\mathrm{C}_{3} \mathrm{~N}_{4}$ films.

3) The defects play a non-negligible role on $\mathrm{g}-\mathrm{C}_{3} \mathrm{~N}_{4}$-based PEC water splitting process. Specifically, the defects in $\mathrm{g}-\mathrm{C}_{3} \mathrm{~N}_{4}$ films bring both the positive and negative effects on PEC performance of $\mathrm{g}-\mathrm{C}_{3} \mathrm{~N}_{4}$-based photoelectrodes simultaneously. On the one hand, the artificial introduction of defects into $\mathrm{g}-\mathrm{C}_{3} \mathrm{~N}_{4}$ films markedly enhances the optical and electrical properties [80, 88]. On the other hand, excessive defects may become the recombination sites of photogenerated electrons and holes, which significantly reduce the PEC efficiency [37]. Therefore, the defects in g- $\mathrm{C}_{3} \mathrm{~N}_{4}$ films should be precisely controlled in order to achieve the maximizing improvement on PEC performance of $\mathrm{g}-\mathrm{C}_{3} \mathrm{~N}_{4}$-based photoelectrodes.

4) Although many types of $\mathrm{g}-\mathrm{C}_{3} \mathrm{~N}_{4}$-based composite films have been utilized as photoelectrodes for PEC water splitting, their morphologies were still not well controllable. For example, the photoelectrodes on certain nanostructures, such as nanotubes, nanorods, nanowires array, can be more effectively separated due to the geometrical effects. Besides, other well-designed $\mathrm{g}-\mathrm{C}_{3} \mathrm{~N}_{4}$-based heterostructures, for example, multifarious function layers, $\mathrm{g}-\mathrm{C}_{3} \mathrm{~N}_{4}$ nanosheets wrapped morphology, 2D/2D nanostructures, and introduction of co-catalyst also could exhibit the excellent PEC properties due to their novel nanostructures [157-163]. Therefore, design and fabrication of $\mathrm{g}-\mathrm{C}_{3} \mathrm{~N}_{4}$-based composite films with these nanostructures could provide a higher PEC water splitting performance than the uniform films.

5) Single-atom catalysis (SAC) and MXene materials have become two major research hotspots in energy conversion fields in recent years due to their outstanding photo(electro)catalytic and PEC performances [164-167]. Therefore, the SAC and MXene should be introduced into $\mathrm{g}_{-} \mathrm{C}_{3} \mathrm{~N}_{4}$-based photoelectrodes in order to achieve a high-performance water splitting process. 
6) The stability of $\mathrm{g}-\mathrm{C}_{3} \mathrm{~N}_{4}$-based photoelectrodes is very important for the large-scale and long-term application. To achieve a stable run, the modified technologies should be further researched, including obtaining strong adhesion of $\mathrm{g}-\mathrm{C}_{3} \mathrm{~N}_{4}$ films on substrates and protecting g- $\mathrm{C}_{3} \mathrm{~N}_{4}$ from photo- or chemical-corrosion by protective layers in the practical PEC water splitting process.

To summarize, although there are a mass of urgent issues, the prospect of $g-\mathrm{C}_{3} \mathrm{~N}_{4}$-based PEC water splitting for hydrogen generation is still hopeful due to the excellent and unique physicochemical properties owned by $\mathrm{g}-\mathrm{C}_{3} \mathrm{~N}_{4}$ material. With further development of related researches, these obstacles that hinder the application of $\mathrm{g}-\mathrm{C}_{3} \mathrm{~N}_{4}$ films in PEC water splitting will be thoroughly overcome. At last, we believe that the $\mathrm{g}-\mathrm{C}_{3} \mathrm{~N}_{4}$ films can pave an avenue for us to achieve an efficient and stable PEC water splitting process.

\section{Acknowledgements}

This work was supported by Developed and Applied Funding of Tianjin Normal University (135202XK1702), and Australian Research Council (ARC) through Discovery Early Career Researcher Awards (DECRA, DE170100871). 


\section{References}

[1] L.M. Dai, D.W. Chang, J.B. Baek, W. Lu, Carbon nanomaterials for advanced energy conversion and storage, Small 8 (8) (2012) 1130-1166.

[2] Y.T. Gong, J. Wang, Z.Z. Wei, P.F. Zhang, H.R. Li, Y. Wang, Combination of carbon nitride and carbon nanotubes: synergistic catalysts for energy conversion, Chemsuschem. 7 (8) (2014) 2303-2309.

[3] W.J. Ong, L.L. Tan, Y.H. Ng, S.T. Yong, S.P. Chai, Graphitic carbon nitride $\left(\mathrm{g}_{-} \mathrm{C}_{3} \mathrm{~N}_{4}\right)$-based photocatalysts for artificial photosynthesis and environmental remediation: are we a step closer to achieving sustainability? Chem. Rev. 116 (12) 2016 7159-7329.

[4] P. Zhou, J.G. Yu, M. Jaroniec, All-solid-state Z-scheme photocatalytic systems, Adv. Mater. 26 (29) (2014) 4920-4935.

[5] J. Du, Z.L. Du, J.S. Hu, Z.X. Pan, Q. Shen, J.K. Sung, D.H. Long, H. Dong, L.T. Sun, X.H. Zhong, Zn-Cu-In-Se quantum dot solar cells with a certified power conversion efficiency of 11.6\%, J. Amer. Chem. Soc. 138 (12) (2016) 4201-4209.

[6] J.F. DeCarolis, D.W. Keith, The real cost of wind energy, Science 294 (5544) (2001) 1000-1001.

[7] Z.L. Wang, T. Jiang, L.Xu, Toward the blue energy dream by triboelectric nanogenerator networks, Nano Energ. 39 (2017) 9-23.

[8] B. Rausch, M.D. Symes, G. Chisholm, L. Cronin, Decoupled catalytic hydrogen evolution from a molecular metal oxide redox mediator in water splitting, Science 345 (6202) (2014) 1326-1330.

[9] Y. Yang, S.W. Niu, D.D. Han, T.Y. Liu, G.M. Wang, Y. Li, Progress in developing metal oxide nanomaterials for photoelectrochemical water splitting, Adv. Energ. Mater. 7 (19) (2017) 
1700555.

[10] C. Marchal, M. Behr, F. Vigneron, V. Caps, V. Keller, Au/TiO 2 photocatalysts prepared by solid grinding for artificial solar-light water splitting, New J. Chem. 40 (5) (2016) 4428-4435.

[11] A. Fujishima, K. Honda, Electrochemical photolysis of water at a semiconductor electrode, Nature 238 (5358) (1972) 37-38.

[12] S.H. Shen, S.A. Lindley, X.Y. Chen, J.Z. Zhang, Hematite heterostructures for photoelectrochemical water splitting: rational materials design and charge carrier dynamics, Energ. Environ. Sci., 9 (9) (2016) 2744-2775.

[13] M.R. Nellist, F.A.L. Laskowski, F.D. Lin, T.J. Mills, S.W. Boettcher, Semiconductorelectrocatalyst interfaces: theory, experiment, and applications in photoelectrochemical water splitting, Accounts. Chem. Res. 49 (4) (2016) 733-740.

[14] C.R. Jiang, S.J.A. Moniz, A.Q. Wang, T. Zhang, J.W. Tang, Photoelectrochemical devices for solar water splitting-materials and challenges, Chem. Soc. Rev. 46 (15) (2017) 4645-4660.

[15] J. Joy, J. Mathew, S.C. George, Nanomaterials for photoelectrochemical water splittingreview, Int. J. Hydrogen. Energ. 43 (10) (2018) 4804-4817.

[16] S. Kumar, K. Ojha, A.K. Ganguli, Interfacial charge transfer in photoelectrochemical processes, Adv. Mater. Interfaces 4 (7) (2017) 1600981.

[17] Z.D. Li, C.H. Yao, Y.H. Yu, Z.Y. Cai, X.D. Wang, Highly efficient capillary photoelectrochemical water splitting using cellulose nanofiber-templated $\mathrm{TiO}_{2}$ photoanodes, Adv. Mater. 26 (14) (2014) 2262-2267.

[18] C.Y. Lee, A.C. Taylor, S. Beirne, G.G. Wallace, 3D-printed conical arrays of $\mathrm{TiO}_{2}$ electrodes for enhanced photoelectrochemical water splitting, Adv. Energ. Mater. 7 (21) (2017) 1701060.

[19] C.C. Hao, W.Z. Wang, R. Zhang, B. Zou, H.L. Shi, Enhanced photoelectrochemical water 
splitting with $\mathrm{TiO}_{2} @ \mathrm{Ag}_{2} \mathrm{O}$ nanowire arrays via $\mathrm{P}-\mathrm{N}$ heterojunction formation, Sol. Energ. Mater. Sol. Cells 174 (2018) 132-139.

[20] C.X. Guo, Y.Q. Dong, H.B. Yang, C.M. Li, Graphene quantum dots as a green sensitizer to functionalize $\mathrm{ZnO}$ nanowire arrays on F-doped $\mathrm{SnO}_{2}$ glass for enhanced photoelectrochemical water splitting, Adv. Energ. Mater. 3 (8) (2013) 997-1003.

[21] T.T. Yang, J.W. Xue, H. Tan, A.J. Xie, S.K. Li, W.S. Yan, Y.H. Shen, Highly ordered $\mathrm{ZnO} / \mathrm{ZnFe}_{2} \mathrm{O}_{4}$ inverse opals with binder-free heterojunction interfaces for high-performance photoelectrochemical water splitting, J. Mater. Chem. A. 6 (3) (2018) $1210-1218$.

[22] Q. Liu, D.Y. Ding, C.Q. Ning, X.W. Wang, Nonstoichiometric $\mathrm{In}_{2} \mathrm{O}_{3}$ nanorods/black Ti-Ni-O nanotubes heterojunction photoanode for high-efficiency photoelectrochemical water splitting, Sol. Energ. Mater. Sol. Cells. 145 (2016) 382-390.

[23] M. Li, X.L. Tu, Y.J. Su, J. Lu, J. Hu, B.F. Cai, Z.H. Zhou, Z. Yang, Y.F. Zhang, Controlled growth of vertically aligned ultrathin $\operatorname{In}_{2} \mathrm{~S}_{3}$ nanosheet arrays for photoelectrochemical water splitting, Nanoscale 10 (3) (2018) 1153-1161.

[24] X.Y. Xu, G. Zhou, X.F. Dong, J.G. Hu, Interface band engineering charge transfer for 3D $\mathrm{MoS}_{2}$ photoanode to boost photoelectrochemical water splitting, ACS Sustain. Chem. Eng. 5 (5) (2017) 3829-3836.

[25] Y.J. Ma, Y. Liu, Y. Bian, A.Q. Zhu, Y. Yang, J. Pan, Controlling shape anisotropy of hexagonal CdS for highly stable and efficient photocatalytic $\mathrm{H}_{2}$ evolution and photoelectrochemical water splitting, J. Colloid Interface Sci. 518 (2018) 140-148.

[26] B. Wang, Z.F. Liu, J.H. Han, T.T. Hong, J. Zhang, Y.J. Li, T. Cui, Hierarchical graphene/CdS/Ag $2 \mathrm{~S}$ sandwiched nanofilms for photoelectrochemical water splitting. 
Electrochim. ACTA 176 (2015) 334-343.

[27] Y.W. Kim, S. Cha, I. Kwak, I.S. Kwon, K. Park, C.S. Jung, E.H. Cha, J. Park, Surface-modified $\mathrm{Ta}_{3} \mathrm{~N}_{5}$ nanocrystals with boron for enhanced visible-light-driven photoelectrochemical water splitting, ACS Appl. Mater. Interfaces 9 (42) (2017) 36715-36722.

[28] M.A. Hassan, J.H. Kang, M.A. Johar, J.S. Ha, S.W. Ryu, High-performance ZnS/GaN heterostructure photoanode for photoelectrochemical water splitting applications, ACTA Mater. 146 (2018) 171-175.

[29] J. Kamimura, P. Bogdanoff, M. Ramsteiner, L. Geelhaar, H. Riechert, Photoelectrochemical properties of InN nanowire photoelectrodes for solar water splitting, Semicond. Sci. Tech. 31 (7) (2016) 074001.

[30] Y.X. Yin, Z.G. Jin, F. Hou, Enhanced solar water-splitting efficiency using core/sheath heterostructure $\mathrm{CdS} / \mathrm{TiO}_{2}$ nanotube arrays, Nanotech. 18 (49) (2007) 495608.

[31] B. Sun, T.L. Shi, X.H. Tan, Z.Y. Liu, Y.N. Wu, G.L. Liao, Iridium oxide modified $\mathrm{CdSe} / \mathrm{CdS} / \mathrm{TiO}_{2}$ nanorods for efficient and stable photoelectrochemical water splitting, Mater. Today Pro. 3 (2) (2016) 443-448.

[32] R. Ahmed, Y. Xu, G. Zangari, Water splitting vs. sulfite oxidation: an assessment of photoelectrochemical performance of $\mathrm{TiO}_{2}$ nanotubes modified by $\mathrm{CdS} / \mathrm{CdSe}$ nanoparticles. Electrochim. ACTA 259 (2018) 1095-1103.

[33] X.C. Wang, K. Maeda, A. Thomas, K. Takanabe, G. Xin, J.M. Carlsson, K. Domen, M. Antonietti, A metal-free polymeric photocatalyst for hydrogen production from water under visible light, Nat. Mater. 8 (1) (2009) 76-80.

[34] R. Godin, Y. Wang, M.A. Zwijnenburg, J.W. Tang, J.R. Durrant, Time-resolved spectroscopic investigation of charge trapping in carbon nitrides photocatalysts for hydrogen generation, J. 
Amer. Chem. Soc. 139 (14) (2017) 5216-5224.

[35] B.C. Zhu, L.Y. Zhang, B. Cheng, J.G. Yu, First-principle calculation study of tri-s-triazine-based g- $\mathrm{C}_{3} \mathrm{~N}_{4}$ : a review, Appl. Catal. B Environ. 224 (2018) 983-999.

[36] A. Naseri, M. Samadi, A. Pourjavadi, A.Z. Moshfegh, S. Ramakrishna, Graphitic carbon nitride $\left(\mathrm{g}-\mathrm{C}_{3} \mathrm{~N}_{4}\right)$-based photocatalysts for solar hydrogen generation: recent advances and future development directions, J. Mater. Chem. A 5 (15) (2017) 23406-234333.

[37] M. Volokh, G.M. Peng, J. Barrio, M. Shalom, Carbon nitride materials for water splitting photoelectrochemical cells, Angew. Chem. Int. Edi. 2018 10.1002/anie.201806514.

[38] G.M. Wang, Y.H. Ling, H.Y. Wang, X.H. Lu, Y. Li, Chemically modified nanostructures for photoelectrochemical water splitting, J. Photochem. Photobio. C Photochem. Rev. 19 (2014) $35-51$.

[39] H.M. Chen, C.K. Chen, R.S. Liu, L. Zhang, J.J. Zhang, D.P. Wilkinson, Nano-architecture and material designs for water splitting photoelectrodes, Chem. Soc. Rev. 41 (17) (2012) $5654-5671$.

[40] M.G. Walter, E.L. Warren, J.R. McKone, S.W. Boettcher, Q.X. Mi, E.A. Santori, N.S. Lewis, Solar water splitting cells, Chem. Rev. 110 (11) (2010) 6446-6473.

[41] S.N.H. Jaffa, L.J. Minggu, K. Arifin, M.B. Kassim, W.R.D. Wan, Natural dyes as $\mathrm{TiO}_{2}$ sensitizers with membranes for photoelectrochemical water splitting: an overview, Renew. Sust. Energ. Rev. 78 (2017) 698-709.

[42] Y.Z. Hong, Z.Y. Fang, B.X. Yin, B.F. Luo, Y. Zhao, W.D. Shi, C.S. Li, A visible-light-driven heterojunction for enhanced photocatalytic water splitting over $\mathrm{Ta}_{2} \mathrm{O}_{5}$ modified $\mathrm{g}-\mathrm{C}_{3} \mathrm{~N}_{4}$ photocatalyst. Int. J. Hydrogen. Energ. 42 (10) (2017) 6738-6745.

[43] F. Dong, Z.W. Zhao, T. Xiong, Z.L. Ni, W.D. Zhang, Y.J. Sun, W.-K. Ho, In situ construction of 
g- $\mathrm{C}_{3} \mathrm{~N}_{4} / \mathrm{g}-\mathrm{C}_{3} \mathrm{~N}_{4}$ metal-free heterojunction for enhanced visible-light photocatalysis, ACS Appl. Mater. Interfaces 5 (21) (2013) 11392-11401.

[44] X.C. Wang, S. Blechert, M. Antonietti, Polymeric graphitic carbon nitride for heterogeneous photocatalysis, ACS Catal. 2 (8) (2012) 1596-1606.

[45] D.J. Martin, P.J.T. Reardon, S.J.A. Moniz, J.W. Tang, Visible light-driven pure water splitting by a nature-inspired organic semiconductor-based system, J. Amer. Chem. Soc. 136 (36) (2014) $12568-12571$.

[46] L. Zhou, L.Z. Wang, J.L. Zhang, J.Y. Lei, Y.D. Liu, The preparation and applications of $\mathrm{g}_{-} \mathrm{C}_{3} \mathrm{~N}_{4} / \mathrm{TiO}_{2}$ heterojunction catalysts-a review. Res. Chem. Intermediat. 43 (4) (2017) 2081-2101.

[47] G. Mamba, A.K. Mishra, Graphitic carbon nitride $\left(\mathrm{g}-\mathrm{C}_{3} \mathrm{~N}_{4}\right)$ nanocomposites: a new and exciting generation of visible light driven photocatalysts for environmental pollution remediation, Appl. Catal. B Environ. 198 (2016) 347-377.

[48] L.B. Jiang, X.Z. Yuan, Y. Pan, J. Liang, G.M. Zeng, Z.B. Wu, H. Wang, Doping of graphitic carbon nitride for photocatalysis: a reveiw. Appl. Catal. B Environ. 217 (2017) 388-406.

[49] J.W. Fu, J.G. Yu, C.J. Jiang, B. Cheng, g- $\mathrm{C}_{3} \mathrm{~N}_{4}$-based heterostructured photocatalysts, Adv. Energ. Mater. 8 (3) (2018) 1701503.

[50] R. Abea, Recent progress on photocatalytic and photoelectrochemical water splitting under visible light irradiation. J. Photochem. Photobio. C Photochem. Rev. 11 (4) (2010) 179-209.

[51] L.M. Peter, K.G.U. Wijayantha, Photoelectrochemical water splitting at semiconductor electrodes: fundamental problems and new perspectives, Chemphyschem. 15 (10) (2014) 1983-1995.

[52] X.J. Shi, L.L. Cai, M. Ma, X.L. Zheng, J.H. Park, General characterization methods for 
photoelectrochemical cells for solar water splitting, Chemsuschem. 8 (19) (2015) 3192-3203.

[53] S.N. Ariffin, H.N. Lim, Z.A. Talib, A. Pandikumar, N.M. Huang, Aerosol-assisted chemical vapor deposition of metal oxide thin films for photoelectrochemical water splitting, Int. J. Hydrogen. Energ. 40 (5) (2015) 2115-2131.

[54] Y. Li, J.Z. Zhang, Hydrogen generation from photoelectrochemical water splitting based on nanomaterials, Laser Photonics Rev. 4 (4) 2010 517-528.

[55] X.K. Sun, X.H. Fu, T.T. You, Q.N. Zhang, L.Y. Xu, X.D. Zhou, H.L. Yuan, K.L. Liu, Investigation of photoelectrochemical water splitting for Mn-doped $\operatorname{In}_{2} \mathrm{O}_{3}$ film, Electronic Mater. Lett. 14 (6) (2018) 733-738.

[56] L. Shi, Z. Li, T.D. Dao, T. Nagao, Y. Yang, A synergistic interaction between isolated Au nanoparticles and oxygen vacancies in an amorphous black $\mathrm{TiO}_{2}$ nanoporous film: toward enhanced photoelectrochemical water splitting, J. Mater. Chem. A 6 (27) (2018) 12978-12984.

[57] S.C. Wang, T.W. He, J.H. Yun, Y.X. Hu, M. Xiao, A.J. Du, L.Z. Wang, New iron-cobalt oxide catalysts promoting $\mathrm{BiVO}_{4}$ films for photoelectrochemical water splitting, Adv. Funct. Mater. $28(34)(2018) 1802685$

[58] T. J. Jacobsson, Photoelectrochemical water splitting: an idea heading towards obsolescence? Energ. Envir. Sci. 11 (8) (2018) 1977-1979.

[59] J.N. Liu, Q.H. Jia, J.L. Long, X.X. Wang, Z.W. Gao, Q. Gu, Amorphous NiO as co-catalyst for enhanced visible-light-driven hydrogen generation over $\mathrm{g}-\mathrm{C}_{3} \mathrm{~N}_{4}$ photocatalyst, Appl. Catal. B Environ. 222 (2018) 35-43.

[60] Z.X. Qin, Y.B. Chen, Z.X. Huang, J.Z. Su, L.J. Guo, A bifunctional NiCoP-based core/shell cocatalyst to promote separate photocatalytic hydrogen and oxygen generation over graphitic carbon nitride, J. Mater. Chem. A 5 (36) (2017) 19025-19035. 
[61] H. Wang, B. Wang, Y.R. Bian, L.M. Dai, Enhancing photocatalytic activity of graphitic carbon nitride by Co doping with $\mathrm{P}$ and $\mathrm{C}$ for efficient hydrogen generation, ACS Appl. Mater. Interfaces 9 (26) (2017) 21730-21737.

[62] K. Li, F.Y. Su, W.D. Zhang, Modification of $\mathrm{g}-\mathrm{C}_{3} \mathrm{~N}_{4}$ nanosheets by carbon quantum dots for highly efficient photocatalytic generation of hydrogen, Appl. Sur. Sci. 375 (2016) 110-117.

[63] K. Schwinghammer, M.B. Mesch, V. Duppel, C. Ziegler, J. Senker, B.V. Lotsch, Crystalline carbon nitride nanosheets for improved visible-light hydrogen evolution, J. Amer. Chem. Soc. 136 (5) (2014) 1730-1733.

[64] K. Maeda, X.C. Wang, Y. Nishihara, D.L. Lu, M. Antonietti, K. Domen, Photocatalytic activities of graphitic carbon nitride powder for water reduction and oxidation under visible light, J. Phys. Chem. C 113 (12) (2009) 4940-4947.

[65] J.S. Zhang, M.W. Zhang, G.G. Zhang, X.C. Wang, Synthesis of carbon nitride semiconductors in sulfur flux for water photoredox catalysis, ACS Catal. 2 (6) (2012) 940-948.

[66] S. Kumar, S. Karthikeyan, A.F. Lee, G-C ${ }_{3} \mathrm{~N}_{4}$-based nanomaterials for visible light-driven photocatalysis, Catal. 8 (2) (2018) 74.

[67] M. Xiao, B. Luo, S.C. Wang, L.Z. Wang, Solar energy conversion on $\mathrm{g}-\mathrm{C}_{3} \mathrm{~N}_{4}$ photocatalyst: light harvesting, charge separation, and surface kinetics. J. Energ. Chem. 27 (4) (2018) $1111-1123$.

[68] D.L. Huang, X.L. Yan, M Yan., G.M. Zeng, C.Y. Zhou, J. Wan, M. Cheng, W.J. Xue, Graphitic carbon nitride-based heterojunction photoactive nanocomposites: applications and mechanism insight, ACS Appl. Mater. Interfaces 10 (25) (2018) 21035-21055.

[69] J.C. Bian, C. Huang, R.Q. Zhang, Graphitic carbon nitride film: an emerging star for catalytic and optoelectronic applications, Chemsuschem. 9 (19) (2016) 2723-2735. 
[70] S.B. Kokane, R. Sasikala, D.M. Phase, S.D. Sartale, $\operatorname{In}_{2} \mathrm{~S}_{3}$ nanoparticles dispersed on $\mathrm{g}_{-} \mathrm{C}_{3} \mathrm{~N}_{4}$ Nanosheets: role of heterojunctions in photoinduced charge transfer and photoelectrochemical and photocatalytic performance. J. Mater. Sci. 52 (17) (2017) 7077-7090.

[71] K. Li, X.Q. Zeng, S.M. Gao, L. Ma, Q.Y. Wang, H. Xu, Z.Y. Wang, B.B. Huang, Y. Dai, J. Lu, Ultrasonic-assisted pyrolyzation fabrication of reduced $\mathrm{SnO}_{2-\mathrm{x}} / \mathrm{g}-\mathrm{C}_{3} \mathrm{~N}_{4}$ heterojunctions: enhance photoelectrochemical and photocatalytic activity under visible LED light irradiation, Nano Res. 9 (7) (2016) 1969-1982.

[72] Y.J. Zhang, A. Thomas, M. Antonietti, X.C. Wang, Activation of carbon nitride solids by protonation: morphology changes, enhanced ionic conductivity, and photoconduction experiments, J. Amer. Chem. Soc. 131 (1) (2009) 50-51.

[73] X.J. Bai, L. Wang, R.L. Zong, Y.F. Zhu, Photocatalytic activity enhanced via g- $\mathrm{C}_{3} \mathrm{~N}_{4}$ nanoplates to nanorods, J. Phys. Chem. C 117 (19) (2013) 9952-9961.

[74] Y. Wang, X. Zhao, Y. Tian, Y.B. Wang, A.K. Jan, Y.T. Chen, Facile electrospinning synthesis of carbonized polyvinylpyrrolidone (PVP)/g- $\mathrm{C}_{3} \mathrm{~N}_{4}$ hybrid films for photoelectrochemical applications, Chem. Eur. J. 23 (2) (2017) 419-426.

[75] J.S. Zhang, M.W. Zhang, L.H. Lin, X.C. Wang, Sol processing of conjugated carbon nitride powders for thin-film fabrication, Angew. Chem. Int. Edi. 54 (21) (2015) 6297-6301.

[76] H. Miaom, G.W. Zhang, X.Y. Hu, J.L. Mu, T.X. Han, J. Fan, C.J. Zhu, L.X. Song, J.T. Bai, X. Hou, A novel strategy to prepare $2 \mathrm{D} g-\mathrm{C}_{3} \mathrm{~N}_{4}$ nanosheets and their photoelectrochemical properties, J. Alloy. Com. 690 (2017) 669-676.

[77] J.S. Xu, M. Shalom, Electrophoretic deposition of carbon nitride layers for photoelectrochemical applications, ACS Appl. Mater. Interfaces 8 (20) (2016) 13058-13063. 
[78] J.C. Bian, Q. Li, C. Huang, J.F. Li, Y. Guo, M. Zaw, R.Q. Zhang, Thermal vapor condensation of uniform graphitic carbon nitride films with remarkable photocurrent density for photoelectrochemical applications, Nano Energ. 2015, 15:353-361.

[79] X.W. Lv, M. Cao, L., W.N. Shi, M.K. Wang, Y. Shen, A new strategy of preparing uniform graphitic carbon nitride films for photoelectrochemical application, Carbon 117 (2017) 343-350.

[80] J.C. Bian, L.F. Xi, C. Huang, K.M. Lange, R.Q. Zhang, M. Shalom, Efficiency enhancement of carbon nitride photoelectrochemical cells via tailored monomers design, Adv. Energ. Mater. 6 (12) (2016) 1600263.

[81] J.C. Bian, L.F. Xi, J.F. Li, Z. Xiong, C. Huang, K.M. Lange, J.Y. Tang, M. Shalom, R.Q. Zhang, $\mathrm{C}=\mathrm{C} \pi$ bond modified graphitic carbon nitride films for enhanced photoelectrochemical cell performance, Chem. an Asian J. 12 (9) (2017) 1005-1012.

[82] X. Lu, Z.F. Liu, J.W. Li, J. Zhang, Z.G. Guo, Novel framework g- $\mathrm{C}_{3} \mathrm{~N}_{4}$ film as efficient photoanode for photoelectrochemical water splitting, Appl. Catal. B Environ. 209 (2017) $657-662$.

[83] J. Liu, H.Q. Wang, Z.P. Chen, H. Moehwald, S. Fiechter, R. van de Krol, L.P. Wen, L. Jiang, M. Antonietti, Microcontact-printing-assisted access of graphitic carbon nitride films with favorable textures toward photoelectrochemical application, Adv. Mater. 27 (4) (2015) 712-718.

[84] X.X. Xie, X.L. Fan, X.L. Huang, T. Wang, J.P. He, In situ growth of graphitic carbon nitride films on transparent conducting substrates via a solvothermal route for photoelectrochemical performance, RSC Adv. 6 (12) (2016) 9916-9922.

[85] Q. Gu, X.Z. Gong, Q.H. Jia, J.N. Liu, Z.W. Gao, X.X. Wang, J.L. Long, C. Xue, Compact 
carbon nitride based copolymer films with controllable thickness for photoelectrochemical water splitting, J. Mater. Chem. A 5 (36) (2017) 19062-19071.

[86] M. Shalom, S. Gimenez, F. Schipper, I. Herraiz-Cardona, J. Bisquert, M. Antonietti Controlled carbon nitride growth on surfaces for hydrogen evolution electrodes, Angew. Chem. Int. Edi. 53 (14) (2014) 3654-3658.

[87] L.J. Ye, S.J. Chen, Fabrication and high visible-light-driven photocurrent response of g- $\mathrm{C}_{3} \mathrm{~N}_{4}$ film: the role of thiourea, Appl. Sur. Sci. 389 (2016) 1076-1083.

[88] J.S. Xu, S.W. Cao, T. Brenner, X.F. Yang, J.G. Yu, M. Antonietti, M. Shalom, Supramolecular chemistry in molten sulfur: preorganization effects leading to marked enhancement of carbon nitride photoelectrochemistry, Adv. Funct. Mater. 25 (39) (2015) 6265-6271.

[89] W.Y. Zhang, J. Albero, L.F. Xi, K.M. Lange, H. Garcia, X. Wang, M. Shalom, One-pot synthesis of nickel-modified carbon nitride layers toward efficient photoelectrochemical cells, ACS Appl. Mater. Interfaces 9 (38) (2017) 32667-32677.

[90] F.J. Qi, Y.B. Li, Y.B. Wang, Y. Wang, X. Liu, X. Zhao, Ag-doped g- $\mathrm{C}_{3} \mathrm{~N}_{4}$ film electrode: fabrication, characterization and photoelectrocatalysis property, RSC Adv. 6 (84) (2016) 81378-81385.

[91] M.Y. Huang, Y.L. Zhao, W. Xiong, S.V. Kershaw, Y.G. Yu, W. Li, T. Dudka, R.Q. Zhang, Collaborative enhancement of photon harvesting and charge carrier dynamics in carbon nitride photoelectrode, Appl. Catal. B Environ. 237 (2018) 783-790.

[92] M. Zhang, X.J. Bai, D. Liu, J. Wang, Y.F. Zhu, Enhanced catalytic activity of potassium-doped graphitic carbon nitride induced by lower valence position, Appl. Catal. B Environ. 164 (2015) $77-81$.

[93] S.Z. Hu, L. Ma, J.G. You, F.Y. Li, , Z.P. Fan, G. Lu, D. Liu, J.Z. Gui, Enhanced visible light 
photocatalytic performance of $\mathrm{g}-\mathrm{C}_{3} \mathrm{~N}_{4}$ photocatalysts Co-doped with iron and phosphorus. Appl. Sur. Sci. 311 (2014) 164-171.

[94] S.Z. Hu, R.R. Jin, G. Lu, D. Liu, J.Z. Gui, The properties and photocatalytic performance comparison of $\mathrm{Fe}^{3+}$-doped $\mathrm{g}-\mathrm{C}_{3} \mathrm{~N}_{4}$ and $\mathrm{Fe}_{2} \mathrm{O}_{3} / \mathrm{g}-\mathrm{C}_{3} \mathrm{~N}_{4}$ composite catalysts, RSC Adv. 4 (7) (2014) 24863-24869.

[95] Y.R. Guo, Q. Liu, Z.H. Li, Z.G. Zhang, X.M. Fang, Enhanced photocatalytic hydrogen evolution performance of mesoporous graphitic carbon nitride Co-doped with potassium and iodine, Appl. Catal. B Environ. 221 (2018) 363-370.

[96] S.N. Guo, Y. Zhu, Y.Y. Yan, Y.L. Min, J.C. Fan, Q.J. Xu, Holey structured graphitic carbon nitride thin sheets with edge oxygen doping via photo-fenton reaction with enhanced photocatalytic activity. Appl. Catal. B Environ. 185 (2016) 315-321.

[97] Y.P. Zhu, T.Z. Ren, Z.Y. Yuana, Mesoporous phosphorus-doped g- $\mathrm{C}_{3} \mathrm{~N}_{4}$ nanostructured flowers with superior photocatalytic hydrogen evolution performance, ACS Appl. Mater. Interfaces 7 (30) (2015) 16850-16856.

[98] S.C. Yan, Z.S. Li, Z.G. Zou, Photodegradation of rhodamine B and methyl orange over boron-doped g- $\mathrm{C}_{3} \mathrm{~N}_{4}$ under visible light irradiation, Langmuir 26 (6) (2010) 3894-3901.

[99] H.J. Yu, L. Shang, T. Bian, R. Shi, G.I.N. Waterhouse, Y.F. Zhao, C. Zhou, L.Z.Wu, C.H. Tung, T.R. Zhang, Nitrogen-doped porous carbon nanosheets templated from $\mathrm{g}-\mathrm{C}_{3} \mathrm{~N}_{4}$ as metal-free electrocatalysts for efficient oxygen reduction reaction, Adv. Mater. 28 (25) (2016) 5080-5086.

[100] J.X. Low, J.G. Yu, M. Jaronie, S. Wageh, A.A. Al-Ghamdi, Heterojunction photocatalysts, Adv. Mater. 29 (20) (2017) 1601694.

[101] M.Y. Zhang, H.L. Lin, J. Cao, X.M. Guo, S.F. Chen, Construction of novel S/CdS Type II heterojunction for photocatalytic $\mathrm{H}_{2}$ production under visible light: The intrinsic positive role 
of elementary Alpha-S. Chem. Eng. J. 321 (2017) 484-494.

[102] M.G. Lee, D.H. Kim, W. Sohn, H. Park, S. Lee, H.W. Jang, Conformally coated BiVO nanodots on porosity-controlled $\mathrm{WO}_{3}$ nanorods as highly efficient type II heterojunction photoanodes for water oxidation, Nano Energ, 28 (2016) 250-260.

[103] J.X. Low, C.J. Jiang, B. Cheng, S. Wageh, A.A. Al-Chamdi, J.G. Yu, A review of direct Z-scheme photocatalysts, Small Methods 1 (5) (2017) 1700080.

[104] H.J. Li, W.G. Tu, Y. Zhou, Z.G. Zou, Z-scheme photocatalytic systems for promoting photocatalytic performance: recent progress and future challenges, Adv. Sci. 3 (11) (2016) 1500389.

[105] J.G. Hou, C. Yang, Z. Wang, Q.H. Ji, Y.T. Li, G.C. Huang, S.Q. Jiao, H.M. Zhu, Three-dimensional Z-scheme $\mathrm{AgCl} / \mathrm{Ag} /$ gamma-TaON heterostructural hollow spheres for enhanced visible-light photocatalytic performance, Appl. Catal. B Environ. 142 (2013) 579-589.

[106] P. Szymanski, M.A. El-Sayed, Some recent developments in photoelectrochemical water splitting using nanostructured $\mathrm{TiO}_{2}$ : a short review, Theor. Chem. Acco. 131 (6) (2012) 1202.

[107] Z.D. Li, C.H. Yao, Y.H. Yu, Z.Y. Cai, X.D. Wang, Highly efficient capillary photoelectrochemical water splitting using cellulose nanofiber-templated $\mathrm{TiO}_{2}$ photoanodes. Adv. Mater. 26 (14) (2014) 2262-2267.

[108] M.V. Sheridan, D.J. Hill, B.D. Sherman, D.G. Wang, S.L. Marquard, K. R. Wee, J.F. Cahoon, T.J. Meyer, All-in-one derivatized tandem $\mathrm{p}^{+} \mathrm{n}$-silicon- $\mathrm{SnO}_{2} / \mathrm{TiO}_{2}$ water splitting photoelectrochemical cell, Nano Lett. 17 (4) (2017) 2440-2446.

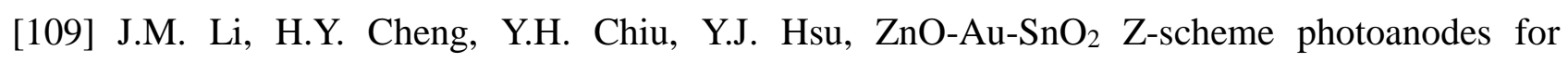
remarkable photoelectrochemical water splitting, Nanoscale 8 (34) (2016) 15720-15729. 
[110] K. Li, Z.Y. Huang, X.Q. Zeng, B.B. Huang, S.M. Gao, J. Lu, Synergetic effect of Ti ${ }^{3+}$ and oxygen doping on enhancing photoelectrochemical and photocatalytic properties of $\mathrm{TiO}_{2} / \mathrm{g}-\mathrm{C}_{3} \mathrm{~N}_{4}$ heterojunctions, ACS Appl. Mater. Interfaces 9 (13) (2017) 11577-11586.

[111] A.P. Singh, P. Arora, S. Basu, B.R. Mehta, Graphitic carbon nitride based hydrogen treated disordered titanium dioxide core-shell nanocatalyst for enhanced photocatalytic and photoelectrochemical performance, Int. J. Hydrogen. Energ. 41 (13) (2016) 5617-5628.

[112] S.C. Han, Y.C. Pu, L.F. Zheng, L.F. Hu, J.Z. Zhang, X.S. Fang, Uniform carbon-coated CdS core-Shell nanostructures: synthesis, ultrafast charge carrier dynamics, and photoelectrochemical water splitting, J. Mater. Chem. A 4 (3) (2016) 1078-1086.

[113] J.Y. Zhang, Y.H. Wang, J. Jin, J. Zhang, Z. Lin, F. Huang, J.G. Yu, Efficient visible-light photocatalytic hydrogen evolution and enhanced photostability of core/shell $\mathrm{CdS} / \mathrm{g}-\mathrm{C}_{3} \mathrm{~N}_{4}$ nanowires, ACS Appl. Mater. Interfaces 5 (20) (2013) 10317-10324.

[114] Z.M. Zhang, C.T. Gao, Z.M. Wu, W.H. Han, Y.L. Wang, W.B. Fu, X.D. Li, E.Q. Xie, Toward efficient photoelectrochemical water-splitting by using screw-like $\mathrm{SnO}_{2}$ nanostructures as photoanode after being decorated with CdS quantum dots, Nano Energ. 19 (2016) 318-327.

[115] Z.S. Li, Z.S. Liu, B.L. Li, D.H. Li, C.Y. Ge, Y.P. Fang, Novel CdS nanorods/g-C $\mathrm{N}_{4}$ nanosheets 1-D/2-D hybrid architectures: an in situ growth route and excellent visible light photoelectrochemical performances, Mater. Sci Mater. Electron. 27 (3) (2016) 2904-2913.

[116] R.N. Wang, J. Yan, M. Zu, S.Y. Yang, X. Cai, Q.Z. Gao, Y.P. Fang, S.S. Zhang, S.Q. Zhang, Facile synthesis of interlocking $\mathrm{g}-\mathrm{C}_{3} \mathrm{~N}_{4} / \mathrm{CdS}$ photoanode for stable photoelectrochemical hydrogen production, Electrochim. Acta 279 (2018) 74-83.

[117] L. Yang, Y.L. Xiong, W.L. Guo, J.N. Guo, D. Gao, Y.H. Zhang, P. Xiao, Mo ${ }^{6+}$ doped $\mathrm{BiVO}_{4}$ with improved charge separation and oxidation kinetics for 
photoelectrochemical water splitting, Electrochim. ACTA 256 (2017) 268-277.

[118] S.C. Wang, P. Chen, J.H. Yun, Y.X. Hu, L.Z Wang, An electrochemically treated $\mathrm{BiVO}_{4}$ photoanode for efficient photoelectrochemical water splitting, Angew. Chem. Int. Edi. 56 (29) (2017) 8500-8504.

[119] J. Cheng, X.L. Yan, Q.H. Mo, B.T. Liu, J. Wang, X. Yang, L. Li, Facile synthesis of g- $\mathrm{C}_{3} \mathrm{~N}_{4} / \mathrm{BiVO}_{4}$ heterojunctions with enhanced visible light photocatalytic performance, Ceram. Int. 43 (1) (2017) 301-307.

[120] Z.H. Zhang, M. Wang, W.Q. Cui, H. Sui, Synthesis and characterization of a core-shell $\mathrm{BiVO}_{4} @ \mathrm{~g}-\mathrm{C}_{3} \mathrm{~N}_{4}$ photo-catalyst with enhanced photocatalytic activity under visible light irradiation, RSC Adv. 7 (14) (2017) 8167-8177.

[121] Y.L. Tian, B.B. Chang, Z.C. Yang, B.C. Zhou, F.N. Xi, X.P. Dong, Graphitic carbon nitride- $\mathrm{BiVO}_{4}$ heterojunctions: simple hydrothermal synthesis and high photocatalytic performances, RSC Adv. 4 (8) (2014) 4187-4193.

[122] Y. Wang, J.Y. Sun, J. Li, X. Zhao, electrospinning preparation of nanostructure $\mathrm{g}-\mathrm{C}_{3} \mathrm{~N}_{4} / \mathrm{BiVO}_{4}$ composite films with an enhanced photoelectrochemical performance, Langmuir 33 (19) (2017) 4694-4701.

[123] C.C. Feng, Z.H. Wang, Y. Ma, Y.J. Zhang, L. Wang, Y.P. Bi, Ultrathin graphitic $\mathrm{C}_{3} \mathrm{~N}_{4}$ nanosheets as highly efficient cocatalyst for water oxidation, Appl. Catal. B Environ. 205 (2017) 19-23.

[124] T.T. Xiao, Z. Tang, Y. Yang, L.Q. Tang, Y. Zhou, Z.G. Zou, In situ construction of hierarchical $\mathrm{WO}_{3} / \mathrm{g}-\mathrm{C}_{3} \mathrm{~N}_{4}$ composite hollow microspheres as a Z-scheme photocatalyst for the degradation of antibiotics, Appl. Catal. B Environ. 220 (2018) 417-428.

[125] X.J. She, J.J. Wu, H. Xu, J. Zhong, Y. Wang, Y.H. Song, K.Q. Nie, Y. Liu, Y.C. Yang, M.T.F. 
Rodrigues, R. Vajtai, J. Lou, D.L. Du, H.M. Li, P.M. Ajayan, High efficiency photocatalytic water splitting using 2D alpha- $\mathrm{Fe}_{2} \mathrm{O}_{3} / g-\mathrm{C}_{3} \mathrm{~N}_{4}$ Z-scheme catalysts, Adv. Energ. Mater. 7 (17) (2017) 1700025

[126] J.Q. Li, H. Yuan, Z.F. Zhu, Improved photoelectrochemical performance of Z-scheme g- $\mathrm{C}_{3} \mathrm{~N}_{4} / \mathrm{Bi}_{2} \mathrm{O}_{3} / \mathrm{BiPO}_{4}$ heterostructure and degradation property, Appl. Sur. Sci. 385 (2016) $34-41$.

[127] J.Q. Li, H.J. Hao, Z.F. Zhu, Construction of g- ${ }_{3} \mathrm{~N}_{4}-\mathrm{WO}_{3}-\mathrm{Bi}_{2} \mathrm{WO}_{6}$ double Z-scheme system with enhanced photoelectrochemical performance, Mater. Lett. 168 (2016) 180-183.

[128] Z.Y. Huang, X.Q. Zeng, K. Li, S.M. Gao, Q.Y. Wang, J. Lu, Z-scheme $\mathrm{NiTiO}_{3} / g-\mathrm{C}_{3} \mathrm{~N}_{4}$ heterojunctions with enhanced photoelectrochemical and photocatalytic performances under visible LED light irradiation, ACS Appl. Mater. Interfaces 9 (47) (2017) 41120-41125.

[129] J.H. Oh, T.G. Deutsch, H.C. Yuan, H.M. Branz, Nanoporous black silicon photocathode for $\mathrm{H}_{2}$ production by photoelectrochemical water splitting, Energ. Environ. Sci. 4 (5) (2011) $1690-1694$.

[130] Z.X. Jin, Z.F. Hu, J.C. Yu, J.F. Wang, Room temperature synthesis of a highly active $\mathrm{Cu} / \mathrm{Cu}_{2} \mathrm{O}$ photocathode for photoelectrochemical water splitting, J. Mater. Chem. A 4 (36) (2016) $13736-13741$.

[131] T.M. Suzuki, S. Saeki, K. Sekizawa, K. Kitazumi, N. Takahashi, T. Morikawa, Photoelectrochemical hydrogen production by water splitting over dual-functionally modified oxide: $p$-type $\mathrm{N}$-doped $\mathrm{Ta}_{2} \mathrm{O}_{5}$ photocathode active under visible light irradiation, Appl. Catal. B Environ. 202 (2017) 597-604.

[132] X.Z. Ma, J.T. Zhang, B. Wang, Q.G. Li, S. Chu, Hierarchical $\mathrm{Cu}_{2} \mathrm{O}$ foam $/ \mathrm{g}-\mathrm{C}_{3} \mathrm{~N}_{4}$ photocathode for photoelectrochemical hydrogen production, Appl. Sur. Sci. 427 (2018) 
907-916.

[133] X.T. Xu, Y.Z. Liu, Y.Z. Zhu, X.B. Fan, Y. Li, F.B. Zhang, G.L. Zhang, W.C. Peng, Fabrication of a $\mathrm{Cu}_{2} \mathrm{O} / \mathrm{g}-\mathrm{C}_{3} \mathrm{~N}_{4} / \mathrm{WS}_{2}$ triple-layer photocathode for photoelectrochemical hydrogen evolution, Chemelectrochem 4 (6) (2017) 1498-1502.

[134] Y.M. Dong, Y.M. Chen, P.P. Jiang, G.L. Wang, X.M. Wu, R.X. Wu, A novel g- $\mathrm{C}_{3} \mathrm{~N}_{4}$ based photocathode for photoelectrochemical hydrogen evolution, RSC Adv. 6 (9) (2016) $7465-7473$

[135] Y.P. Hou, Y.Y. Gan, Z.B. Yu, X.X. Chen, L. Qian, B.G. Zhang, L.R. Huang, J. Huang, Solar promoted Azo Dye degradation and energy production in the bio-photoelectrochemical system with a $\mathrm{g}-\mathrm{C}_{3} \mathrm{~N}_{4} / \mathrm{BiOBr}$ heterojunction photocathode, J. Power Sources, 371 (2017) 26-34.

[136] F. Yang, M. Lublow, S. Orthmann, C. Merschjann, T. Tyborski, M. Rusu, S. Kubala, A. Thomas, R. Arrigo, M. Haevecker, T. Schedel-Niedrig, Metal-free photocatalytic graphitic carbon nitride on $p$-Type chalcopyrite as a composite photocathode for light-Induced hydrogen evolution, Chemsuschem, 5 (7) (2012) 1227-1232.

[137] A. Paracchino, V. Laporte, K. Sivula, M. Graetzel, E. Thimsen, Highly active oxide photocathode for photoelectrochemical water reduction, Nat. Mater. 10 (6) (2011) 456-461.

[138] Q. Huang, Z. Ye, X.D. Xiao, Recent progress in photocathodes for hydrogen evolution, J. Mater. Chem. A 3 (31) (2015) 15824-15837.

[139] S.Y. Zhang, G.W. She, S.Y. Li, L.X. Mu, W.S. Shi, Si-H induced synthesis of $\mathrm{Si} / \mathrm{Cu}_{2} \mathrm{O}$ nanowire arrays for photoelectrochemical water splitting, Nanotech. 29 (3) (2018) 035601.

[140] J. Chen, S.H. Shen, P.H. Guo, M. Wang, P. Wu, X.X. Wang, L.J. Guo, In-situ reduction synthesis of nano-sized $\mathrm{Cu}_{2} \mathrm{O}$ particles modifying $\mathrm{g}_{-} \mathrm{C}_{3} \mathrm{~N}_{4}$ for enhanced photocatalytic 
hydrogen production, Appl. Catal. B Environ. 152 (2014) 335-341.

[141] P. Meng, M. Wang, Y. Yang, S. Zhang, L.C. Sun, CdSe quantum dots/molecular cobalt catalyst co-grafted open porous $\mathrm{NiO}$ film as a photocathode for visible light driven $\mathrm{H}_{2}$ evolution from neutral water, J. Mater. Chem. A 3 (37) (2015) 18852-18859.

[142] L. Tong, A. Iwase, A. Nattestad, U. Bach, M. Weidelener, G. Goetz, A. Mishra, P. Baeuerle, R. Amal, G.G. Wallace, A.J. Mozer, Sustained solar hydrogen generation using a dye-sensitised $\mathrm{NiO}$ photocathode/BiVO 4 tandem photo-electrochemical device, Energ. Environ. Sci. 5 (11) (2012) 9472-9475.

[143] M.A. Gross, C.E. Creissen, K.L. Orchard, E. Reisner, Photoelectrochemical hydrogen production in water using a layer-by-layer assembly of a $\mathrm{Ru}$ dye and $\mathrm{Ni}$ catalyst on $\mathrm{NiO}$, Chem. Sci. 7 (8) (2016) 5537-5546.

[144] Y.Y. Han, X.L. Lu, S.F. Tang, X.P. Yin, Z.W. Wei, T.B. Lu, Metal-free 2D/2D heterojunction of graphitic carbon nitride/graphdiyne for improving the hole mobility of graphitic carbon nitride, Adv. Energ. Mater. 8 (16) (2018) 1702992.

[145] S. Zhang, P.C. Gu, R. Ma, C.T. Luo, T. Wen, G.X. Zhao, W.C. Cheng, X.K. Wang, Recent developments in fabrication and structure regulation of visible-light-driven $\mathrm{g}-\mathrm{C}_{3} \mathrm{~N}_{4}$-based photocatalysts towards water purification: A critical review, Catal. Today (2018) DOI: 10.1016/j.cattod.2018.09013.

[146] G. Zhao, H.C. Yang, M.Q. Liu, X.J. Xu, Metal-free photocatalyst of graphitic carbon nitride goes into two-dimensional time, Front. Chem. (2018) DOI: 10.3389/fmats.2017.00011.

[147] W.W. Han, Z. Li, Y. Li, X.B. Fan, F.B. Zhang, G.L. Zhang, W.C. Peng, The promoting role of different carbon allotropes cocatalysts for semiconductors in photocatalytic energy generation and pollutants degradation, Front. Chem. 5 (2017) 84. 
[148] W.J. Ong, 2D/2D Graphitic carbon nitride $\left(\mathrm{g}-\mathrm{C}_{3} \mathrm{~N}_{4}\right)$ heterojunction nanocomposites for photocatalysis: Why does face-to-face interface matter? Front. Mater. 4 (2017) 11.

[149] X. Shi, H. Jeong, S.J. Oh, M. Ma, K. Zhang, J. Kwon, I.T. Choi, I.Y. Choi, H.K. Kim, J.K. Kim, J.H. Park, Unassisted photoelectrochemical water splitting exceeding 7\% solar-to-hydrogen conversion efficiency using photon recycling, Nat. Commun. 7 (2016) 11943.

[150] D.K. Lee, D. Lee, M.A. Lumley, K. S. Choi, Progress on ternary oxide-based photoanodes for use in photoelectrochemical cells for solar water splitting, Chem. Soc. Rev. (2018) DOI:10.1039/c8cs00761f.

[151] S.S. Yi, X.B. Zhang, B.R. Wulan, J.M. Yan, Q. Jiang, Non-noble metals applied to solar water splitting, Ener. Envir. Sci. 11 (11) (2018) 3128-3156.

[152] S.S. Song, Y.Y. Guo, T.Y. Peng, J. Zhang, R.J. Li, Effects of the symmetry and carboxyl anchoring group of zinc phthalocyanine derivatives on $\mathrm{g}-\mathrm{C}_{3} \mathrm{~N}_{4}$ for photosensitized $\mathrm{H}_{2}$ production, RSC Adv. 6 (81) (2016) 77366-77374.

[153] W. Che, W.R. Cheng, T. Yao, F.M. Tang, W. Liu, H. Su, Y.Y. Huang, Q.H. Liu, J.K. Liu, F.C. Hu, Z.Y. Pan, Z.H. Sun, S.Q. Wei, Fast photoelectron transfer in $\left(\mathrm{C}_{\text {ring }}\right)-\mathrm{C}_{3} \mathrm{~N}_{4}$ plane heterostructural nanosheets for overall water splitting, J. Amer. Chem. Soc. 139 (8) (2017) 3021-3026.

[154] Y.X. Zeng, X. Liu, C.B. Liu, L.L. Wang, Y.C. Xia, S.Q. Zhang, S.L. Luo, Y. Pei, Scalable one-step production of porous oxygen-doped $\mathrm{g}-\mathrm{C}_{3} \mathrm{~N}_{4}$ nanorods with effective electron separation for excellent visible-light photocatalytic activity, Appl. Catal. B Envir. 224 (2018) 1-9.

[155] L.B. Jiang, X.Z. Yuan, Y. Pan, J. Liang, G.M. Zeng, Z.B. Wu, H. Wang, Doping of graphitic 
carbon nitride for photocatalysis: A review, Appl. Catal. B Envir. 217 (2017) 388-406.

[156] B.C. Zhu, L.Y. Zhang, B. Cheng, J.G. Yu, First-principle calculation study of tri-s-triazine-based g-C $\mathrm{C}_{3} \mathrm{~N}_{4}$ : a Review, Appl. Catal. B Environ. 224 (2018) 983-999.

[157] G.S Shanker, R. Bhosale, S. Ogale, A. Nag, 2D nanocomposite of $\mathrm{g}-\mathrm{C}_{3} \mathrm{~N}_{4}$ and TiN embedded $\mathrm{N}$-doped graphene for photoelectrochemical reduction of water using sunlight, Adv. Mater. Interfaces, (2018) DOI: 10.1002/admi.2018.01488.

[158] L. Jing, W.J. Ong, R. Zhang, E. Pickwell-MacPherson, J.C. Yu, Graphitic carbon nitride nanosheet wrapped mesoporous titanium dioxide for enhanced photoelectrocatalytic water splitting, Catal. Today 315 103-109.

[159] Z.F. Liu, X. Lu, Multifarious function layers photoanode based on $\mathrm{g}-\mathrm{C}_{3} \mathrm{~N}_{4}$ for photoelectrochemical water splitting, Chin. J. Catal. 39 (9) (2018) 1527-1533.

[160] D.Q. Zeng, P.Y. Wu, W.J. Ong, B.S. Tang, M.D. Wu, H.F. Zheng, Y.Z. Chen, D.L. Peng, Construction of network-like and flower-like $2 \mathrm{H}-\mathrm{MoSe}_{2}$ nanostructures coupled with porous g- $\mathrm{C}_{3} \mathrm{~N}_{4}$ for noble-metal-free photocatalytic $\mathrm{H}_{2}$ evolution under visible light, Appl. Catal. B Envir. 233 (2018) 26-34.

[161] Z.Z Kong, X.Z. Chen, W.J. Ong, X.J. Zhao, N. Li, Atomic-level insight into the mechanism of 0D/2D black phosphorus quantum dot/graphitic carbon nitride (BPQD/GCN) metal-free heterojunction for photocatalysis, Appl. Sur. Sci. 464 (2019) 1148-1153.

[162] X.Z. Chen, X.J. Zhao, Z.A Kong, W. J. Ong, N. Li, Unravelling the electrochemical mechanisms for nitrogen fixation on single transition metal atom embedded in defective graphitic carbon nitride, J. Mater. Chem. A 6 (2018) 21941-21948.

[163] D.Q. Zeng, W.J. Ong, Y.Z. Chen, S.Y. Tee, C.S. Chua, D.L. Peng, M.Y. Han, Co2P nanorods as an efficient cocatalyst decorated porous $\mathrm{g}-\mathrm{C}_{3} \mathrm{~N}_{4}$ nanosheets for photocatalytic hydrogen 
production under visible light irradiation, Part. Part. Syst. Charact. 35 (2018) 1700251.

[164] L.C. Liu, A. Corma, Metal catalysts for heterogeneous catalysis: from single atoms to nanoclusters and nanoparticles, Chem. Rev. 118 (10) (2018) 4981-5079.

[165] J.H. Peng, X.Z. Chen, W. J. Ong, X. J. Zhao, N. Li, Surface and heterointerface engineering of 2D MXenes and their nanocomposites: insights into electro- and photocatalysis, Chem (2018) DOI: 10.1016/j.chempr.2018.08037.

[166] B. Han, R. Lang, B.T. Qiao, A.Q. Wang, T. Zhang, Highlights of the major progress in single-atom catalysis in 2015 and 2016, Chin. J. Catal. 38 (9) (2017) 1498-1507.

[167] Y.J. Chen, S.F. Ji, C. Chen, Q. Peng, D.S. Wang, Y.D. Li, Single-atom catalysts: synthetic strategies and electrochemical applications, Joule 2 (7) (2018) 1242-1264. 